LORRAINE JOHNS

\title{
RECOGNISING NON-CONJUGAL RELATIONSHIPS \\ IN NEW ZEALAND: \\ SHOULD WE EXTEND THE RIGHTS AND \\ RESPONSIBILITIES OF MARRIAGE AND \\ MARRIAGE-LIKE RELATIONSHIPS TO OTHER \\ CARING RELATIONSHIPS?
}

\section{LLM RESEARCH PAPER}

LAWS 591: THESIS

FACULTY OF LAW

TE WHARE WÁNANGA O TE ŨPOKO O TE IKA A MĀUI

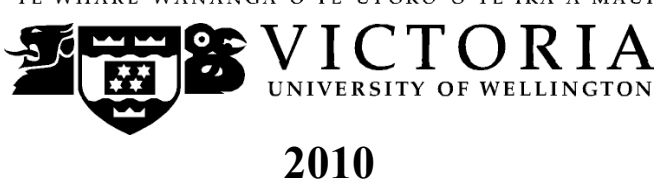




\section{Table of Contents}

\section{Chapter One}

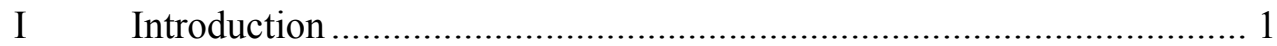

II Structure of Thesis....................................................................... 4

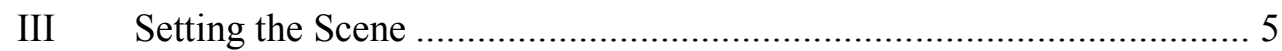

A What Are Non-Conjugal Relationships? ........................................... 6

B The Legal Recognition of Non-Conjugal Relationships: Why is This an Important Issue? ................................................................. 8

C The Demographics of Non-Conjugal Relationships: How Common Are They? .......................................................................... 9

D Examples of Non-Conjugal Relationships Already Recognised by New Zealand Law ........................................................................12

E Recognising Non-Conjugal Relationships - the Human Rights

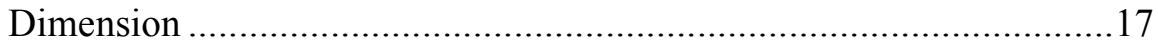

IV Principles for Recognising Personal Relationships ............................18

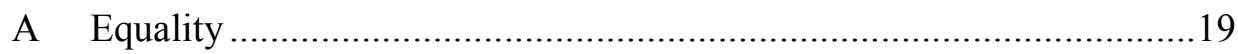

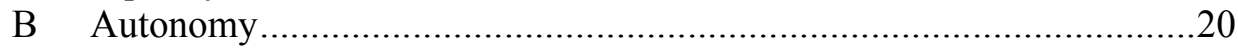

C Other Important Principles ........................................................2

1 Personal security and protecting the vulnerable ...............................21

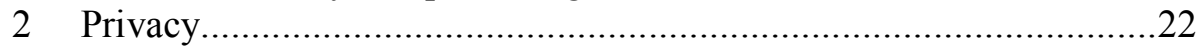

3 Religious freedom and freedom of conscience .............................23

4 The protection of reasonable expectations ......................................23

5 Other principles of good policy design: efficiency, coherence and

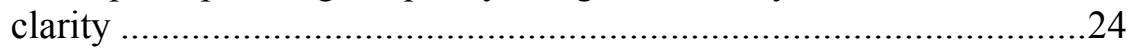

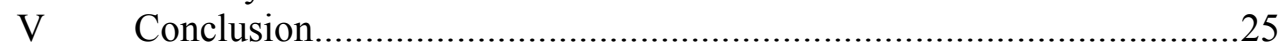

\section{Chapter Two}

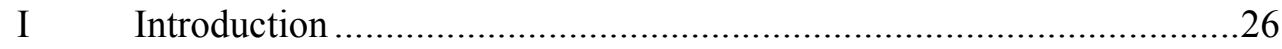

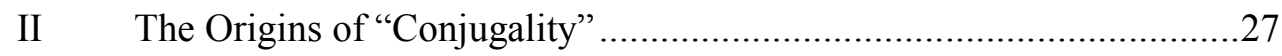

III Marriage and Conjugality ........................................................27

A Historical Social and Legal Understandings of Marriage .....................28

B Contemporary Social Understandings of Marriage ..............................29

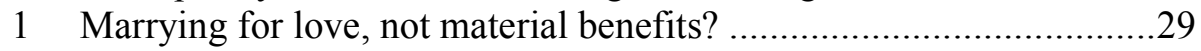

2 Marriage as the quintessential relationship? .................................31

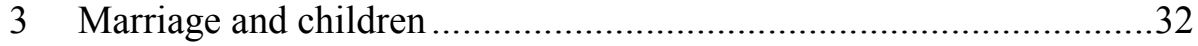

C The Contemporary Legal Approach to Marriage .................................33

IV Conjugality and the Social Sciences................................................34

A The Contribution of Philosophy - Conjugal Love as Unique.................35

1 Autonomy as freedom to pursue the Good........................................35

2 Being valued underpins our desire to pursue the Good .....................36

3 Conjugal love has unique value because it is exclusive.....................37

4 Critique of Bennett's account of conjugal love ................................39

B The Importance of Support Networks and Companionship...................41

V Burden v United Kingdom ..........................................................42

A Background: The Civil Partnership Act 2004 (UK) ............................43

B The Facts of Burden v United Kingdom...........................................44

C Arguments by the Parties ..........................................................4 
1 The Burden sisters' argument....................................................44

2 The United Kingdom's response ................................................45

D Decision of the European Court of Human Rights at First Instance ......46

1 The majority Judges.....................................................................46

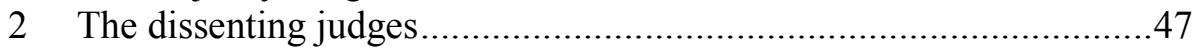

E Decision of the Grand Chamber on Appeal .....................................48

1 The majority judges .............................................................48

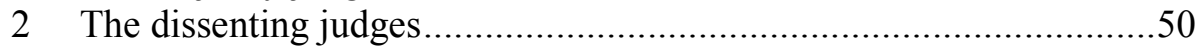

F Burden v United Kingdom: Concluding Thoughts............................50

VI De Facto Relationships: The Legal Test for Conjugality .....................51

A What is Marriage-Like Like? ............................................................52

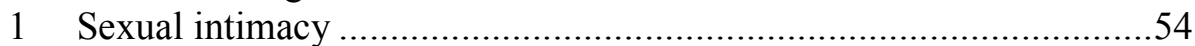

2 Commitment to a shared life and living together as a couple .............56

3 Conclusion - destablisation of the conceptual divide between conjugality and non-conjugality ...............................................58

VII The State's Interest in Recognising a Wider Range of Personal

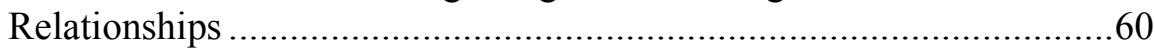

VIII Non-Conjugal Relationships as Family Relationships .......................61

IX Conclusion............................................................................63

Chapter Three

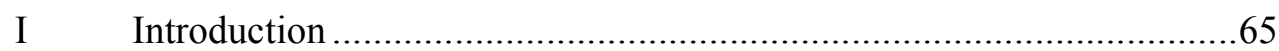

II Models for Recognising Relationships ........................................66

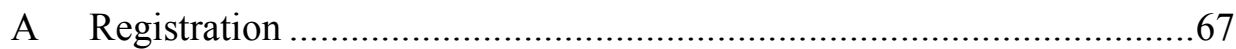

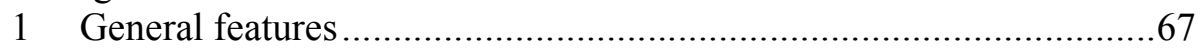

2 Registration and non-conjugal relationships ................................69

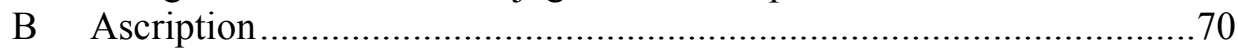

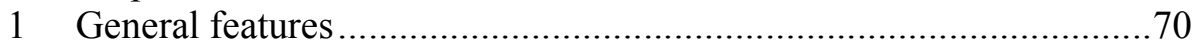

2 Ascription and non-conjugal relationships...................................72

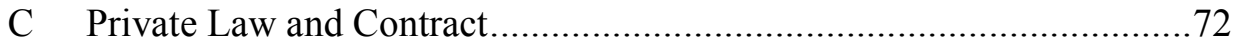

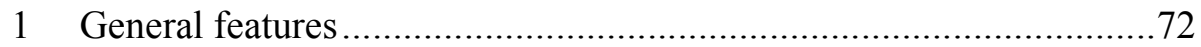

2 Private contract and non-conjugal relationships............................75

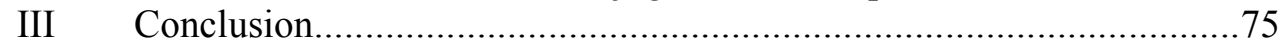

Chapter Four

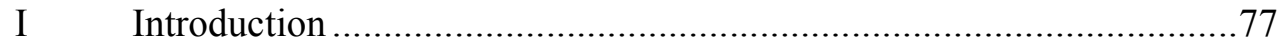

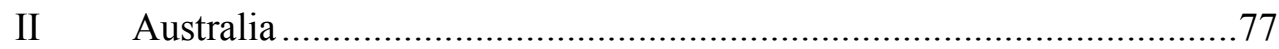

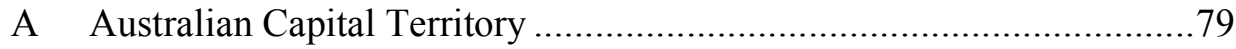

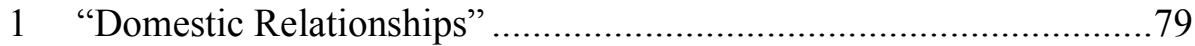

2 Application of relationship recognition principles ..........................80

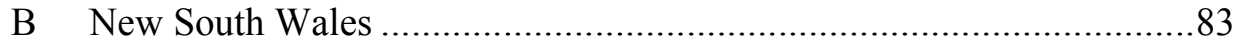

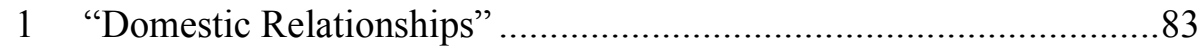

2 Application of relationship recognition principles .........................85

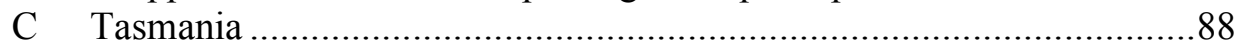

1 "Significant" and "caring relationships".......................................88

2 Application of relationship recognition principles ......................... 90

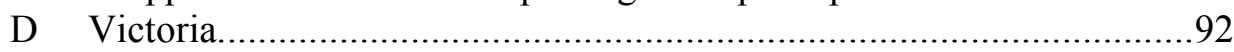

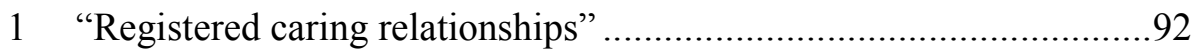

2 Application of relationship recognition principles .........................94 


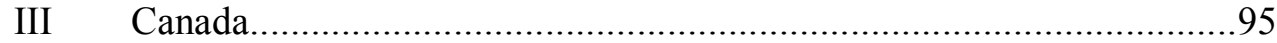

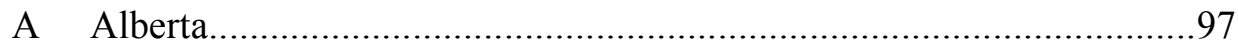

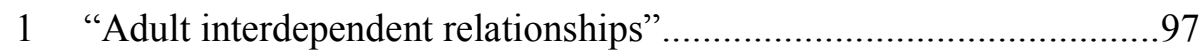

2 Application of relationship recognition principles ............................99

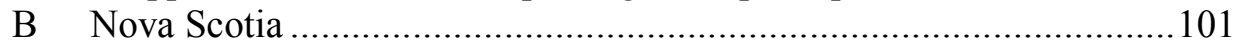

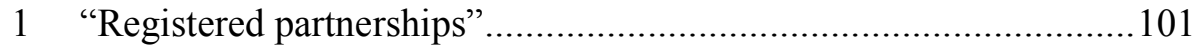

2 Application of relationship recognition principles ………..................103

IV United States of America ............................................................... 104

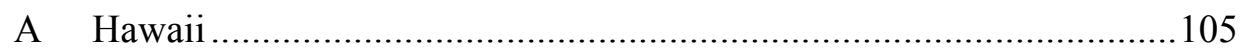

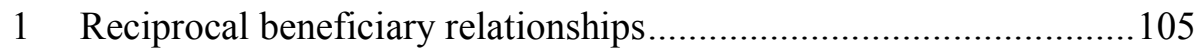

2 Application of relationship recognition principles ............................106

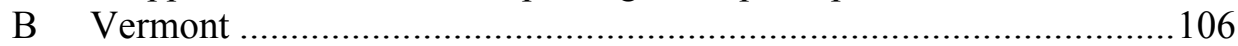

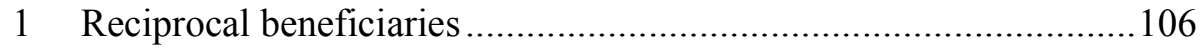

2 Application of the relationship recognition principles.......................109

$\mathrm{V}$ Other Overseas Examples of the Recognition of Non-Conjugal

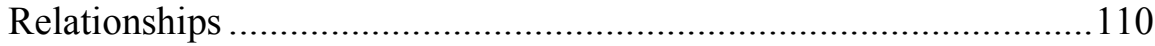

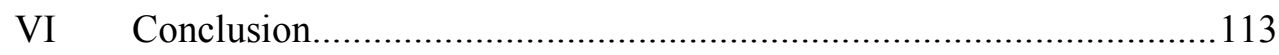

\section{Chapter Five}

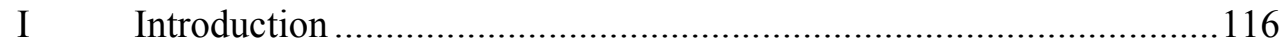

II The Disadvantages of Extending the Marriage Model .........................117

A Defeating the Expectations of Non-Conjugal Relationships ................118

B Meeting the Specific Needs of those in Non-Conjugal

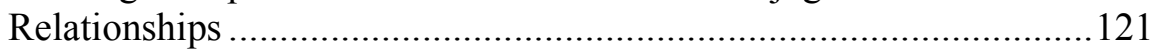

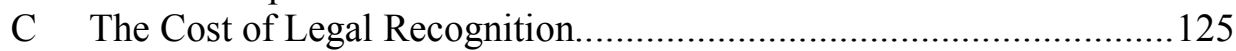

D Impact on Equality between Conjugal Relationships...........................125

E Concerns about Polygamous or Incestuous Relationships....................126

F The Plight of the Burden Sisters: Responses other than Comprehensive Recognition Based on the Marriage Model ...............128

G Conclusions as to the Merits of Extending the Marriage Model to Include Non-Conjugal Relationships..................................................129

III Case Study: Recognising Relationships between Informal Carers and Disabled Adults in New Zealand ..............................................132

A Atkinson v Ministry of Health.......................................................... 132

B The Needs of Informal Caregivers ………………..........................134

IV The Relevance of Non-Conjugal Relationships to the Law..................135

V Proposed Framework for Recognising Relationships...........................138

A Family Provision: Family Protection Act 1955 ....................................140

B Intestacy: Administration Act 1969................................................. 143

C Bereavement and Sick Leave: Holidays Act 2003 ..............................144

D Joint Family Homes: Joint Family Homes Act 1964............................147

E Domestic Violence: Domestic Violence Act 1995................................150

F Pensions: New Zealand Superannuation and Retirement Income

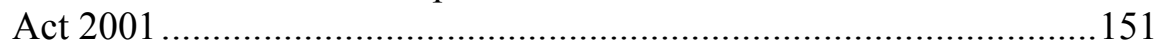

G Fatal Accidents: Accident Compensation Act 2001 .............................152

H Summing Up: The Significance of Fiscal Implications.........................153

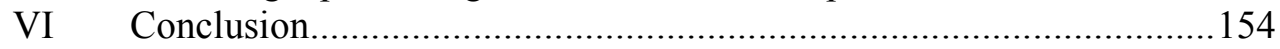

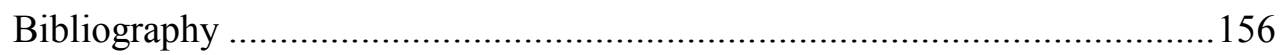




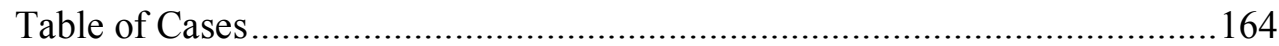

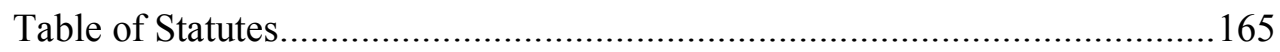




\section{Abstract}

This thesis considers whether the legal recognition of non-conjugal relationships in New Zealand should be improved; particularly by extending them the rights and responsibilities of marital and marriage-like (conjugal) relationships. For the purpose of this thesis, "non-conjugal" relationships are close, caring platonic relationships where people share their lives to a significant degree.

Over the last decade, there has been a trend toward extending the legal consequences of marriage to non-conjugal relationships in countries such as Australia, Canada and the United States. At the same time, the distinction between conjugal and non-conjugal relationships has been destabilised, due to the de-emphasis of sexual intimacy as a criterion for recognising marriage-like relationships.

This thesis considers whether the marriage model should be extended to include certain non-conjugal relationships in New Zealand, as it has been overseas. It is clear that non-conjugal relationships can exhibit many of the features associated with conjugal relationships, as demonstrated by the high profile Burden sisters' case in the United Kingdom. These include characteristics such as long-term cohabitation, caring, commitment and interdependency. However, non-conjugal relationships typically exhibit these features to a lesser degree, which means that they may have different needs and require different support from the state.

Ultimately, this thesis recommends against extending the marriage model to non-conjugal relationships for a number of reasons, including that the marriage model does not appear to respond adequately to the needs or living arrangements of people in non-conjugal relationships. However, this thesis also suggests that non-conjugal relationships in New Zealand can benefit from legal recognition in some cases. Aside from human rights considerations, the state has an interest in promoting these relationships due to their contribution to social cohesion and informal caregiving. As such, this thesis recommends a new framework for recognising personal relationships that also allows for nonconjugal relationships in New Zealand to be supported and promoted by the law, where appropriate.

\section{Word length}

The text of this paper (excluding abstract, table of contents, footnotes and bibliography) comprises approximately 46,722 words.

\section{Subjects and Topics}

Marriage - De facto relationships

Conjugal relationships

Non-conjugal relationships

Family Law - New Zealand

Human rights - New Zealand Bill of Rights Act 1990

Legal models - Comparative approaches

Burden v United Kingdom (2006) 21 BHRC 640 (Section IV, ECHR)

Burden v United Kingdom (2008) 47 EHRR 857 (Grand Chamber, ECHR). 


\section{CHAPTER ONE: INTRODUCTION TO NON-CONJUGAL RELATIONSHIPS AND LEGAL PRINCIPLES FOR RECOGNISING PERSONAL RELATIONSHIPS}

\section{Introduction}

Joyce and Sybil have been together for many years. They live in the English countryside, in a house they jointly own. They describe their relationship as caring, sharing, committed and interdependent. In fact, they consider their relationship as much of an expression of self-determination and personal development as if they were joined in marriage. Their expectation is of a lifelong partnership.

Given this, each woman, in the event that she might be the one who dies first, has willed her share of their home to the other. This is a common legal arrangement among married couples. However, unlike a widow, the surviving woman will be subject to a crippling inheritance tax bill under British law. To pay this bill, she will be forced to sell the family home.

Joyce and Sybil consider this inequitable and a breach of their human rights. For this reason, in the words of the $B B C$, the two women, "...have written to the Chancellor of the Exchequer the day before every Budget since 1976, pleading for recognition under the tax rules as a cohabiting couple."1

Earlier this decade, it appeared that the women's pleas might be answered through the Civil Partnership Bill (UK). This Bill was amended in 2004 by the House of Lords to extend many of the rights and obligations of married couples to same-sex cohabitees in Joyce and Sybil's position (including an exemption from inheritance tax). ${ }^{2}$ However, at the penultimate moment, this amendment was removed by the House of Commons, even though the

\footnotetext{
1 “Q\&A: The Burdens' inheritance tax” BBC News (London, 29 April 2008).

2 (22 April 2004) 662 GBPD HL 1362.
} 
fundamental purpose of the Bill was to address inequities between married and same-sex couples. ${ }^{3}$

Why? Because Joyce and Sybil are not a same-sex couple in the ordinary sense of these words. They are sisters. The purpose of the deleted amendment was to allow long-term cohabiting siblings, such as Joyce and Sybil Burden, to enter into a civil partnership in the same way that a same-sex couple can now do so under the Civil Partnership Act 2004.

The Burden sisters enjoy what is known as a "non-conjugal" relationship. The term "non-conjugal relationship" is used by academics and legal commentators to refer to adult personal relationships that are platonic, but are, nonetheless, very close. Non-conjugal relationships can include relationships such as those between adult siblings, an adult child and their parent, extended family members, or two very close friends who have lived together for many decades and share their lives to a significant degree. The term is therefore adopted in this thesis.

In contrast, a "conjugal" relationship is essentially a marital or marriagelike relationship. In New Zealand, marriage-like relationships are civil unions entered into under the Civil Union Act 2004, or de facto relationships, which are also recognised by the law. The idea that the law should treat two siblings the same as it treats married couples is fairly novel and has not been considered by lawmakers in New Zealand. However, in parts of Australia, Canada and the United States of America, the law has been reformed to recognise relationships like that between the Burden sisters in a similar way to married couples.

This recent trend is said to reflect the fact that non-conjugal relationships are so important to our wellbeing that the law rightly affords them the same privileges as it affords to conjugal relationships. They are important because they exhibit the same desirable features we associate, ideally, with conjugal relationships. For example, emotional and financial support, caring and commitment. This raises the question of what support people in non-conjugal

\footnotetext{
${ }^{3}$ (12 October 2004) 425 GBPD HC 251.
} 
relationships should receive from the state and whether such relationships should be supported and promoted in the same way as conjugal relationships.

New Zealand has not experienced a test case similar to that of the Burden sisters and conjugality remains a key means of demarcating relationships for an array of legal purposes. However, New Zealand already affords some limited legal recognition to close non-conjugal relationships, such as for the purposes of domestic violence. These instances, while discrete, respond to a recognised need for the state to support a wider range of personal relationships than simply those that are conjugal.

But are these measures sufficient? What legal problems do people in non-conjugal relationships face? What criteria are used to decide which of our personal relationships should be recognised? Are these criteria appropriate in a free and democratic society? What are the options for recognising non-conjugal relationships and what sort of non-conjugal relationships should be recognised? Can even friendship have legal consequences? The purpose of this thesis is to consider whether New Zealand law should recognise non-conjugal relationships in the same way that it recognises conjugal relationships. ${ }^{4}$ It seeks to determine whether people in conjugal relationships enjoy legal privileges that should be extended to other caring relationships.

Ultimately this thesis argues against recognising non-conjugal relationships in the same way as marriage or marriage-like relationships, either by allowing non-conjugal relationships to be registered for this purpose or by imposing rights and obligations on non-conjugal relationships. The marriage model was not designed to apply to non-conjugal relationships and does not appear well suited to what is known of the needs and living arrangements of people in most non-conjugal relationships. However, this thesis also considers

\footnotetext{
${ }^{4}$ Conjugal relationships include both marriage and marriage-like relationships (civil unions and de facto relationships). Note that in New Zealand there are a few outstanding areas where marriage is treated differently from marriage-like relationships, such as adoption and the laws of evidence. See Dean R Knight "State of the (Civil) Union: Assessing the Legal Significance of the Civil Union Act 2004 and Relationships Bill 2005" (paper presented to Lesbian and Gay Archives New Zealand Conference, Wellington, December 2006), but see Re AMM \& KJO HC Wellington CIV 2010-485-328, 17 May 2010, where the High Court ruled that unmarried heterosexual couples could adopt under the Adoption Act 1955.
} 
whether the law should treat non-conjugal relationships differently than it currently does, and if so, how and for what purposes?

This thesis concludes that the Burden sisters' case has shown that it is unfair to treat non-conjugal relationships differently from conjugal relationships for certain legal purposes, though not necessarily for all legal purposes. However, New Zealand does not have an overall policy that clearly signals why or when one personal relationship should be treated differently from another. For this reason, this thesis proposes a new framework to assist policymakers to identify what relationships are relevant when undertaking law reform that affects our personal relationships. This will ensure that non-conjugal relationships receive appropriate legal recognition.

\section{Structure of Thesis}

This thesis advances an argument for better legal recognition of nonconjugal relationships on the basis that a distinction between conjugal and nonconjugal relationships cannot always be justified and that non-conjugal relationships should also be supported and promoted by the state. To develop this argument, the thesis is structured as follows.

Chapter One introduces the topic and explores why we might ask questions about the legal recognition of non-conjugal relationships. It then proposes some core criteria for assessing schemes for recognising close personal adult relationships, based primarily on those proposed in a report on the recognition of non-conjugal relationships by the Law Commission of Canada. $^{5}$ It is suggested that these criteria should guide the development of future laws that affect close personal adult relationships.

Chapter Two develops an understanding of the concepts of conjugality and non-conjugality, drawing on both legal and social science perspectives. The chapter focuses on exploring the use of conjugality as a legal marker for recognising relationships. It is impossible to understand non-conjugality without first understanding conjugality, as the two concepts are in binary

\footnotetext{
${ }^{5}$ Law Commission of Canada Beyond Conjugality: Recognizing and supporting close personal adult relationships (2001) at 13 .
} 
opposition, and non-conjugality would not exist without conjugality. As part of this discussion, this chapter also considers the Burden sisters' case and how the state benefits from the formation and maintenance of a variety of close personal relationships.

Chapter Three introduces the legal models that are used to recognise close personal relationships.

Chapter Four canvasses and critiques a range of overseas approaches to comprehensively recognising non-conjugal relationships.

Chapter Five considers whether the marriage model in New Zealand should be extended to include non-conjugal relationships, concluding that, on balance, it should not be extended. However, it is suggested that there are areas in which New Zealand law could better recognise non-conjugal relationships for particular purposes. The chapter concludes by proposing alternative options for reform, in particular, the establishment of a new framework to assist policymakers determine which personal relationships are relevant to a particular law.

The Burden sisters' real-life situation is referred to throughout this thesis as a practical example of an important non-conjugal relationship to ground discussion and test analysis and proposals.

\section{Setting the Scene}

What has been driving legal commentators and legislatures in countries such as Canada and Australia to support extending legal recognition to nonconjugal relationships on a similar basis as to marriage? This introductory chapter sets out some of the basic matters that underlie this inquiry. This includes some preliminary information about the Burden sisters' case, other examples of legal issues that those in non-conjugal relationships might face, some examples of where New Zealand law already recognises non-conjugal relationships and some demographic information about non-conjugal relationships. 
One of the conclusions that this chapter draws is that there is limited demographic information available about non-conjugal relationships, mainly because population censuses are not designed to gather this information. However, despite the lack of information, there are compelling reasons to consider whether non-conjugal relationships should receive increased legal recognition.

This chapter also identifies a set of fundamental principles to guide the recognition of personal relationships in New Zealand. It adopts the principles suggested by the Law Commission of Canada in its seminal report Beyond Conjugality, ${ }^{6}$ with some adjustments. This report aims to provide a comprehensive and principled approach to the legal recognition of close personal relationships (including both conjugal and non-conjugal relationships).

\section{A What Are Non-Conjugal Relationships?}

At first glance, non-conjugal relationships do not appear similar to conjugal relationships. Non-conjugal relationships are diverse and can include relationships between senior citizens, adult children with their parents, adult siblings, friends, caregivers, extended family members or people who share a home (other than spouses or partners). There are even documented cases of boarders living with older couples for many decades and legal disputes arising from this sustained period of intimate living. ${ }^{7}$

As a lengthy period of cohabitation would suggest, non-conjugal relationships of interest to the law also tend to involve a significant degree of closeness or intimacy. This, in turn, may reflect the presence of certain other characteristics, such as emotional and financial interdependency or caring and commitment. If we look again at the situation of Joyce and Sybil Burden, we can see a real example of this type of relationship and how the law impacts on it.

\footnotetext{
${ }^{6}$ Ibid.

7 See John Eekelaar and Mavis Maclean "Marriage and the Moral Bases of Personal Relationships" (2004) 31 JLS 510 at 536.
} 
Burden $v$ United Kingdom was a case that went before the European Court of Human Rights and the Grand Chamber of the Court on appeal. ${ }^{8}$ The case involved two elderly sisters (both in their late eighties) who had lived together from birth. The sisters claimed that they were discriminated against and should be treated the same way as married couples and civil union partners because they had lived together in a "committed and mutually supportive relationship, all their lives." 9

For the past thirty years the sisters had also lived in the family home which they inherited from their parents. Each sister had cared for the other and had made a will leaving all her property to the other sister. When one of the sisters died, however, under the Inheritance Tax Act 1984 (UK), the surviving sister would have to pay a tax bill of 40 per cent of the value of the deceased sister's property (at the time, this was likely to amount to a sum of over $£ 285,000$ ). It was considered likely that the surviving sister would have to sell her home in order to pay the tax.

The sisters alleged that they were discriminated against because spouses and civil partners are both exempted from inheritance tax (the latter under the Civil Partnership Act 2004), being treated as a single economic unit for inheritance tax purposes. ${ }^{10}$ In the first instance, the sisters brought a complaint before the European Court of Human Rights where judgment was delivered on 12 December 2006. ${ }^{11}$ The Court found, 4-3, in favour of the British Government. The sisters then appealed to the Grand Chamber of the European Court of Human Rights, which delivered its judgment, also in favour of the British Government, 15-2, on 29 April 2008. ${ }^{12}$ The arguments of the parties and

\footnotetext{
${ }^{8}$ Burden v United Kingdom (2006) 21 BHRC 640 (Section IV, ECHR); Burden v United Kingdom (2008) 47 EHRR 857 (Grand Chamber, ECHR).

${ }^{9}$ Burden (Grand Chamber), ibid, at 859 .

${ }^{10}$ The sisters lodged a complaint under Article 14 (freedom from discrimination) of the European Convention for the Protection of Human Rights and Fundamental Freedoms, taken in conjunction with Article 1 of Protocol No 1 (entitlement to peaceful enjoyment of possessions) of the Convention.

${ }^{11}$ Burden (Section IV), above n 8, at 656.

${ }^{12}$ Burden (Grand Chamber), above n 8, at 877.
} 
the majority and dissenting judges will be explored in Chapter Two. At this point it should be observed that, as Welstead suggests: ${ }^{13}$

The story of two unmarried elderly women, the Burden sisters, who had lived together for the whole of their lives in a loving, mutually supportive relationship and their unsuccessful application to the European Court of Human Rights (ECHR) alleging discriminatory treatment, serves as a reminder that there is one category of family members whose needs have been largely ignored by the law ... The ECHR's ruling in favour of the UK Government is a perfect illustration of the failure of the law to address the problems faced by consanguineal couples who live together in close, loyal and caring relationships. Not only do they have no recourse to most of the familial rights available to those who are married or who live with a civil partner, they are also denied many of the lesser rights given to cohabitants.

\section{B The Legal Recognition of Non-Conjugal Relationships: Why is This an Important Issue?}

The Burden sisters' case focussed on inheritance tax, but this is only one of many examples of why legal recognition may matter for non-conjugal relationships. In a report considering the recognition of non-conjugal relationships, the British Columbia Law Institute suggests that relationship status is important for a wide variety of legal matters. ${ }^{14}$ These include employment, protection of the elderly, healthcare, taxation, social assistance, compensation for personal injury upon death and other survivor benefits, insurance and wills and succession.

However, a high level description is not sufficient to understand the problems those in non-conjugal relationships such as the Burden sisters may face. Anderson expresses a concern that using "language that maintains a level of generality conceals the human dimension of the issues in question." ${ }^{\prime 2} \mathrm{He}$ suggests focusing on the specifics of individual circumstances in order to understand the defects of the law. While Anderson's comments were made primarily in relation to the exclusion of certain marriage-like relationships from

\footnotetext{
${ }^{13}$ Mary Welstead "England and Wales: The Family the Law Forgot" in Bill Atkin (ed) The International Survey of Family Law 2010 Edition (Jordans, Bristol, 2010) 113 at 113.

${ }_{15}^{14}$ British Columbia Law Institute Report on Recognition of Spousal and Family Status (1999).

15 Thomas G Anderson "Comment on the Report of the British Columbia Law Institute on Recognition of Spousal and Family Status” (2000) 12 CJWL 439 at 444.
} 
legal recognition, they are also relevant to consideration of the legal status of non-conjugal relationships.

Employment benefits are a helpful example. These benefits could include medical and dental care, pension and life insurance plans, bereavement leave, sick leave, maternity and parental leave, and leave to take care of a sick family member. But who do these financial and non-financial employment benefits cover? Imagine a scenario where, prior to retirement, one of the Burden sisters was in employment where employees could take domestic leave to take care of a sick spouse or child. Could she have taken domestic leave to take care of her sick sister if needed? Could she also have nominated her sister, rather than a spouse, to be part of an extended medical care or insurance policy, or to receive survivor benefits?

These questions are not limited to the employment sphere. For example, if one of the sisters were killed in a car accident, would the other have a right to compensation? What if an important choice was required in relation to healthcare where one sister was incapacitated and could not make a decision? What if one of the sisters had been sponsored to immigrate to and work in another country? Could the other travel with her? What if one of the sisters decided to leave the other out of her will, despite sharing a home, possessions and lives for so many decades? Such questions form the basis for the following chapters.

\section{The Demographics of Non-Conjugal Relationships: How Common Are They?}

There is little demographic information available about the nature and incidence of non-conjugal relationships. In 2006, the Irish Minister for Justice, Equality and Law Reform published an options paper on domestic partnerships which found that: ${ }^{16}$

There is very little research in Ireland or elsewhere on non-conjugal relationships ... In the absence of research material, and in view of the dearth of submissions made, the Working Group found it difficult to consider in any

\footnotetext{
${ }^{16}$ The Working Group on Domestic Partnership Options Paper (November 2006) at 57.
} 
depth the nature of the diverse relationships in this category and the options for and consequences of according legal recognition.

The paper noted, however, that the 2002 Irish Census identified 53,000 non-family households containing no related persons $(153,000$ people in total) and 39,000 non-family households containing related persons $(93,000$ people in total). ${ }^{17}$ While the precise living arrangements of people within these households were unknown, the number of non-family households, with or without related persons, was significant.

A similar picture is created by the population censuses in other jurisdictions. Barbara Stark writes of Canada that: ${ }^{18}$

A substantial minority of households involve adults living alone, lone-parent families or adults living in non-conjugal relationships. Households centred around a conjugal relationship may also include other adults with no conjugal ties to the couple, such as relatives or close friends. In addition, adult children are often returning home to live with their parents, principally for financial reasons caused by unemployment or the need to complete their education.

The concept of the economic family encompasses all relatives living in the same household, regardless of how they are related. Adult siblings living together form the largest component of this group. We know little about non-conjugal relationships between non-relatives ... Many aging baby-boomers will spend a significant part of their senior years alone. Many will live with relatives or friends in non-conjugal relationships. Increasingly, both married and unmarried adults are serving as primary caregivers for aging and infirm parents or other relatives. Many people live in extended-family households ...

The Law Commission of Canada observes that there have always been a variety of alternative family living arrangements in Canada, such as adult siblings sharing a home. ${ }^{19}$ However, the Commission notes that: ${ }^{20}$

Many non-conjugal relationships are still largely invisible in mainstream social science research. As well, we have only limited information about relationship

\footnotetext{
${ }^{17}$ Ibid.

${ }^{18}$ Barbara Stark International Family Law: An Introduction (Ashgate Publishing Limited, Hants (England), 2005) at 42.

${ }^{19}$ Law Commission of Canada Beyond Conjugality, above n 5, at ix.

${ }^{20}$ Ibid.
} 
where adults are economically, emotionally and even physically interdependent, but do not share a residence.

Similarly, there is little statistical or qualitative information about nonconjugal relationships in New Zealand. The New Zealand Population Census does not collect this information, although the Census gathers data on households. A household analysis does not capture significant relationships outside the household or the nature of the relationships between household members, such as whether their lives, finances and possessions are shared or separate. The focus of the Census is on family relationships within households, where a family is defined as a couple or a parent and a child.

Nonetheless, Statistics New Zealand has projected that one-person households will increase by 46 per cent from 333,000 in 2001 to 480,000 in 2021 and that people will be more likely to live by themselves or with people who are not their relatives. ${ }^{21}$ Relevant social patterns identified by Statistics New Zealand include changes in the rates of partnership formation (including repartnering and dissolution), the propensity of young adults to stay in the parental home, the propensity and ability of people to live alone, and the presence of other relatives (such as members of the extended family) and nonrelatives (such as boarders) in a household. ${ }^{22}$ These changes in living arrangements over time prompted Statistics New Zealand to undertake a review in 2008 which found that: ${ }^{23}$

Historically, New Zealand and international official family statistics are bound by the use of the household as the measurement entity, and the underlying family nucleus concept. It is now widely recognised that the household may be a less useful boundary for family-centred analysis and policy provision than it was in the past.

The review recommended a new framework to allow the Census to collect information on a more detailed range of family types as well as social

\footnotetext{
21 Statistics New Zealand National Family and Household Projections: 2001 (base) - 2021 Update (2005).

${ }^{22}$ Statistics New Zealand Subnational Family and Household Projections: 2006(base) - 2031 (2009).

${ }^{23}$ Statistics New Zealand Report of the Review of Official Family Statistics (2008) at 9.
} 
and economic support across households. ${ }^{24}$ The review also recommended improving definitions and the collection of data on shared living arrangements, reviewing the ability to distinguish types of social and economic support, and the development of a survey about families focused on family structure and support arrangements. However, no further work has been undertaken to date.

The limited demographic data makes it difficult to understand the nature and extent of non-conjugal relationships. It also makes it difficult to assess the potential impact of future policy changes in this area. This gap in research does not look likely to be remedied in the near future. However, as society continues to evolve and family forms diversify, with more people living in non-traditional households and a trend away from living in conjugal relationships, the need for this type of data will become more apparent. In the meantime, sociological research may offer the best source of information about non-conjugal relationships. For example, caring beyond the nuclear family has been considered by the Australian Institute of Family Studies as part of a series of articles on the needs of carers. ${ }^{25}$

\section{Examples of Non-Conjugal Relationships Already Recognised by New Zealand Law}

In overseas countries, the extension of comprehensive rights to nonconjugal relationships has taken place in environments where, prior to reform, both non-conjugal relationships and non-traditional conjugal relationships were not typically recognised by the law. ${ }^{26}$ However, New Zealand law already recognises non-conjugal relationships for particular purposes, though in some cases, this did not occur until after reform of the law relating to same-sex and de facto relationships. Some of these statutory examples are identified below.

A quick search reveals that terms such as "relative", "family", "sister", "brother", "parent" and so on occur hundreds of times on the New Zealand

\footnotetext{
${ }^{24}$ Ibid.

${ }^{25}$ Darryl Higgens "Families caring: Diverse care work of families in Australia" (2007) 76 FM 1 at 6.

${ }^{26}$ For example, legislation was passed in the Canadian province of Alberta and in Tasmania in Australia in the midst of debate on how and whether to recognise same and opposite-sex de facto relationships (although Alberta recognised heterosexual de facto relationships prior to the introduction of a registration scheme for both conjugal and non-conjugal relationships).
} 
statute book and for many different purposes. The term "relative" is often used to include many different family relationships. For example, the Human Rights Act 1993 defines "relative" as "any person who is related to the person by blood, marriage, civil union, de facto relationship, affinity or adoption; or is wholly or mainly dependent on the person; or who is a member of the person's household". ${ }^{27}$ Discrimination on this ground is illegal. A "near relative" under the Children, Young Persons, and Their Families Act 1989 means a "grandparent, aunt, uncle, brother, or sister; and includes a brother or sister of the half-blood as well as of the full-blood." 28 Section 10 of the Human Tissue Act 2008 defines "close available relative" differently depending on whether the person in question is under 16 years or not, excludes grandparents from its ambit and includes guardians of children under 16. These examples show that recognition may be limited to certain blood relatives or it may be extended to include a wider range of family members, including people not related by blood.

Definitions relating to family relationships are continually evolving in New Zealand in order to take account of changing social and cultural norms. ${ }^{29}$ The term "family" itself is an example of this trend. For example, s 4 of the Prisoners' and Victims' Claims Act 2005 defines “immediate family, in relation to a victim" as "a member of the victim's family, whanau, or other culturally recognised family group, who is in a close relationship with the victim at the time of the offence". Section 3 of the Corrections Act 2004 defines a person's family to include a person's “family group”, among other relationships. "Family group" means:

... a family group or extended family: in which there is at least one adult member with whom the person has a biological or legal relationship, or to whom the person has a significant psychological attachment; or that is the person's whanau or other culturally recognised family group.

The term "friend" also appears on the statute book, although friends are not subject to such extension recognition as traditional family members. For example, under s 18(4) of the Alcoholism and Drug Addiction Act 1966, in

\footnotetext{
${ }^{27}$ Human Rights Act 1993, s 2.

${ }^{28}$ Children, Young Persons and Their Families Act 1989, s 2.

${ }^{29}$ Families Commission Family Centred Communities (2009) at 9.
} 
ordering the release of a patient, a judge can take into account the fact that any relative or friend is willing to take care of the patient. Similarly, under s 27 of the Domestic Violence Act 1995, a relative or friend can supervise contact between a respondent and a child. Under the Mental Health Act 1993, a relative or friend can be named in a register so that they receive notice of the death of a patient under the Act as soon as practicable. In terms of the right of review of those in residential care under the Disabled Persons Community Welfare Act 1975, s 25B also allows a close relative (which includes a spouse or partner) to bring a review.

Under s 51 of the Burial and Cremation Act 1964, relatives and "friends" also have particular rights with respect to an application to remove a body from a closed cemetery to a cemetery that is not closed (anyone can apply for a licence to do so, but fees are waived for relatives and friends who do so, where a licence is granted). The term "friendship" no longer appears on the statute book, but in the past, has occurred in legislation such as the Disabled Persons Community Welfare Act 1975 (prior to repeal, former s 5 allowed grants for incorporating essential features in homes to take into account the permanency, by reason of any blood or marriage relationship or friendship or other circumstances, of any link between the disabled person and the person who was caring for him or her in the home).

Some specific legal categories of relationship have also been created to recognise close personal relationships between adults. In New Zealand, the best-known example is perhaps "domestic relationship" in the Domestic Violence Act 1995. Under this Act, a person may apply for a protection order against someone with whom they are in a domestic relationship. ${ }^{30}$ The term "domestic relationship" encompasses a wide variety of personal relationships, including people who ordinarily share a household and people who are in a "close personal relationship".31

\footnotetext{
${ }^{30}$ Domestic Violence Act 1995, s 7. A protection order is a court order made by the Family Court of New Zealand. A protection order identifies a person who has been violent and orders that they must not be violent toward the person who applied for the order or that person's children. It also prevents the person who has been violent from contacting the person who applied for the order or that person's children, unless that person agrees.

${ }^{31}$ Ibid, s 4.
} 
Section 4(3) of the Act indicates that a close personal relationship can exist between employers and employees and $\mathrm{s} 4(4)$ sets out some nonexhaustive factors that may be used to determine whether a close personal relationship exists. These include the nature and intensity of the relationship (in particular, the amount of time spent together, the places where that time is ordinarily spent and the manner in which that time is ordinarily spent) and the duration of the relationship. It also expressly provides that it is not necessary that there also be a sexual relationship. This definition of domestic relationship has some application outside of the Domestic Violence Act 1995, as it is also used with respect to conditions that may be imposed on bail under s 21 of the Bail Act 2000 (such as non-association conditions) and is referred to in s 9 of the Harassment Act $1997 .^{32}$

The New Zealand statute book also applies certain credit contract and income tax provisions to a person for whom another person "has natural love and affection". 33 For example, under the Credit Contracts and Consumer Finance Act 2003 a family trust is defined to include a trust that is established primarily to benefit "a natural person for whom the settlor has natural love and affection." Section 3 of the Coroners Act 2006 recognises the "the cultural and spiritual needs of family of, and of others who were in a close relationship to, a person who has died." The Victims Rights' Act, the Sentencing Act 2002, the Human Tissue Act 2008 and the Prisoners' and Victims' Claims Act 2005 also recognise a "close relationship".

As the examples above may suggest, the recognition of non-conjugal personal adult relationships in New Zealand is somewhat piecemeal, lacking a degree of coherence. A single right or responsibility (such as protection from domestic violence) tends to attach to a particular type of non-conjugal relationship (such as a domestic relationship), rather than a range of rights and responsibilities based on thorough consideration of the needs and obligations of

\footnotetext{
32 The Harassment Act 1997 allows a person to seek a restraining order. A restraining order legally prevents a person named in the order from contacting the person seeking the order. Protection orders and harassment orders are intended to be mutually exclusive although different criteria apply for seeking the orders.

${ }^{33}$ Credit Contracts and Consumer Finance Act 2003, s 5. See also various provisions in the Income Tax Act 2007 and the Tax Administration Act 1994.
} 
people in certain non-conjugal relationships. This contrasts with the clear and comprehensive package of rights and responsibilities that attach to marital and marriage-like relationships.

The approach taken to defining family and other relationships of friendship also appears haphazard. For example, in some cases, family is limited to blood or adoptive relationships, such as under the Family Protection Act 1955. In others, it is limited to certain classes of relatives, for example, half-siblings and uncles and aunts may be excluded even where a list is not confined to immediate family members. In other instances they are included.

Similarly, "relative" can be defined narrowly or widely. Under s 9 of the Alcoholism and Drug Addition Act 1966, "relative", in relation to an alleged alcoholic, is defined to mean a spouse, civil union partner or de facto partner; a parent, grandparent, sibling, half-sibling, child, grandchild, or step-child; or a step-parent who shares responsibility for day-to-day care of the person. However, under s 11 of the Adult Adoption Information Act 1985, relative means "a person who is by blood the grandparent, parent, child, grandchild, or (whether of the whole or half blood) brother, sister, or cousin, of that other person."

In other pieces of legislation, such as the Families Commission Act 2003 and the Children Young Persons and Their Families Act 1989, the concept of family is very diverse. For example, s 10 of the Families Commission Act states that family includes a group of people related by marriage, civil union, blood, or adoption, an extended family, 2 or more persons living together as a family, and a whanau or other culturally recognised family group. This does not mean that it is inadvisable to have differing definitions of family and other close personal relationships in different statutes. However, there does not appear to be a considered approach to deciding which definition is appropriate for a particular legal purpose. 


\section{E Recognising Non-Conjugal Relationships - the Human Rights Dimension}

The previous sections showed that while non-conjugal relationships may already be recognised by the law, they are not well recognised in national statistical data. Much of the argument in favour of recognising non-conjugal relationships relies on human rights principles.

Human rights are becoming increasingly important in family law to resolve difficult legal issues. The Burden sisters called on principles of equality before the law and British and European Human Rights legislation to support their claim. Similarly, the academic literature on recognising non-conjugal relationships points to human rights as the primary impetus for extending legal recognition to non-conjugal relationships. ${ }^{34}$ Nayar suggests that human rights are based on: ${ }^{35}$

... those components, qualitatively articulated, which are identified as the universally relevant constituents of what is understood as "human life", irrespective of the rich diversity of humanity, which when satisfied within specific social contexts give meaning to a distinctly human life.

The New Zealand Bill of Rights Act 1990 was enacted to affirm, protect, and promote human rights and fundamental freedoms in New Zealand. The Act sets out a variety of human rights that are protected. Section 19(1) provides that "Everyone has the right to freedom from discrimination on the grounds of discrimination in the Human Rights Act 1993." Section 21(1) of the Human Rights Act provides that family status is a prohibited ground of discrimination. In addition to marriage and marriage-like relationships, as mentioned above, family status also includes being a relative of a particular person. ${ }^{36}$

Calls for non-discrimination against those in both conjugal and nonconjugal relationships have accompanied the clamour for reform of the law relating to adult personal relationships. However, it should be noted that many who advocate that recognition of non-conjugal relationships should be on a par

\footnotetext{
${ }^{34}$ See generally Law Commission of Canada Beyond Conjugality, above n 5.

${ }^{35}$ R Jayakumar Nayar "Not another Theory of Human Rights" in C Gearty and A Tomkins (eds) Understanding Human Rights (Continuum, London, 2000) at 187.

${ }^{36}$ There do not appear to be any cases exploring the meaning of "relative".
} 
with conjugal relationships do not support the explicit recognition of same-sex relationships. ${ }^{37}$ Nonetheless, human rights values should underpin the recognition of personal relationships in New Zealand.

\section{Principles for Recognising Personal Relationships}

The final task for this chapter is to establish some core criteria that may be used as a basis to evaluate the recognition of close personal adult relationships (both conjugal and non-conjugal relationships). This thesis largely adopts the constitutional and human rights principles set out by the Law Commission of Canada in Beyond Conjugality. ${ }^{38}$ The Law Commission suggests that equality and autonomy are the "fundamental values [which] ought to guide the development of government policies that have an impact on close personal adult relationships. ${ }^{39}$ The Law Commission also observes that:

... there are a number of other important principles and values that must be respected in order to enhance equality and autonomy in the area of close personal adult relationships; these include personal security, privacy, freedom of conscience and religion, coherence and efficiency.

The British Columbia Law Institute also advocates a series of similar principles to guide the recognition of personal relationships in British Columbia. $^{40}$ These include the principle of voluntariness and the principle of the protection of reasonable expectations.

This thesis suggests that the two overarching principles that should guide relationship recognition are equality and autonomy. These principles should be given priority unless there are compelling reasons for prioritising others. The other important principles identified below are personal security and protection of the vulnerable; freedom of conscience, thought, and religion; the protection of reasonable expectations; and other principles of good public policy design, namely efficiency, coherence and certainty. It is inevitable that

\footnotetext{
${ }^{37}$ This observation will be explored thoroughly in Chapter Four, which considers the overseas regimes that have been established to recognise non-conjugal relationships and the rationales for establishing these schemes.

${ }^{38}$ Law Commission of Canada Beyond Conjugality, above n 5.

${ }^{39}$ Ibid, at 113 .

${ }^{40}$ British Columbia Law Institute Spousal and Family Status, above n 14, at 2-3.
} 
some of the principles identified compete with each other. Some favour individualisation, while others favour protection and equality values. Ultimately the weight accorded to each principle must be determined in the particular context.

\section{A Equality}

The Law Commission of Canada considers that equality is a basic value, enshrined in international human rights documents and the Canadian constitution. $^{41}$ Equality is also a fundamental value in the New Zealand legal system as enshrined in the rule of law and the Human Rights Act 1993. The Law Commission focuses on the following two types of equality: equality within relationships and equality between relationships. ${ }^{42}$

Equality within relationships is about power imbalances in personal relationships. For example, the subordination of women, persons with disabilities and other members of disadvantaged groups. The principle of equality within relationships aims to address unequal distributions of income, wealth and power.

Equality between relationships refers to respecting and promoting equality among different kinds of relationships. When benefits are distributed inequitably, those denied their share subsidise the recipients. ${ }^{43}$ Governments are under increasing pressure to better align the law with social realities by acknowledging and respecting the diversity of a wide variety of close personal relationships. ${ }^{44}$ However, while governments can acknowledge the existence of diverse relationships, whether they should be treated in the same way is a complicated matter.

One of the predominant issues raised in the same-sex marriage debate is whether same-sex relationships are qualitatively different from heterosexual marital relationships. Ball suggests that an understanding of equality as treating similarly those who are similarly situated cannot be applied neutrally in the

\footnotetext{
${ }^{41}$ Law Commission of Canada Beyond Conjugality, above n 5, at 13.

42 Ibid.

${ }^{43}$ British Columbia Law Institute Spousal and Family Status, above n 14, at 9.

${ }^{44}$ Law Commission of Canada Beyond Conjugality, above n 5, at 13.
} 
context of relationship recognition. ${ }^{45}$ This is because it is not possible for the state to determine whether one type of relationship is similarly situated to another without making judgements about the goodness and value of the relationships. In Quilter $v$ Attorney-General, the majority in the Court of Appeal did not consider that prohibiting same-sex couples from marrying amounted to unequal treatment, in accordance with community values. ${ }^{46}$

In practice, this idea of "sameness" is determined by having regard to the functions a relationship serves. Cossman and Ryder state that: ${ }^{47}$

Pursuant to this approach, legal decision-makers seek to identify the basic dimensions and functions of a marital relationship, and then determine whether the relationship in question has a sufficient number of these features to qualify as a conjugal or marriage-like relationship.

The drawback to this approach when it is applied as a legal test is that it requires an investigation into the intimate details of the lives of those under examination. It also tends to involve comparisons against an idealised version of the marital relationship.

Similar issues arise in determining whether non-conjugal relationships are similar to conjugal relationships, for all material purposes. If they are not then it may be undesirable to treat them in the same way, particularly where this does not lead to an equal outcome.

\section{B Autonomy}

The Law Commission of Canada suggests that autonomy is "the freedom to choose whether and with whom to form close personal relationships" and is a fundamental value in free and democratic societies. ${ }^{48}$ In this context, Karst observes that it is "the choice to form and maintain an intimate association that permits full realization of the associational values we

\footnotetext{
${ }^{45}$ Carlos A Ball “Against Neutrality in the Legal Recognition of Intimate Relationships” (2008) 9 GJGL 321 at 322.

${ }^{46}$ Quilter v Attorney-General [1998] 1 NZLR 523.

47 Brenda Cossman and Bruce Ryder "What is Marriage-Like Like? The Irrelevance of Conjugality" (2001) 18 Can J Fam L 269 at 286.

${ }^{48}$ Law Commission of Canada Beyond Conjugality, above n 5, at 13.
} 
cherish most." $" 49$ The British Columbia Law Institute calls for the protection of relationships based on personal choice and suggests that the state has a duty to avoid policies "that do not recognize people who live together as family outside of the traditional forms, or that prevent people from voluntarily assuming family rights, obligations and responsibilities among themselves."50

As this suggests, voluntariness is a key aspect of the principle of autonomy. ${ }^{51}$ In this respect, the Law Institute suggests that the law should not impose rights and obligations on people who live together unless they accept those obligations or another principle outweighs the principle of voluntariness, such as the protection of the vulnerable. ${ }^{52}$ To give effect to the principle of autonomy, laws must also be sufficiently flexible to accommodate the particular circumstances of individual relationships. ${ }^{53}$ However, flexibility in legislative design must often be traded off against coherence and clarity. Notwithstanding these concerns, the principle of autonomy requires that, unless there is good justification, people should be able to choose the people with whom they form close relationships.

\section{Other Important Principles \\ $1 \quad$ Personal security and protecting the vulnerable}

Sometimes people may be unable to protect themselves from other people with whom they have a relationship. This does not just include protection from physical violence, but may also include being subjected to economic hardship during the relationship or when it ends. States have a responsibility to support the personal security of people in relationships, including their physical, psychological and emotional security. This enhances the ability of individuals to make free and healthy choices to enter and leave relationships.

\footnotetext{
${ }^{49}$ Kenneth L Karst "The Freedom of Intimate Association” (1980) 89 Yale LJ 624 at 637. Karst identifies these as companionship, caring, commitment, intimacy and self-realisation

${ }^{50}$ British Columbia Law Institute Spousal and Family Status, above n 14, at 5.

${ }^{51}$ Ibid.

${ }^{52}$ Ibid, at 6.

${ }^{53}$ Ibid.
} 
The Law Commission of Canada suggests that states should take steps to discourage abusive relationships and protect vulnerable partners. ${ }^{54}$ Where possible, people in these relationships should be offered the same legal protections that the community has agreed are necessary in more traditional family units so that one party cannot use the absence of legal regulation to the other's detriment. In such cases the principle of voluntariness must sometimes give way to the principle of protecting the vulnerable. In this respect, Thomas observes that people do not always have an unfettered choice regarding their living arrangements (for example, they may not freely choose to cohabit rather than marry) and states should be prepared to accord recognition, where necessary, to protect the interests of people in such relationships. ${ }^{55}$

\section{$2 \quad$ Privacy}

Privacy is another fundamental value that states should have regard to when regulating close personal relationships. The Law Commission of Canada suggests that healthy personal relationships are founded on "candour and trust" and that "they can flourish only if we are confident that our intimate thoughts and acts will not be revealed to others." states should establish rules that prohibit intrusive examinations or forced disclosure of confidences, though privacy values must sometimes give way to objectives such as detecting and prosecuting crime.

It should be noted that the principle of privacy does not equate to the traditional belief that the state should not interfere in the domestic realm. Houlgate expresses this as the position that if "an area of life is believed to be private, this is expressed by saying that the law ought not to intervene and/or enforce the corresponding moral obligation." power imbalances and privilege traditional relationships over non-traditional relationships. In fact, Houlgate observes that, in reality, the state: ${ }^{58}$

\footnotetext{
${ }^{54}$ Law Commission of Canada Beyond Conjugality, above n 5, at 19.

55 Caroline A Thomas "the Roles of Registered Partnerships and Conjugality in Canadian Family Law" (2006) 22 CJFL 223 at 233.

${ }^{56}$ Law Commission of Canada Beyond Conjugality, above n 5, at 21.

${ }^{57}$ Laurence Houlgate "What is legal intervention in the family? Family law and family privacy" (1998) 17 Law and Phil 141 at 142.

${ }^{58}$ Ibid, at 158
} 
... intervenes with a power-conferring or defining function of family law whenever it defines a pre-existing social practice, for example, as when the state imposes its own conditions and consequences of marriage on a previous existing religious or social practice of marriage.

The Law Commission of Canada suggests that religious freedom and freedom of conscience should also be considered guiding principles. Freedom of thought, conscience, and religion are enshrined in s 13 of the New Zealand Bill of Rights Act 1990, which provides that "everyone has the right to freedom of thought, conscience, religion, and belief, including the right to adopt and hold opinions without interference." Section 13 should also be reflected in policies regarding the legal recognition of personal relationships. Section 7 requires that where a Bill appears to be inconsistent with the Bill of Rights, the AttorneyGeneral must "bring to the attention of the House of Representatives any provision in the Bill that appears to be inconsistent with any of the rights and freedoms contained in this Bill of Rights."

\section{$4 \quad$ The protection of reasonable expectations}

The Law Commission of Canada does not consider the role of reasonable expectations in the design of relationship recognition schemes. However, the British Columbia Law Institute suggests that "one function of the law is to protect people's reasonable expectations" with respect to how the law will treat their relationship. ${ }^{59}$ The Law Institute recommends that the law be required to protect reasonable expectations, so that it does not recognise some non-traditional relationships and not others, or else risk losing its legitimacy and force.

As a corollary, it is also important not to legislate against reasonable expectations by imposing rights and responsibilities on people who do not want or expect to be subject to them. Sometimes principles such as equality, autonomy and protecting the vulnerable may require an outcome that is unfavourable to one of the parties in a relationship. However, it might be suggested that, in such cases, such expectations may not be reasonable.

\footnotetext{
${ }^{59}$ British Columbia Law Institute Spousal and Family Status, above n 14, at 7.
} 

clarity

The Law Commission of Canada also advocates efficiency and coherence as two important principles underlying the recognition of personal relationships. ${ }^{60}$ These principles should inform the development of legal models for recognising relationships because they, along with the values identified above, are at the heart of modern policy design. Stone suggests that "... policy is the rational attempt to attain objectives." $" 61$ Stone identifies the central concepts of modern policy analysis as equity, efficiency, security and liberty, concepts which may be understood as goals as well as justifications, criteria, and standards.

The Law Commission suggests that efficiency, in the context of relationship recognition, requires that the policy reach the intended beneficiaries. $^{62}$ Efficiency also allows for the assessment of the merits of different ways of doing things and involves assessing how burdens and benefits are distributed, how we measure the value and costs of a policy, and what mode of organising human activity is likely to yield the most efficient results. ${ }^{63}$ There are fiscal implications of extending rights relating to state support to a wider group of people. However, some rights and obligations do not require the allocation of scarce resources, such as protection from domestic violence.

Coherence requires that laws for recognising relationships have clear objectives and that there is consistency between policies. The Law Commission observes that "If the objectives of laws are not clear, or the design of laws does not line up with their stated objectives, then laws lack coherence". ${ }^{64}$ It is also important that laws are certain so that people can assess whether and how a particular law impacts on their situation.

\footnotetext{
${ }^{60}$ Law Commission of Canada Beyond Conjugality, above n 5, at 21.

${ }^{61}$ Deborah Stone Policy Paradox: The Art of Political Decision Making $\left(2^{\text {nd }}\right.$ ed, Norton \& Company, New York, 2002) at 37.

${ }^{62}$ Law Commission of Canada Beyond Conjugality, above n 5, at 21.

${ }^{63}$ Stone, above n 61 , at 38.

${ }^{64}$ Law Commission of Canada Beyond Conjugality, above n 5, at 23.
} 


\section{Conclusion}

This chapter set out to introduce the concept of non-conjugality and why non-conjugal relationships are relevant to the law, despite a lack of demographic information about their nature and incidence. It also advanced a set of principles, based on human rights values, to guide discussion about the recognition of non-conjugal relationships in the following chapters. In sum, these principles suggest that people should be at liberty to determine their own living arrangements, at least where this aligns with legitimate state objectives and support systems in place. In turn, the law should support them in doing so. This thesis now turns to explore the concepts of conjugality and nonconjugality, and the use of conjugality as a legal marker. 


\section{CHAPTER TWO: UNDERSTANDING CONJUGALITY AND NON-CONJUGALITY}

\section{Introduction}

Considerable legal consequences can hinge on the distinction that is made between conjugal and non-conjugal relationships, as has been highlighted by the Burden sisters' plight and the substantial tax bill that one of the sisters will eventually be required to pay. In considering this distinction, conjugality must be the initial focus of this chapter, as without conjugality, non-conjugality would not exist. However, defining conjugality is not an easy task. Cossman and Ryder write that: ${ }^{1}$

Given the heavy legal freight the notion of conjugality has been asked to bear, one would think it would have been thoroughly investigated and its meaning clearly understood. Yet, while debates have raged over the question of who the law should consider to be a spouse, the definition of conjugality remains elusive.

Cossman and Ryder suggest that the difficulty with understanding conjugality is that the "presence or absence of a sexual component to a relationship has become immaterial to, or of declining relevance in, identifying conjugal relationships" and that this has led to an "increasing instability of the distinction between conjugal and non-conjugal relationships.",

This chapter explores social and legal understandings of conjugality; in particular, how the law conceptualises conjugality through the institution of marriage as well as marriage-like relationships. The chapter starts by considering the origins of the term, the social and legal understandings of marriage and how the social sciences distinguish conjugal relationships from close non-conjugal relationships. The chapter then considers the case of Burden $v$ United Kingdom ${ }^{3}$ and the legal criteria used to identify de facto relationships

\footnotetext{
1 Brenda Cossman and Bruce Ryder "What is Marriage-Like Like? The Irrelevance of Conjugality" (2001) 18 Can J Fam L 269 at 269.

${ }^{2}$ Ibid, at 270.

3 Burden v United Kingdom (2006) 21 BHRC 640 (Section IV, ECHR); Burden v United Kingdom (2008) 47 EHRR 857 (Grand Chamber, ECHR).
} 
in New Zealand, exploring how these could also apply to a non-conjugal relationship. The chapter concludes that there is a basis for requiring that certain non-conjugal relationships be considered when lawmakers are developing laws that will affect personal relationships.

\section{The Origins of "Conjugality"}

Conjugality began as a narrow concept that referred to marriage or sex within a marriage. Bieliauskas writes that "If we try to look for a precise definition of conjugal love, we find that etymologically these two concepts describe the phenomenon of love in marriage." Similarly, the Oxford English Dictionary Online defines "conjugal" as "of or relating to marriage, matrimonial" or "of or pertaining to husband or wife in their relations to each other." It also defines the verb "conjugalize" as "to marry" and notes that term "conjugalism" occurred in 1823 in a magazine article entitled "Conjugalism, or

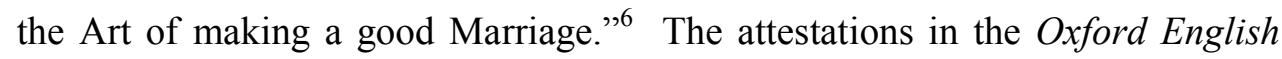
Dictionary also allude to the idea that conjugal relationships are of a special nature, for example, referring to conjugal rights as "the privilege which husband and wife have of each other's society, comfort, and affection."7

\section{Marriage and Conjugality}

Historically, marriage "has been regarded as the cornerstone of family life and thus as the basis for numerous ascribed rights and duties." ${ }^{\prime 8}$ Marriage is used to structure tax systems and allocate social welfare benefits, among other important matters. However, marriage was not originally a legal institution and neither the state nor religion played a role in marriage. ${ }^{9}$ Understandings of marriage have changed over time and between cultures. ${ }^{10}$ This section briefly sets out historical and contemporary social and legal understandings of

\footnotetext{
${ }^{4}$ Vytautus J Bieliauskas "Masculinity, Femininity, and Conjugal Love" (2005) $10 \mathrm{~J}$ of Rel and Health 37 at 43 .

${ }^{5}$ Oxford English Dictionary Online < oed.com $>$.

${ }^{6}$ Ibid.

${ }^{7}$ Ibid.

${ }^{8}$ Milton C Regan Alone Together: Law and the Meanings of Marriage (Oxford University Press, New York, 1999) at 10.

${ }^{9}$ Henry Finlay To Have But Not To Hold: A History of Attitudes to Marriage and Divorce in Australia 1858-1975 (The Federation Press, Sydney, 2005) at 4-5.

${ }^{10}$ Frank Flaspohler “All who live in love" (2009) 11 Loy J Pub Int L 87 at 90-91.
} 
marriage. It does this to show how marriage is an institution in a state of change and how social norms are not currently reflected in the legal criteria for entering into a legal marriage in New Zealand. It also shows that the concept of conjugality has become more complicated as understandings of personal relationships such as marriage have changed.

\section{A Historical Social and Legal Understandings of Marriage}

Initially, laws regulating marriage were designed by and for the privileged classes and focused on "possessions and succession to property". 11 Eekelaar suggests that the institution inherited by common law countries was centred on providing a means to secure wealth and political power, ensuring that bloodlines remained legitimate and allowing men to retain control of women. ${ }^{12}$ A woman was absorbed into her husband's legal personality, and, unable to contract in her own right, became economically dependent. This dependency was reinforced by the establishment of legal rules that favoured men in the event of separation, effectively "obliterating" a woman's freedom. ${ }^{13}$

English common law understood a husband and wife to be one person. Women had no separate legal identity from their husbands and could not enter into a contract, own property or money or bring a lawsuit. A wife was required to provide services and labour for her husband and obey him. Marital rape was not a crime. The common law allowed a husband to seek "restitution of conjugal rights". ${ }^{4}$ This refers to the law's ability to order a wife who has left her husband to return to the matrimonial bed. ${ }^{15}$ At the same time marriage was also understood as an "elevated ideal", and likened to "the type of relationship described by Aristotle and others as full friendship."16 Full friendship is not contingent on these matters, but rather on wanting the Good for the other

\footnotetext{
${ }^{11}$ Henry Finlay, above $\mathrm{n} 9$, at 5.

12 John Eekelaar Family Law and Social Policy ( $1^{\text {st }}$ ed, Weidenfeld \& Nicholson, London, 1989) at 5-6.

${ }^{13}$ Ibid, at 40 .

14 This petition was used in early New Zealand legislation, including s 16 of the Matrimonial Proceedings Act 1963 (repealed).

${ }^{15}$ Only a husband could claim this remedy. However, in the 1900 s a wife was able to cite it as grounds for divorce. See Matyasevic v Matyasevic [1965] NZLR 15 at 22.

${ }^{16}$ Eekelaar Family Law, above n 12, at 40. Originally, however, women were not considered capable of "full friendship".
} 
person. ${ }^{17}$ Eekelaar suggests that full friendship is motivated by altruism and not moral obligation. ${ }^{18}$

However, Eekelaar considers that this understanding of marriage was rarely manifested in the legal rules regulating marriage. ${ }^{19}$ He suggests that the "legal immunities between spouses conferred by the old common law ... had nothing to do with the ideals of friendship, and everything to do with male domination. ${ }^{, 20}$ Polikoff agrees that the legal rules relating to marriage may not necessarily reflect a particular social understanding of the institution. ${ }^{21}$

\section{B Contemporary Social Understandings of Marriage}

$1 \quad$ Marrying for love, not material benefits?

There is no doubt that social attitudes toward marriage have changed in contemporary times in New Zealand and other comparable countries. This is a consequence of events such as the women's liberation and human rights movements, and the shift away from a fault-based approach to family law. These changes have also affected understandings of conjugality, as conjugality can no longer simply be equated to marriage.

Parker writes of two major transformations in cultural and material values "that have driven many of the changes that have impacted on the institution of marriage. ${ }^{22}$ These saw marriage transform from an economic and political institution in which romantic love was considered of secondary importance (if not completely irrelevant) to a relationship of companions, "the companionate marriage", characterised by emotion and sentiment.

Parker suggests that the emergence of love as the primary reason to marry began in the seventeenth century, when the authority of parents and governments was somewhat displaced by the influence of spouses, lovers and friends. According to Parker, the second transformation began in the 1960s and

\footnotetext{
${ }^{17}$ Ibid.

${ }^{18}$ Ibid, at 36.

${ }^{19}$ Ibid, at 41 .

${ }^{20}$ Ibid, at 45.

${ }^{21}$ Nancy Polikoff, "We Will Get What We Ask For: Why Legalizing Gay and Lesbian Marriage Will Not Dismantle the Legal Structure of Gender in Every Marriage" (1993) 79 Va L Rev 1535 at 1611.

${ }^{22}$ Robyn Parker "Perspectives on the future of marriage" (2005) 72 Family Matters 78 at 78.
} 
1970s, along with a trend toward universal education, falling birth rates and equality between men and women. Parker suggests that the measure of a marriage "increasingly became each spouse's own self-development and expression" and that this can be referred to as "individualised marriage". ${ }^{23}$ In this respect, spouses can be seen as both "separate individuals with their own distinct interests" and "members of a community who have special obligations to promote its welfare". 24

Cherlin also suggests that over the past fifty years, the practical benefits of marriage have become less relevant in the decision to marry and that this has corresponded with an increase in marriage's symbolic and social significance. ${ }^{25}$ Similarly, Regan suggests that we live in a society that emphasises emotional bonds within relationships rather than formal legal bonds. ${ }^{26}$ Giddens suggests that marriage increasingly: $:^{27}$

... refers to a situation where a social relation is entered into for its own sake, for what can be derived by each person from a sustained association with another; and which is continued only in so far as it is thought by both parties to deliver enough satisfaction for each individual to stay within it.

In this vein, Badgett undertook a study of couples that found that to marry, couples must reach a stage characterised by love, some degree of commitment and some expectation of a continuing relationship. ${ }^{28}$ Badgett $^{2}$ emphasises the importance for couples of finding the "right person" and experiencing "the spark" ${ }^{29}$ She observes that "tangible material benefits generally did not play a role in couples' decisions" and they could access these benefits, in any event, as de facto partners. ${ }^{30}$

\footnotetext{
${ }^{23}$ Ibid, at 79 .

${ }^{24}$ Regan Alone Together, above n 8, at 3.

25 A J Cherlin "The desinstitutionalization of American Marriage" (2004) 36 J Marriage and Fam 848.

${ }^{26}$ Regan Alone Together, above n 8, at 12.

27 Anthony Giddens The Transformation of Intimacy: Sexuality, Love \& Eroticism in Modern Societies (Polity Press, London, 1992) at 58.

${ }^{28}$ M V Lee Badgett When Gay People Get Married: What happens when societies legalize same-sex marriage (New York University Press, New York, 2009).

${ }^{29}$ Ibid, at 25.

${ }^{30}$ Ibid, at 29.
} 
Likewise, in a study by Eekelaar and Maclean of the reasons people choose to marry as opposed to cohabit, many of the participants found it "distasteful to discuss the choice to marry or cohabit in terms of rights" and that ideas of rights were not "prominent" in their perceptions of their relationships. ${ }^{31}$ However, the study also identified that people do marry for pragmatic reasons, such as material benefits, as well as conventional reasons, such as confirming to religious or cultural norms. Nevertheless, the symbolic status of marriage was still important and marriage had a "continuing power as a symbol of enduring rather than transitory attachment.",32

\section{$2 \quad$ Marriage as the quintessential relationship?}

Cohen states that: ${ }^{33}$

The law should clearly distinguish married couples from other personal relationships. The harder it is to distinguish married couples from other kinds of unions, the harder it is for civil society to reinforce norms of marital behaviour.

Marriage has "profound meaning and value" for "many people other than the two getting married"34 Debate surrounding the recognition of nontraditional conjugal relationships has been polarised by those who seek to displace marriage and those who wish to continue to elevate it above all other personal relationships. Badgett states that, as a "deeply rooted social and cultural institution, marriage is powerful in ways that we might not always appreciate and in ways that we cannot control.",35

Giddens suggests that marriage is the event that has an "independent effect" in completing the "fundamental nature" of a partnership. ${ }^{36}$ Similarly, Badgett observes that marriage can be understood as "the paradigm of intimate commitment". ${ }^{37}$ Marriage also has a long-standing association with religion.

\footnotetext{
${ }^{31}$ John Eekelaar and Mavis Maclean "Marriage and the Moral bases of Personal Relationships" (2004) $31 \mathrm{JL}$ and Soc'y 310 at 536.

${ }_{32}$ Badgett Same-Sex Marriage, above n 28, at 7.

${ }^{33}$ Lloyd Cohen "No-fault family law: A problematic ideology (should family law promote marriage as the ideal?" NJLJ (26 January 2007).

${ }^{34}$ Badgett Same-Sex Marriage, above n 28, at 4.

35 Ibid.

${ }^{36}$ Ibid.

${ }^{37}$ Ibid, at 7.
} 
Flasphoser suggests that, for Christianity, "the understanding of marriage is quintessential to the understanding of the divine."38 MacLeod even suggests that it is a self-evident principle "that conjugal marriage has intrinsic value, and is thus in itself a basic reason for human choice and action."39 MacLeod also claims that it is: ${ }^{40}$

... a self-evident observation that different relational arrangements display different characteristics and produce different social benefits. On this ground, states rationally distinguish between conjugal marriage and other relationships and retain for conjugal marriage a special status in the law.

This view of marriage has been discredited in recent times as a basis for privileging marriage over other relationships. However, Atkin acknowledges the social and cultural dimensions of marriage stating that priority may be given to marriage over marriage-like relationships "either for ideological and cultural reasons or because of a sense that the public commitment in marriage makes it a better bet for secure family life."

\section{$3 \quad$ Marriage and children}

Marriage has a long-standing connection to child-bearing. ${ }^{42}$ The relationship between marriage and positive outcomes for children has been the subject of much research and social commentary. ${ }^{43}$ It is not necessary for this thesis to consider the various views. However, it is noted that children are increasingly being born outside marriage and many live in non-traditional households. This trend has weakened the relationship between child rearing and marriage. As a consequence, family law is increasingly focused on the best interests of the child rather than parents' relationship status. Consequentially, while supporting children may be an important state objective, this does not necessarily justify privileging marriage above other relationships.

\footnotetext{
${ }^{38}$ Frank Flaspohler "All who live in love", above n 10, at 88.

${ }^{39}$ Adam J MacLeod "The Search for Moral Neutrality in Same-Sex Marriage Decisions" (2008) 23 BYU J of PL 1 at 59.

${ }^{40}$ Ibid, at 59.

${ }^{41}$ Bill Atkin "The legal world of unmarried couples: reflections on "de facto relationships" in recent New Zealand legislation" (2009) 39 VUWLR 793 at 794.

${ }^{42}$ Vivian E Hamilton "Family Structure, Children, and Law" (2007) 24 Wash U J L \& Pol'y 9.

${ }^{43}$ See Robin Fretwell Wilson "Evaluating marriage: does marriage matter to the nuturing of children? (Symposium: The Meaning of Marriage)" (2005) 42 San Diego L Rev 847.
} 


\section{The Contemporary Legal Approach to Marriage}

Musselman observes that American law has never recognised marriage as a sacrament or other religious construct. ${ }^{44}$ This is also the position in New Zealand even though religious organisations have traditionally had special status to officiate at marriage ceremonies. In fact, the fundamental feature of the legal model for recognising marriage in New Zealand is the prioritisation of form over substance. This means that marriages are recognised if procedural requirements are met, such as those relating to consent and capacity. A similar approach is taken in most comparable commonwealth countries, though not all. In the United Kingdom, non-consummation of a marriage can void the marriage and adultery is a ground for dissolution. ${ }^{45}$

In contrast, in New Zealand couples may marry if they comply with the requirements of the Marriage Act 1955, whether or not their marriage accords with social norms relating to marriage. For example, there is no requirement that a marriage be caring or committed, or even that it be exclusive. New Zealand restricts marriage to people aged 16 and over, prohibits marriages between close relatives (there is an extensive list of who a person cannot marry), and prohibits people from marrying more than one person at a time. Marrying couples are not required to establish that their relationship is suitable in other ways.

This is not necessarily a criticism of the legal model for recognising marriage, as this approach allows couples to voluntarily assume legal status. The point is rather that the legal approach to recognising marriages makes it difficult to compare marriages with non-conjugal relationships, without relying solely on social norms which may not apply to the legal institution. Once a couple marries they "need conform to no particular model of behaviour in order to receive the legal protections of that status". 46

\footnotetext{
44 James L Musselman "What's Love Got to Do With It? A proposal for elevating the status of marriage by narrowing its definition, while universally extending the right and benefits enjoyed by married couples" (2009) Duke J of Gender L \& Pol'y 37.

${ }^{45}$ See Rosemary Auchmuty "Beyond Couples: Burden v United Kingdom (2008) 47 EHRR 38; [2008] 2 FLR 787; Grand Chamber of the European Court of Human Rights, 29 April 2008" (2009) 17 Fem Leg Stud 205 at 206.

${ }^{46}$ Badgett Same-sex marriage, above n 28, at 8.
} 
In particular, there is a concern about comparing non-conjugal relationships to an idealised version of marriage, which marriages might not themselves attain. Feminist and post-modern narratives also highlight the danger of uncritical acceptance of the romantic discourse around marriage by setting out the reality of marriage over the course of history as a relationship used for the purposes of power and control of men over women. When the role, functions, and nature of marriage are so contested, it becomes difficult to identify a robust reference point for comparing non-conjugal relationships to marital relationships. As such, the approach taken by this chapter to defining conjugality in the law is to consider how marriage-like relationships approach conjugality.

Ultimately, as a longstanding and well-tested institution of society, marriage is a natural choice of mechanism for allocating rights and distributing resources between citizens. However, the question is whether the marriage model should be extended to apply to other relationships that fulfil a similar role, or whether these relationships should be recognised in other ways.

\section{Conjugality and the Social Sciences}

It is because conjugality and non-conjugality can be so broadly defined that an analogy between conjugal and non-conjugal relationships can, in turn, be so readily drawn by commentators. The presence or absence of a sexual relationship is considered irrelevant and characteristics such as caring, commitment, and interdependence (or dependence) are given precedence. ${ }^{47}$ These characteristics can be present in many personal relationships, whether they are conjugal or not. Such an approach leads inevitably to equating conjugal and non-conjugal relationships.

This section seeks to look beyond the bare equivalency of broad principles by drawing on the social sciences to distinguish conjugal relationships from important non-conjugal relationships. If there is a

\footnotetext{
47 See generally Cossman and Ryder "What is Marriage-Like Like?" above n 1; Caroline A Thomas "the Roles of Registered Partnerships and Conjugality in Canadian Family Law" (2006) 22 CJFL 223; Law Commission of Canada Beyond Conjugality: Recognizing and supporting close personal adult relationships (2001); British Columbia Law Institute Report on Recognition of Spousal and Family Status (1999).
} 
meaningful distinction between conjugality and non-conjugality, then it must be based on a more detailed examination of these relationships than that presented in the available legal commentary. The commentary is flawed insofar as it does not draw on, or at least critique, any perspectives offered by the social sciences. This section focuses on developing a fuller understanding of what conjugality may entail, before turning to consider how the law defines conjugality through the criteria for recognising de facto relationships.

\section{A The Contribution of Philosophy - Conjugal Love as Unique}

This discussion focuses on the viewpoint of Christopher Bennett, who, in a philosophical exercise, argues that the state is justified in promoting relationships of conjugal love due to conjugal love's unique contribution to establishing the conditions under which an individual is able to frame and pursue that individual's conception of the Good. ${ }^{48}$ Bennett's argument is informative because he seeks to distinguish conjugal love from that of family and friends by arguing that conjugal love has a unique capacity to bring about the circumstances in which an individual can have a meaningful life.

Bennett's basic proposition is made up of a series of assertions. Bennett argues that autonomy is essential for an individual's pursuit of the Good. Autonomy is not simply external freedom but includes the ability to act on that freedom. Conjugal love can promote autonomy in a manner and to an extent that friendships cannot, by bringing about conditions in which we value our lives and make use of our autonomy. This arises from the exclusive nature of conjugal love. This proposition, Bennett argues, differentiates conjugal relationships from non-conjugal relationships such as close friendships. These propositions are now considered in detail.

$1 \quad$ Autonomy as freedom to pursue the Good

The principle of liberty underpins autonomy. The importance of the principle of liberty has been established by writers such as Rawls, who prioritise

\footnotetext{
${ }^{48}$ Christopher Bennett "Liberalism, Autonomy, and Conjugal Love" (2003) 9 Res Publica 285. Bennett does not distinguish between marriage and marriage-like relationships for the purposes of his discussion of conjugal love as his argument does not rely on how relationships of conjugal love are formalised by the law.
} 
the principle of liberty above all others. ${ }^{49}$ The definition of liberty is the subject of many opposing bodies of work. However, Rawls suggests that "for the most part, this debate is not concerned with definitions at all, but rather with the relative values of the several liberties when they come into conflict." ${ }^{\text {, }}$ Rawls suggests that there is basic acceptance of the viewpoint that persons are autonomous when free from constraints to do or not do something and when this decision is protected from interference by others.

Bennett's argument goes further. He suggests that autonomy does not simply equate to external freedom, as a person can be free but lonely and lacking in self-respect, which means that they will "lose their desire to value and pursue their own projects and enjoyments" and thereby be "psychologically unable to make use of available options." ${ }^{, 51}$ Bennett suggests, therefore, that autonomy is better understood as the ability to "frame, revise and rationally pursue a conception of the good as this is necessary to value freedom."

\section{Being valued underpins our desire to pursue the Good}

Bennett then suggests that being recognised and granted importance by others, and, in particular, having the detail of our lives valued, is a deep-seated human need and that autonomy can be compromised when this does not occur. Bennett suggests that friendships generally involve choosing someone as having a certain importance because of the particular individual they are. He suggests that granting recognition to the content of a person's life and valuing it can assist them to value themselves. Bennett states that it "is this recognising, valuing, sharing of the content of the other's life that is special to intimate relationships." ${ }^{, 52}$ He suggests that: ${ }^{.53}$

A deep human need is that aspects of our lives such as our personal history, our present projects, and our character, be accepted, affirmed, granted importance by others (or by another). When this need is not met, it can be difficult to

\footnotetext{
49 John Rawls A Theory of Justice (Oxford University Press, New York, 1971) at 541-548.

${ }^{50}$ Ibid, at 201.

${ }^{51}$ Christopher Bennett "Liberalism, Autonomy, and Conjugal Love" (2003) 9 Res Publica 285 at 286-7.

${ }^{52}$ Ibid, at 289.

${ }^{53}$ Ibid, at 290.
} 
maintain our sense of the importance of what we are doing. Thus autonomy can be compromised.

Similarly, Leib suggests that friendship is "an important social relation that contributes to our integrity and our dignity" and an "indispensable component of a good life". 54 This proposition also receives support from Rawls who refers to the "social basis" of self-respect. ${ }^{55}$ Bennett suggests that this attention cannot come from anyone and needs to be reciprocated, because "for us to gain a sense of our own importance ... the person who gives us this sense must be someone we take to be important as well." ${ }^{, 56}$ Bennett acknowledges that this argument justifies state support of friendship as well as conjugal love. However, he suggests that conjugal love is unique in the way that it provides recognition.

\section{Conjugal love has unique value because it is exclusive}

Bennett considers that conjugality differs from intimate friendship because it is exclusive. ${ }^{57} \mathrm{He}$ argues that conjugal love is unique because, ideally, we are valued exclusively by one other person in a way that no-one else values us. Conjugal relations recognise the unique value of a person's life in a way that friendship does not and thus entail a much more significant relationship. Bennett suggests that the conjugal lover is concerned with the: ${ }^{58}$

... whole of your life in a way that a friend is not ... a lover has the type of concern they have for you only for you (conjugal love is exclusive).

Bennett considers that friendship differs because it is partial and not concerned with the whole of a person's life. The special type of importance attaching to conjugal relationships leads each person in the relationship to choose to take responsibility for the other as a whole on the basis of the value each attaches to the detail of the other's life. This is a responsibility that they do not assume for anyone else. Bennett suggests that conjugality is contingent on

\footnotetext{
${ }^{54}$ Ethan J Leib "Friendship and the Law" (2007) 54 UCLA 631 at 647.

${ }^{55}$ John Rawls A Theory of Justice (Oxford University Press, New York, 1971) at 178 and 541.

${ }^{56}$ Bennett "Conjugal Love", above n 51, at 290.

${ }^{57}$ Ibid, at 288.

${ }^{58}$ Ibid, at 294.
} 
choosing one and no other, over all others, and this is how it derives its unique value. Bennett states that: ${ }^{59}$

\begin{abstract}
A relationship is, amongst other things, a structure of responsibility. Through the relationships we participate in ... we are assigned duties to respect others, to look after others, to do things for others. Others have a certain claim on us by virtue of our relationship with them. In a conjugal relationship both parties to the relationship have a particular person to turn to for support, someone who, by virtue of the sort of relationship that they are having, is charged with their care and does not have anything more important to do. Furthermore, in a conjugal relationship, as distinct from a friendship, one assumes responsibility for the whole person, the whole life of one's partner.
\end{abstract}

Bennett suggests that the exclusive nature of conjugal relationships may be manifested in the exclusive sharing of significant activities such as living together, making key life-decisions together, sexual intimacy and bringing up children. He concludes that being "special for someone else affirms and recognises your sense that the things that make you a particular individual are valuable, because someone has chosen you for those things." ${ }^{\text {60 }}$ To bring his argument full circle, he suggests that it is this sense of value that underpins and sustains autonomous functioning and that conjugal relationships are instrumental to our sense of worth. It is this, he suggests, that justifies the legal privileging of conjugal relationships over other forms of intimate relationships between friends.

As such, Bennett attempts to provide a basis on which we can distinguish between the intimacy and caring provided in both conjugal and nonconjugal relationships, and to identify why conjugal relationships are so important and significant. The attraction of Bennett's argument is that it attempts to rationally articulate something that many people have long believed about conjugal relationships - that conjugal relationships are special. His argument is not circular, linked to religion or dependent on ideas of intrinsic worth. Bennett states that: ${ }^{61}$

\footnotetext{
${ }^{59}$ Ibid, at 295-6.

${ }^{60}$ Ibid, at 297-298.

${ }^{61}$ Ibid, at 193.
} 
This account of conjugal love, if on the right lines, would explain why conjugal love remains a durable ideal; why people keep trying to make it work even when the chances of success are unclear. It helps us to make sense of our overwhelming modern tendency to search for a single life-partner. The Hegelian argument therefore aims to give an account of the 'social meaning' of conjugal love: of the meaning that the marital relationship has (on its best interpretation) for its participants.

Bennett recognises that conjugal love will not promote autonomy in the absence of other favourable social conditions such as an educated, flourishing and pluralistic civil society. However, what he does suggest is that it is one of the most important institutions that the state ought to encourage.

\section{$4 \quad$ Critique of Bennett's account of conjugal love}

Bennett acknowledges that he is putting forward a "normative account of friendship and conjugal love" and that his account might be used to critique certain present-day marriage arrangements rather than confirm them. ${ }^{62} \mathrm{He}$, therefore, qualifies his argument by suggesting that the state should support marriage only so far as marriage promotes conjugal love. This proposition is impractical. Another important matter that Bennett does not address is what sort of state support this understanding of conjugal love contemplates. For example, few, if any, would suggest that a state's interest in preventing domestic violence is confined to conjugal couples. There are many other areas such as family provision legislation and conflict of interest laws that have an interest in other personal relationships. As such, Bennett's argument should be understood to provide a basis for distinguishing between conjugal and nonconjugal relationships, but not necessarily for all legal purposes.

Most likely, what Bennett refers to are financial supports. However, conjugal relationships are a well-known example of the privatisation of care, whereby couples take care of each other, with financial support depending on whether there are children of the relationship (this financial support can also be paid to carers of children other than parents). In fact, couples assume maintenance obligations toward each other when legal status attaches to their relationship. Nonetheless, there are financial advantages, such as tax

\footnotetext{
${ }^{62}$ Ibid, 287.
} 
advantages that can attach to conjugal relationships, but are not available for any non-conjugal relationships.

Perhaps, most importantly, Bennett does not explicitly address the consequences of a lack of conjugal love. Are we to understand that this compromises autonomy as it leaves people impaired in their ability to pursue their conception of the Good. Does this mean that the Burden sisters, now in their nineties, who claim that they have a significant, caring, and stable relationship, would find a conjugal relationship more fulfilling? Bennett advocates conjugal love as the ideal form of love, although he recognises that the existence of a conjugal relationship does not render a person's friendships unimportant. One of the questions this section turns to consider below is whether it is possible that a relationship such as that between the Burden sisters could be of as much value as that involving conjugal love.

Golash suggests that Bennett also does not deal with the possibility that conjugal love devalues over time given that: ${ }^{63}$

... a long history of interaction between two people who need each other's validation tends to produce less meaningful responses over time, long-term conjugal relationships are unlikely to provide autonomy-enhancing support to their participants.

Golash accepts that intimate friendships can promote autonomy but argues that it is not clear that conjugal love does so to a greater degree. Bennett acknowledges that Golash's argument is based on a: ${ }^{64}$

... psychologically acute observation of how conjugal relationships work in actual practice. In particular, she shows how tentative I need to be about the claim that underpins the second step in my argument: as I put it above, 'that those who do not have the relationship of conjugal love are more vulnerable to a loss of autonomy or will find it harder to sustain their autonomy in the face of the characteristic difficulties of human life over the long haul'.

\footnotetext{
${ }^{63}$ Deirdre Golash "Marriage, Autonomy, and the State: Reply to Christopher Bennett" (2006) 12 Res Publica 179 at 181.

${ }^{64}$ Christopher Bennett "Conjugal Love”, above n 51, at 194.
} 
Rather, Bennett suggests that the benefit of conjugal love over time relates to the structure of the relationship, that conjugal relationships have a symbolic value that is based on each partner choosing to stay with the other and care for the other in a detailed and exclusive manner. ${ }^{65}$ Insofar as this caring persists, each conjugal partner continues to affirm the other's value as a unique individual. Ultimately, Bennett emphasises the fundamental nature of conjugal relationships in terms of the degree to which they manifest these desirable characteristics, stating that: ${ }^{66}$

For the fact of conjugal love is that a person to whom you would devote yourself has chosen to - and continues to choose to - devote himself to you. This type of relationship can provide a reasonably reliable source of support and care - since one's partner takes on a responsibility to look after you in particular. But almost more important than this is the symbolism involved in his being willing to sustain this form of relationship with you. For it is this continued effort on his part that shows you that your life matters in the scheme of things since it matters to this person who matters greatly to you.

This argument is tested below, where the nature of the non-conjugal relationship existing between the Burden sisters is explored. Before this, however, this section briefly explores the concepts of companionship and support networks as important aspects of our personal relationships, regardless of whether these relationships are conjugal or not.

\section{B The Importance of Support Networks and Companionship}

Families have long been understood in terms of caregiving relationships. ${ }^{67}$ Care is labour that is essential to the smooth functioning of society and families provide emotionally, social, physical and financial care and support to family members and rely on receiving it in turn. Higgins writes that: ${ }^{68}$

\footnotetext{
${ }^{65}$ Christopher Bennett “Autonomy and Conjugal Love: Reply to Golash” (2006) 12 Res Publica 191 at 194.

${ }^{66}$ Ibid.

${ }^{67}$ Ontario Human Rights Commission The Cost of Caring: Report on the Consultation on Discrimination on the Basis of Family Status (2006) 21.

${ }^{68}$ Daryl J Higgins "Families caring: diverse care work of families in Australia" (2007) 76 Family Matters 4 at 4.
} 
'Family' is synonymous with 'caring' interdependencies. The essence of much of the dependency is not only financial ties and obligations, but also the interrelating roles of giving and receiving care: both physical, as well as emotional care and support. Caring defines what it means to be part of a family: the responsibility - and the desire - to care for those to whom we are biologically or emotionally connected.

For those people who are not in conjugal relationships, friends and families provide a particularly important source of love, companionship and support. A study by Wilson, Calsyn and Orlofsky found that the impact of sibling relationships on social support and morale in the elderly was significant for unmarried siblings, who received emotional and practical support and reciprocated such support. ${ }^{69}$ The study found that relationships between elderly sisters were particularly intimate. Personal relationships which provide a source of companionship and support are particularly important for unmarried elderly people. Friends also tend to be particularly important to older adults who may include a friend in their description of family (particularly if they are single or widowed). ${ }^{70}$

Bennett's argument should not be understood to suggest that nonconjugal relationships are unimportant or should not be supported. Rather, Bennett attempts to distinguish between the types of love and support provided in conjugal and non-conjugal relationships, suggesting that the expressive and affective attributes are present to a greater degree in conjugal relationships than in friendships. This is manifested in the different living arrangements these relationships involve. This chapter now turns to the case of the Burden sisters.

\section{Burden v United Kingdom}

The Burden sisters' case is a real example of a situation where two people in a non-conjugal relationship have sought the same legal status as conjugal couples, claiming that their relationship is analogous. The question in this case was whether the sisters' relationship was analogous to a marriage or marriage-like relationship for the purposes of inheritance tax. This required the

\footnotetext{
${ }^{69}$ J G Wilson, R J Calsyn \& J L Orlofsky “Impact of sibling relationships on social support and morale" (1994) 22 Journal of Gerontological Social Work 157.

${ }^{70}$ Law Commission of Canada Beyond Conjugality, above n 47, at 5.
} 
courts to translate social understandings of personal relationships into legal consequences. While the sisters ultimately lost their case, a minority in each division of the European Court of Human Rights found in their favour.

\section{A Background: The Civil Partnership Act 2004 (UK)}

The Civil Partnership Act 2004 (UK) was at the heart of the Burden sisters' case. In the United Kingdom, same-sex couples can register their relationships under the Civil Partnership Act 2004. During debate in the House of Lords on the Civil Partnership Bill 2002, an amendment to extend eligibility to relatives was approved 148 votes to $130 .^{71}$ The House of Commons later removed this amendment and sent the revised Bill back to the House of Lords for reconsideration, and this version was enacted. The amendment would have made civil partnerships available to family members if they were over thirty years of age, if they had cohabited for at least twelve years, and if they were not already married or in a civil partnership. It was supported by a cross-party coalition of peers and bishops.

The proposed amendment was a result of the Burden sisters' high-profile plight. The sisters had written to the Chancellor of the Exchequer ${ }^{72}$ every year since 1976 requesting that cohabiting siblings be made exempt from inheritance tax. The amendment was not passed because the Bill was considered an inappropriate legislative basis on which to address the concerns of cohabiting relatives who care for each other. In rejecting the amendment, the House of Commons considered that the Bill, in its original format, would lead to discrimination against the family and that matters such as hospital visiting and intestacy for family members were already covered in other legislation. Sympathy was expressed as to the needs of wider family members, with the acknowledgement that the position of carers was a matter which required government attention. However, the extension of a regime for marriage-like relationships was considered a wholly inappropriate response which would lead to "legal absurdities" and financial disadvantages. In contrast, one of the lobby groups responsible for the Civil Partnership Bill termed it a "wrecking

\footnotetext{
${ }^{71}$ (22 April 2004) 662 GBPD HL 1362.

72 The Chancellor of the Exchequer is the title given to the British Cabinet minister responsible for all economic and financial matters.
} 
amendment", considering that it would have undermined the Bill's purpose of providing legal status to same-sex couples. ${ }^{73}$

\section{B The Facts of Burden v United Kingdom}

The Burden sisters had lived together from birth and, for the past thirty years, in the house they inherited from their parents. Each sister had made a will leaving all her property to the other sister. When one of the sisters died, the surviving sister would have to pay a charge of 40 per cent of the value of the deceased sister's property (at the time, this was likely to amount to a sum of over $£ 285,000$ ), which the surviving sister would have to sell the house to pay.

The sisters alleged they were discriminated against because spouses and civil partners were exempt from inheritance tax (the latter under the Civil Partnership 2004), as they are treated as a single economic unit for inheritance tax purposes. ${ }^{74}$ In the first instance, the sisters brought a complaint before the fourth section of the European Court of Human Rights, where judgment was delivered on 12 December 2006. The Court found 4-3 in favour of the British Government. The sisters then appealed to the Grand Chamber of the European Court of Human Rights, which delivered its judgment, 15-2 in favour of the British Government, on 29 April 2008.

\section{Arguments by the Parties}

There was no dispute between parties as to the purpose of the inheritance tax exemption as a measure intended to support and affirm conjugal relationships. However, the parties' views differed as to whether the Burdens' relationship could be seen as equivalent to a conjugal relationship, in terms of the nature of conjugal relationships and the benefits they provide to the state.

\section{The Burden sisters' argument}

The sisters claimed that they should be treated the same way as married couples and civil union partners because the sisters had lived together in a

\footnotetext{
${ }^{73}$ Matthew Tempest "Lords send back civil partnership bill" The Guardian (24 June 2004).

${ }^{74}$ The sisters lodged a complaint under Article 14 of the European Convention for the Protection of Human Rights and Fundamental Freedoms (freedom from discrimination), taken in conjunction with Article 1 of Protocol No 1 of the Convention (entitlement to peaceful enjoyment of possessions).
} 
"committed and mutually supportive relationship, all their lives.",75 They argued that their relationship had the same qualitative features of selfdetermination, personal development, caring, long-term cohabitation and commitment as conjugal relationships and: ${ }^{.76}$

... many siblings were connected by nothing more than their common parentage ... [the sisters] had chosen to live together in a loving, committed and stable relationship for several decades, sharing their only home, to the exclusion of other partners. Their actions in so doing were just as much an expression of their respective self-determination and personal development as would have been the case had they been joined by marriage or a civil partnership.

$2 \quad$ The United Kingdom's response

The Government of the United Kingdom argued that the essence of the Burden sisters' relationship was different from that of a marriage and that they: ${ }^{77}$

... could not claim to be in an analogous situation to a couple created by marriage or civil partnership ("a couple"). The very essence of their relationship was different, because a couple chose to become connected, whereas for sisters it was an accident of birth. In choosing to become a couple by entering into a formal relationship recognised by law, the partners also made a financial commitment to each other, and agreed to give the courts powers to divide their property and to order one partner to provide for the other on separation.

However, the Burden sisters claimed that their association did not have the legal consequences they desired or would choose to take on under the Civil Partnership Act 2004 if they were not restricted from doing so by being within the prohibited degrees. The sisters argued that the only difference between their relationship and a civil partnership was that they were not lawfully entitled to have a sexual relationship. ${ }^{78}$ They did not consider this a material difference because sexual intimacy was not relevant under the Civil Partnership Act.

\footnotetext{
${ }^{75}$ Burden v United Kingdom (2008) 47 EHRR 857 (Grand Chamber, ECHR) at 859.

${ }^{76}$ Ibid, at 873 .

${ }^{77}$ Ibid at 872 .

${ }^{78}$ Burden v United Kingdom (2006) 21 BHRC 640 (Section IV, ECHR) at 653.
} 
The Government also suggested that the objective of the inheritance tax exception was to promote stable, committed conjugal relationships and that this would: ${ }^{79}$

... not be served by extending similar benefits to unmarried members of an existing family, such as siblings, whose relationship was already established by consanguinity, and recognised by law ... The difference in treatment was, moreover, proportionate, given that the applicants, as siblings, had not undertaken any of the burdens and obligations created by a legally recognised marriage or civil partnership.

The British Government also pointed to the financial implications of recognising sibling or other family living arrangements, given that the annual income from inheritance tax was significant. The sisters responded that only a small minority of adult siblings were likely to share the type of relationship that they enjoyed.

\section{Decision of the European Court of Human Rights at First Instance}

The European Court of Human Rights was called upon to settle this matter. However, at first instance, the Court did not decide whether the siblings were in a relationship analogous to marriage, because it was able to dismiss the sisters' complaint on other grounds.

\section{$1 \quad$ The majority Judges}

In delivering the majority judgment, the court recalled its previous decisions that affirmed the differences between marital and de facto relationships, but acknowledged that the Burden sisters were not free to assume the rights and obligations of marriage. However, the Court dismissed the complaint on the basis that the United Kingdom had not exceeded the wide margin of appreciation afforded to states for the purposes of tax policy and that the difference of treatment was reasonably and objectively justified. ${ }^{80}$ The Court emphasised the role of the state in striking the balance between pursuing

\footnotetext{
${ }^{79}$ Ibid, at 652.

${ }^{80}$ Ibid, at 654 .
} 
tax revenue and social objectives. It was recognised that this may create individual cases of apparent injustice or hardship. ${ }^{81}$

$2 \quad$ The dissenting judges

Three of the seven judges disagreed with the majority's ruling. In a joint dissent, Bornello and Garlicki JJ noted that the majority judges seemed to agree that this was a case of apparent hardship and criticised the judgment for not providing a full explanation for why this injustice was nonetheless justifiable. ${ }^{82}$ Bornello and Garlicki JJ also highlighted the proposed amendment to the Civil Partnership Bill and stated that the concern that this was not the right vehicle to recognise relationships such as that between the Burden sisters, did not "absolve the legislature from providing an equitable solution to the problem at a later stage." ${ }^{83}$ The Judges further considered that: ${ }^{84}$

\footnotetext{
The situation of permanently cohabiting siblings is in many respects emotional as well as economical - not entirely different from the situation of other unions, particularly as regards old or very old people. The bonds of mutual affection form the ethical basis for such unions and the bonds of mutual dependency form the social basis for them. It is very important to protect such unions, like any other union of two persons, from financial disaster resulting from the death of one of the partners. The national legislature may establish a very high threshold for such unions to be recognised under tax exemption laws; it may also provide for particular requirements to avoid fraud and abuse. But unless some compelling reasons can be shown, the legislature cannot simply ignore that such unions also exist.
}

The judges went on to state that the injustice inherent in the Government's approach was acute in this situation due to the fact that the sisters were elderly, had been together for several decades and did not have children. As such the state would collect tax when each sister died, instead of once when the second sister died, and this occurred in a situation where the surviving sister would need to sell the family home to pay the tax bill.

\footnotetext{
${ }^{81}$ Ibid at 654 .

${ }^{82}$ Ibid, at 656 .

${ }^{83}$ Ibid.

${ }^{84}$ Ibid.
} 
The third dissenting judge also considered that the majority ruling was unfair, stating that: ${ }^{85}$

It strikes me as absolutely awful that, once one of the two sisters dies, the surviving sister's sufferings on account of her closest relative's death should be multiplied by the risk of losing her family home because she cannot afford to pay inheritance tax in respect of the deceased sister's share of it.

\section{E Decision of the Grand Chamber on Appeal}

The sisters then appealed the case to the Grand Chamber of the European Court of Human Rights, the majority ruling in favour of the United Kingdom.

\section{The majority judges}

The Grand Chamber, in ruling against the Burden sisters, also relied upon the fact that the sisters had not registered their relationship, stating that "the legal consequences of civil partnership ... which couples expressly and deliberately decide to incur, set these types of relationship apart from other forms of co-habitation." ${ }^{, 86}$ What is particularly surprising about this ruling, is that the Grand Chamber did not consider that the "length or the supportive nature of the relationship" mattered, but rather, "what is determinative is the existence of a public undertaking, carrying with it a body of rights and obligations of a contractual nature. $\$ 87$

It should be observed that this argument could not be made in relation to New Zealand law for two reasons. The first is that New Zealand law recognises de facto relationships, and as such, a public undertaking is not required for a relationship to be recognised. Second, New Zealand has abolished estate duty (the equivalent of inheritance tax), which suggests that inheritance tax does not necessarily need to be linked to other rights and obligations. The Grand Chamber also considered that the relationship between the Burden sisters was "qualitatively" different from that of a conjugal couple as: ${ }^{88}$

\footnotetext{
${ }^{85}$ Ibid, at 658-659.

${ }^{86}$ Burden v United Kingdom (Grand Chamber), above n 75, at 876.

${ }^{87}$ Ibid.

${ }^{88}$ Ibid.
} 
The very essence of the connection between siblings is consanguinity, whereas one of the defining characteristics of a marriage or Civil Partnership Act union is that it is forbidden to close family members ... the fact that the applicants have chosen to live together all their adult lives, as do many married and Civil Partnership Act couples, does not alter this essential difference between the two types of relationship. Moreover ... marriage confers a special status on those who enter into it ... and gives rise to social personal and legal consequences.

The Grand Chamber did not further expand on the essence of this "qualitatively" different nature. Bjorgvinsson J, who supported the majority, observed that this reasoning was circular and considered that the majority should have focused on substantive or material difference in the nature of the relationship. In fact, he considered that the Burden sisters' relationship could arguably be analogous to a marriage or marriage-like relationship, stating that: ${ }^{89}$

Despite important differences, mainly as concerns the sexual nature of the relationship between married couples and civil partner couples, when it comes to the decision to live together, closeness of the personal attachment and for most practical purposes of daily life and financial matters, the relationship between the applicants ... has ... for the alleged purposes of the relevant inheritance tax exemptions in particular, more in common with the relationship between married or civil partnership couples, than the differences between them.

However, in concurring with the majority, Bjorgvinsson $\mathrm{J}$ considered that the institution of marriage was closely linked with the idea of the family as one of the cornerstones of the social structure in the United Kingdom and other member states. Imposing a duty on member states to extend the applicability of social security and tax benefits might have significant consequences and should therefore come within the margin of appreciation afforded to states.

Two states also made third party submissions in support of the United Kingdom. ${ }^{90}$ In particular, the Government of the Republic of Ireland submitted that the Burden sisters were not in a position analogous to a married couple or civil partnership, as people in these relationships have chosen to assume legal obligations. Rather, their position was analogous to any persons in an

\footnotetext{
${ }^{89}$ Ibid, at $877-878$.

${ }^{90}$ Ibid, at $874-5$.
} 
established, mutually supportive, cohabiting relationship. The Government of Belgium submitted that the British Government should be able to pursue the policies it considered provided the best prospect for family stability.

\section{$2 \quad$ The dissenting judges}

The two dissenting judges disagreed with the approach taken by the majority, considering that there was no qualitative difference between that of the sisters and conjugal couples. Zupancic J stated that: ${ }^{91}$

The quality of consanguinity is different from sexual relationships, but this has no bearing on the proximity of the persons in question. So what does the qualitative difference referred to by the majority come to? Is it having sex with one another that provides the rational relationship to a legitimate government interest?

Zupancic $\mathrm{J}$ considered that, if the state extended such a benefit to one non-marital group, then it should be extended, where reasonable, to others. $\mathrm{He}$ considered consanguinity to be an arbitrary impediment. Borrego $\mathrm{J}$, also dissenting, considered that if the state decided to create a benefits scheme it was bound to do so in a manner that was compatible with the right to be free from discrimination. $^{92}$

\section{F Burden v United Kingdom: Concluding Thoughts}

The Burden sisters' case is significant because it shows that it is not contrived to suggest that two people in a non-conjugal relationship may consider that their relationship should attract a similar status to conjugal relationships, at least for a particular purpose. The arguments of the British Government and the majority judges in each instance do not convincingly set out how the Burden sisters' relationship differs qualitatively from a conjugal relationship. Justice Borrego derided this failing, stating that "The fact that the Grand Chamber did not give a reply to the applicants, two elderly ladies, fills

\footnotetext{
${ }^{91}$ Ibid, at 881.

${ }^{92}$ Ibid, at 884 .
} 
me with shame, because they deserved a different approach. ${ }^{93}$ Similarly, Welstead observes that: ${ }^{94}$

In functional terms, it is difficult to see how the relationship between Joyce and Sybil Burden could properly be regarded in any way other than analogous with that of a married couple or a same-sex partner. They had chosen to live with each other in their family home in a loving, committed and stable relationship for many decades, foregoing the possibility of marriage or civil partnership with any other person, yet unable to legalise that relationship because of their consanguinity.

Article 8 of the European Convention for the Protection of Human Rights and Fundamental Freedoms was not relied upon by the applicants or dissenting judges. Article 8 refers to the right to respect for family life and home. The concern behind the Burden sisters' complaint was that the surviving sister might be required to sell the family home due to the imposition of an inheritance tax. However, it is likely that an argument was not made under this Article as the ground of family life has traditionally been interpreted narrowly under the Convention.

\section{De Facto Relationships: The Legal Test for Conjugality}

This section considers the legal test for identifying relationships in the nature of marriage and how it defines conjugality. It also discusses the extent to which this test can be used to differentiate conjugal and non-conjugal relationships. In New Zealand, relationships in the nature of marriage are known as de facto relationships. ${ }^{95}$ De facto relationships are a legal phenomenon. While they are intended to reflect social practices, they represent an attempt to define the attributes associated with marriage and, in other words, conjugality. This means that people who do not choose to register their relationship as a legal marriage are, nonetheless, subject to similar laws as married couples. It is de facto relationships that provide us with a meaningful understanding of how the law defines conjugality.

\footnotetext{
${ }^{93}$ Ibid, at 884 .

94 Mary Welstead "England and Wales: The Family the Law Forgot" in Bill Atkin (ed) The International Survey of Family Law 2010 Edition (Jordans, Bristol, 2010) 113 at 118.

${ }^{95}$ Interpretation Act 1999, s 29A.
} 


\section{A What is Marriage-Like Like?}

Defining what is marriage-like is a highly prescriptive and ideological exercise, at odds with a society that is increasingly accepting of diverse relationships. However, as suggested in the following chapter, there are good reasons for recognising relationships which people have chosen not to register. Where this is the case, the law must identify criteria for recognising these relationships. New Zealand takes the same approach to defining a de facto relationship as other commonwealth countries, which involves listing a set of factors (similar across countries) that can be used to help establish that two people are living together as a couple.

Rights and responsibilities were comprehensively accorded to de facto partners in the twenty-first century in New Zealand under the Relationships (Statutory References) Act 2005. This Act amended many different statutes so that de facto partners were recognised for almost all of the same legal purposes as married couples. In New Zealand, the default definition of a de facto relationship is set out in s 29A(1) of the Interpretation Act 1999, which defines "de facto relationship" as a relationship between two people who "live together as a couple in a relationship in the nature of marriage or civil union." Section $29 \mathrm{~A}(3)$ of the Interpretation Act further provides that in determining whether such a relationship exists, regard must be had to the context, or the purpose of the law, in which the question is to be determined, as well as all the circumstances of the relationship.

De facto relationship is a nebulous concept, incapable of precise definition and capable of changing meaning according to context, save for the requirement to be "living together as a couple". 96 This is not necessarily problematic and Atkin suggests that most situations will fall easily within or outside of the definition of de facto relationship. ${ }^{97}$ In New Zealand, s $2 \mathrm{D}$ of the Property (Relationships) Act 1976 provides a comprehensive definition of de facto relationship upon which many other statutes and the common law have been modelled. The Act provides that in determining whether two persons live

\footnotetext{
${ }^{96}$ Ruka v Department of Social Welfare [1997] 1 NZLR 154.

${ }^{97}$ Bill Atkin "The legal world of unmarried couples: reflections on "de facto relationships" in recent New Zealand legislation” (2009) 39 VUWLR 793 at 811.
} 
together as a couple, all the circumstances of the relationship are to be taken into account, including any of the following matters that are relevant in a particular case: ${ }^{98}$

- the duration of the relationship;

- the nature and extent of common residence;

- $\quad$ whether or not a sexual relationship exists;

- the degree of financial dependence or interdependence and any arrangements for financial support, between the parties;

- $\quad$ the ownership, use, and acquisition of property;

- $\quad$ the degree of mutual commitment to a shared life;

- $\quad$ the care and support of children;

- the performance of household duties; and

- the reputation and public aspects of the relationship.

The Act also directs that no finding in respect of any of these matters is necessary, and a Court is entitled to have regard to these matters, and to attach such weight to any matter, as the Court considers appropriate in the circumstances of the case. As far back as in Thompson $v$ DSW Tipping $\mathbf{J}$ emphasised the ultimate decision will always be one of fact and degree, stating that: ${ }^{99}$

A relationship between a couple may adopt a variety of forms which fall short of a de facto relationship. They may be friends or lovers, boyfriend and girlfriend, landlady and boarder, or flatmates in circumstances which fall short of a de facto relationship.

A full discussion of each of these factors is unnecessary for the purposes of this thesis. Cossman and Ryder observe that non-conjugal relationships may be characterised by joint residence, emotional intimacy, economic interdependency, domestic care and support, and economic dependence or

\footnotetext{
${ }^{98}$ Tipping J observes that "The list is derived substantially from the earlier case law of which the case of Ruka v DSW [1997] 1 NZLR 154 and my own earlier decision in Thompson $v$ DSW [1994] 2 NZLR 369 were probably the best known examples.” See Andrew Tipping, Judge of the Supreme Court of New Zealand "Sea of Changes in New Zealand Couples' Property Rights" (Freshfields Bruckhaus Deringer, 16 May 2002).

${ }^{99}$ Thompson v DSW [1994] 2 NZLR 369 at 374.
} 
interdependency. ${ }^{100}$ In short, such relationships "may be characterized by many of the dimensions of family life that give rise to legal rights and responsibilities on the functional equivalence approach."101 It is apparent that factors such as a shared dwelling and a relationship of long duration can apply to non-conjugal relationships such as that between the Burden sisters, who might even share their finances to a greater degree than some conjugal relationships.

This section focuses on three aspects of the test, namely, sexual intimacy, a mutual commitment to a shared life and the concept of living together as a couple (the latter, being the overarching test). It is these factors which may be more readily relied upon to distinguish conjugal and nonconjugal relationships. Sexual intimacy and the concept of living together as a couple do not apply to non-conjugal relationships, but are they material distinctions on which decisions can be appropriately be made regarding legal status? In the case of a mutual commitment to a shared life, the question is whether this factor can be present to a degree in conjugal relationships that it is not in non-conjugal relationships.

The factors of financial dependency and interdependency are not discussed, as it is difficult to distinguish between conjugal and non-conjugal relationships on this basis. While financial interdependency may be present to a greater degree in conjugal relationships, some conjugal couples keep separate finances whereas some non-conjugal partners may not.

\section{$1 \quad$ Sexual intimacy}

It is difficult to contemplate a non-conjugal relationship involving sexual intimacy, given the historical association of conjugality and sexual relationships. This means that certain personal relationships which are not typically recognised by the law, such as boyfriend and girlfriend relationships, should perhaps be seen as a category of conjugal relationship which does not meet the threshold for legal recognition. In the same way, the argument does not need to be that all non-conjugal relationships require recognition, but rather those that meet certain criteria should be recognised by the law.

\footnotetext{
${ }^{100}$ Cossman and Ryder "The Irrelevance of Conjugality", above n 1, at 271.

101 Ibid.
} 
The declining relevance of sexual intimacy as a factor for determining whether a conjugal relationship exists has eroded, at least conceptually, a key difference between conjugal and non-conjugal relationships. Cossman and Ryder write that in Canada: ${ }^{102}$

\begin{abstract}
Sex, once the hallmark of a conjugal relationship, has become legally less important, to the point that the Supreme Court has suggested that a relationship may be conjugal even if the individuals do not have a sexual relationship.
\end{abstract}

In this respect, Harder observes that many sexual relationships do not carry expectations of commitment and support from the participants, just as many relationships that do carry such expectations are not sexual. ${ }^{103}$ Both Harder and Cossman and Ryder support the de-emphasis on sexual intimacy, as they consider that whether a relationship has a sexual component or not bears no relation to the achievement of legitimate state objectives. Cossman and Ryder consider such an inquiry offensive because it requires participants to publicly disclose private details of their intimate lives. The problem is, as expressed by Cossman and Ryder, that a sexual relationship "is often assumed in ordinary parlance to be a central if not defining feature of a "conjugal" relationship."104

In New Zealand, although there is a favouring of relationships with some degree of sexual content, this factor is neither determinative nor essential to establish. In Scott v Scragg the High Court expressed the opinion that the relationship between a couple who had never lived together or had a sexual relationship due to religious beliefs, would qualify as a de facto relationship under s 2D of the Property (Relationships) Act $1976 .{ }^{105}$ In $R D P v F M N$ the court considered that a de facto relationship had not been established, despite the presence of a sexual relationship, because the relationship lacked "the quality of commitment and intimacy which would normally feature in a sexual relationship between a couple committed to each other."106 The reasons why

\footnotetext{
${ }^{102}$ Cossman and Ryder "The Irrelevance of Conjugality", above n 1, at 269.

103 Lois Harder "The State and the Friendships of the Nation: The Case of Nonconjugal Relationships in the United States and Canada" (2009) 34 Signs Journal of Women in Culture and Society 634 at 650 .

104 Ibid, at 298.

${ }^{105}$ Scott v Scragg [2005] NZFLR 577. The case in question was Horsfield v Giltrap [2001] BCL 656.

${ }^{106} R D P$ v FMN [2006] NZFLR 573
} 
there is no sexual relationship are nonetheless relevant and Jefferson writes that: $^{107}$

An ongoing sexual relationship between parties is likely to have lesser significance than the existence of a sexual relationship at some time during the relationship. For example an older couple who live together for companionship and convenience and become mutually dependent upon one another both financially and emotionally.

Sexual intimacy still continues to be part of the inquiry as to whether a conjugal relationship exists. This is consistent with the conceptualisation of conjugality proposed by Bennett, whereby sexual relationships may be relevant as an expression of an "activity of exclusive concern". Bottomley and Wong suggest that: ${ }^{108}$

\begin{abstract}
What all these emerging patterns make clear is that extensions to cover others tend to include the drawing of lines around a central nexus of either marriage or sexual partnerships, although the unwillingness to speak of sexual practice tends to lead to a fudge which allows for slippage into non-sexual partners. This slippage has to be distinguished from the more definite moves made in some jurisdictions to extend protection to the economically vulnerable, especially carers, even if they meet at a point where a shift in focus to economic vulnerability allows detraction from the issue of equality for sexual partners.
\end{abstract}

This suggests that a decline in the relevance of sexual intimacy is eroding the legal distinction between conjugal and non-conjugal relationships. Cossman and Ryder also observe that case law is "undermining the very distinction between conjugal and non-conjugal relationships on which legislative definitions of spouse and common law partner rest."

\title{
$2 \quad$ Commitment to a shared life and living together as a couple
}

While a commitment to a shared life and living together as a couple are different concepts, they are closely related and are considered here together. Earlier in the chapter, an argument was advanced by Bennett that the

${ }^{107}$ Simon Jefferson "De facto or 'friends with benefits'?" (2007) 12 NZ Family Law Journal 304 at 307.

${ }^{108}$ Anne Bottomley and Simone Wong "Shared Households: A new Paradigm for Thinking about the Reform of Domestic Property Relations" in Alison Diduck and Katherine O'Donovan (eds) Feminist Perspectives on Family Law (Routledge Cavendish, New York, 2006) 39 at 48.

${ }^{109}$ Cossman and Ryder "The Irrelevance of Conjugality", above n 1, at 284. 
commitment present in conjugal relationships is qualitatively different from that in non-conjugal relationships. In law, commitment is a factor that can be manifested in many ways, including sexual fidelity, emotional commitment, financial commitment and through the length of time spent in a relationship. The court in RDP $v F M N$ observed that a degree of mutual commitment to a shared life is a factor: ${ }^{110}$

... which threads through all of the other circumstances detailed in $\mathrm{s} 2 \mathrm{D}(2)$. It refers to the quality of all the other factors which might indicate the existence of a qualifying de facto relationship. In a sense, it touches the ethos of the Act, whereby individuals who mutually commit to a shared life together acquire rights in the property of each other because of a partnership binding them together.

In terms of what commitment requires, Jefferson writes: ${ }^{111}$

What needs to be present is a measure of mutual commitment by the parties to the relationship. It need not be a commitment intended to last forever or indefinitely. Nor need it even be a commitment to a long term relationship. There must, however, be at the very least a commitment for the foreseeable future ... Even that will not be determinative - presumably one can be committed to a friendship or a love affair without converting it into a de facto relationship. The very concept of "commitment" is not easy to grapple with.

Arguably, commitment to a shared life is less likely to be present in nonconjugal relationships due, as Bennett suggests, to the exclusive nature of conjugal relationships. However, it is difficult to argue that this type of commitment is not present in the relationship between the Burden sisters. Perhaps society needs to be prepared to recognise that some non-conjugal partners, particular elderly siblings living together, may indeed intend their relationship to last in this manner. Bala also queries why individuals should be denied a benefit because they do not have a particular kind of emotional commitment or do not have a sexual relationship. ${ }^{112}$

\footnotetext{
${ }^{110} R D P$ v FMN [2006] NZFLR 573

111 Jefferson "friends with benefits", above n 107, at 307.

112 Nicholas Bala "Alternatives for Extending Spousal Status in Canada" (2000) 17 Can J Fam L 169 at 194
} 
With respect to the concept of living together as a couple, Atkin observes that when assessing whether a de facto relationship exists, "the list is not one to be assessed by counting up ticks and crosses", it is not "exhaustive" and, most importantly, "must not overshadow the central concept itself of living together." 113 However, it is likely that where a commitment to a shared life exists, at least in the case of a conjugal couple, this will lead to a finding that participants are living together as a couple. For what else can conjugality mean, sexual intimacy aside? Nonetheless, it is unlikely a court would accept that any two people in a non-conjugal relationship were living together as a couple, even if there was no material distinction in the functions the relationship served. For this reason, the relationship recognition regimes for non-conjugal relationships outlined in Chapter Four, while adopting most or all of the other aspects of the legal test for de facto relationships, omit this requirement.

\section{Conclusion - destablisation of the conceptual divide between conjugality and non-conjugality}

It is clear that there has been a conceptual destabilisation of the historically clear legal divide between conjugal and non-conjugal relationships. However, it is unlikely that courts in the near future will face difficult cases where a plaintiff seeks the application of the test for a de facto relationship to a non-conjugal relationship. This is because it is possible, despite the preceding analysis, to tell a conjugal and non-conjugal relationship apart. There was no mistaking the Burden sisters for a couple due to the fact that they were sisters. Even if they had been close friends, if they did not present their relationship as a romantic relationship, it would still be possible to distinguish their relationship simply because they did not seek to be treated as a couple in the ordinary sense of the word. A more difficult situation might arise, nonetheless, if, of two unrelated persons, one claimed that a de facto relationship existed while the other claimed that the relationship was platonic.

The real question is whether there is a material distinction between conjugal and non-conjugal relationships. In all respects other than sexual intimacy and any "romantic" considerations, it is questionable whether the

\footnotetext{
${ }^{113}$ Bill Atkin "The legal world of unmarried couples", above n 56, at 800.
} 
criteria for identifying a de facto relationship are materially different from the factors that could apply to a particular non-conjugal relationship. In the case of the Burden sisters, it is arguably difficult to single out any individual factor that is likely to not have been present in their relationship, aside from sexual intimacy. Rather the distinction is made on the basis that they are sisters and therefore could not be a couple. As set out above, the majority judges in the Grand Chamber considered the difference was that they were sisters and had not registered their relationship, which is not actually a material difference.

The simple fact that it is clear that the Burdens are not a couple in the romantic sense does not provide a concrete basis for making a distinction with serious legal consequences. Nevertheless there may be some qualitative differences between conjugal and non-conjugal relationships, which are simply hard to identify when considering a close and enduring non-conjugal relationship such as that between the Burden sisters. If so, this arises due to the degree to which conjugal relationships are likely to exhibit factors such as commitment to a shared life. Many non-conjugal relationships would not be founded on this premise, due to the fact that those in non-conjugal relationships may hope to enter into a conjugal relationship in the future or may already be in such a relationship. This may lead to a material distinction in the living arrangements between the two types of relationship.

Overall, however, it is clear that non-conjugal relationships can exhibit the characteristics of conjugal relationships. There is also a question as to why non-conjugal relationships should need to live up to an idealised conjugal relationship to receive recognition, or indeed why they cannot receive recognition in their own right, without a conjugal reference point. Recognition does not necessarily need to be for all the same purposes as marriage or marriage-like relationships. What is important is that the state begin to acknowledge more clearly that a wider range of relationships may be relevant than conjugal relationships when developing laws that affect personal relationships (as has already been recognised in the case of domestic violence with the establishment of a category of "domestic relationship"). The remainder of this chapter continues to develop the case for recognising the importance of 
non-conjugal relationships through discussing the state's interest in supporting a wide range of personal relationships and the trend towards diverse and expansive understandings of the relationships "family" includes.

\section{The State's Interest in Recognising a Wider Range of Personal Relationships}

The state has a particular interest in recognising conjugal relationships due to their procreative and child-rearing functions. However, not all conjugal relationships result in children, yet the state still has an interest in supporting these relationships so that they can flourish as follows. First, the state must maintain social order. Individual well-being affects social order and personal relationships have a significant impact on well-being. Second, the state is concerned with the allocation of scarce resources and personal relationships allow for the privitisation of dependency and thereby lessen the burden on the state's finances. These two particular interests of the state are fostered by recognising a broader range of relationships than those that are conjugal as set out below.

With respect to social order, Rawls writes that "survival depends in significant part on the altruistic behavior of others. A society or group cannot manage all the tasks of physical, economic and emotional living without cooperation from each other." "114 The consequence of living in societies is that social order between citizens must be maintained by the state. Social cohesion is the term used to describe the bonds that bring people together in society. ${ }^{115}$ Key elements of social cohesion are positive interactions and active social relationships. ${ }^{116}$ Personal relationships are ultimately an important source of social connectedness which is integral to well-being. Relationships are a source of support and happiness, and give people a sense of their place in society.

\footnotetext{
${ }^{114}$ John Rawls A Theory of Justice (Oxford University Press, New York, 1971) at 794.

115 Ibid.

${ }^{116}$ Office of the Deputy Prime Minister State of the English Cities (2006).
} 
From the state's perspective it is important that citizens have a network of happy and healthy personal relationships to draw on. In particular: ${ }^{117}$

Several studies have demonstrated links between social connectedness and positive outcomes for individual health and wellbeing. Social connectedness is fostered when family relationships are positive, and when people have the skills and opportunities to make friends and to interact constructively with others.

The state is also interested in encouraging relationships in which economic support is provided. ${ }^{118}$ An obvious example of economic support is for someone who is unemployed. However, there is also an economic impact for the state in circumstances such as when people are in hospital because there is no one to care for them at home, or elderly people who require assistance to live independently. People who are expected to provide social support to other individuals may receive certain benefits, such as tax relief, in the expectation that this will encourage and allow them to adequately discharge their responsibilities. This arrangement is often the basis for the recognition of social groupings.

\section{Non-Conjugal Relationships as Family Relationships}

The final task of this chapter is to consider the concept of a non-conjugal relationship. It is difficult to articulate a definition of non-conjugality. At its simplest, a non-conjugal relationship is one that is not conjugal. However, this is a broad definition that does not distinguish particular relationships that may warrant legal recognition in some way. The differences between different nonconjugal relationships are important because they affect our notions about the justice of extending certain legal rights and obligations to different types of nonconjugal relationships. Put simply, some non-conjugal relationships may need state support and other recognition whereas others may not, but how can we differentiate between these relationships?

Essentially, a non-conjugal relationship, like a conjugal relationship, may be defined by reference to a particular status (in particular, a family status)

\footnotetext{
${ }^{117}$ Ministry of Social Development The Social Report (2009).

118 See Martha Fineman "Masking Dependency: The Political Role of Family Rhetoric" (1995) 81 Va L Rev 2181.
} 
or a list of functional criteria. With respect to the latter, these may vary depending on the particular law in question. However, a non-conjugal relationship that is relevant to the law is essentially a personal relationship of a sufficiently close degree, typically involving some or many of the types of factors that are usually identified with de facto relationships, such as interdependency, commitment, caring and support. The nature of these factors suggests that some non-conjugal relationships are effectively family relationships.

It is commonly recognised that the family is a fundamental and natural grouping within society and serves many important functions. ${ }^{119}$ The natural law tradition conceives of the family as an institution ordained for reproduction and comprising a father, mother and child. However, modern theorists argue that family is a social construct and that family definitions and practices have varied enormously over time, place and culture. In recent times there has been a re-envisaging of the family. Ettelbrick suggests that "In the past fifty years alone, family structure and meaning have changed remarkably as a result of several distinct and intertwined social justice movements."

Family law is now interested in a range of intimate personal relationships, whether or not they are understood as family relationships in a traditional sense. The Families Commission states that: ${ }^{121}$

Legal and policy definitions of family relationships are continually evolving in New Zealand in order to take account of changing social and cultural norms ... New Zealand law seeks to be 'relatively neutral' with respect to the kinds of social relationships that constitute a family.

The Families Commission also suggests that "increasingly we conceive of families in terms of what they do - sharing resources, caring, responsibilities and obligations - rather than the particular organisational form they take."122

\footnotetext{
${ }^{119}$ See The Universal Declaration of Human Rights, Art 16(3).

${ }^{120}$ Paula L Ettelbrick "Domestic Partnership, Civil Unions, or Marriage: One Size Does Not Fit All” (2001) 64 Alb L Rev 905 at 906.

121 The Families Commission Family Centred Communities (2010).

122 Ibid.
} 
Families provide love, care, and socialisation to others in the family group, and the family group: ${ }^{123}$

... has common goals and shares concern for each other, the individuals that comprise the group usually are "liked-minded" adults, sometimes with children, and the individuals respond to biological, emotional, spiritual, and economic needs of the group and, to the extent possible, self care. Most frequently the members of the group focus on extending love and care to the other members.

Ultimately, it could be appropriate to view many of the non-conjugal relationships which are important to the law as family relationships. It has been observed that relationships between non-relatives "can be experienced as the equivalent of biological or legal ties." 124 This is reflected in the Human Rights Act 1993, in which the term "relative is not limited to relatives by blood. The law is increasingly willing to consider "family-like" relationships for particular legal purposes. This does not mean, however, that legal recognition of nonconjugal relationships should be limited to relationships that might be considered family relationships. Even a simple friendship can be relevant to the law, as will be seen in the fifth chapter. The point is more that those nonconjugal relationships that are or resemble family relationships are likely to be the relationships of most relevance to the law and most in need of recognition and support, due to the degree of intimacy they exhibit.

\section{Conclusion}

Conjugality was simple in its inception, referring to marriage or sex within marriage. Legal marriage itself was and continues to be characterised by procedural, rather than substantive requirements. However, society has evolved to recognise a more diverse range of relationships. The advent of marriage-like relationships has meant that the law has had to define conjugality and has done so by identifying the idealised attributes of a marriage.

These attributes include factors such as commitment, caring and interdependency. However, the range of personal relationships which perform

\footnotetext{
123 Jane E Cross, Nan Palmer, and Charlene L Smith "Families Redefined: Kinship Groups that Deserve Benefits" (2009) 78 Mississippi Law Journal 791 at 792.

${ }^{124}$ Law Commission of Canada Beyond Conjugality, above n 47, at 5.
} 
these functions is not limited to marriage-like relationships, and can include close non-conjugal relationships. In fact, the legal divide between marriage-like relationships and non-conjugal relationships, such as that between the Burden sisters, has been destabilised, as courts and commentators have questioned the relevance of sexual intimacy as a criterion for recognising relationships.

Arguably, however, the law can still materially distinguish between conjugal and non-conjugal relationships. Conjugality can be understood, ideally, as a personal relationship in which each partner exclusively values and commits to the other. This suggests that there may be qualitative differences between the type of commitment and interdependency in conjugal and nonconjugal relationships, with conjugal relationships typically exhibiting a greater degree of intimacy and sharing of lives. Sexual intimacy is one manifestation of such commitment. It is this feature of conjugal relationships, in addition to conjugality's procreative function, which the state seeks to promote in terms of the positive benefits that arise for conjugal partners.

Ultimately, the living arrangements in non-conjugal relationships and the expectations of parties are generally likely to be different from those in conjugal relationships. However, there are exceptional cases, and it is difficult to identify a basis for distinguishing between the life-long relationship between the elderly Burden sisters and an elderly married couple, that should matter for apportioning legal rights and responsibilities.

In addition, even if two people are not living together as a couple, this does not mean their relationship is irrelevant to the law. Rather, the question is how their relationship should be recognised by the law. The state has an interest in supporting and promoting close non-conjugal relationships as these relationships provide important benefits. Close non-conjugal relationships can even be experienced as family relationships. 


\section{CHAPTER THREE: MODELS FOR RECOGNISING PERSONAL RELATIONSHIPS}

\section{Introduction}

Imagine a scenario where the United Kingdom conceded that the Burden sisters had been treated unfairly compared to civil partners under the Civil Partnership Act 2004, resolving to change the law so that the sisters would not have to pay inheritance tax. How could this be effected?

Certainly, the British Government could exempt relatives who have lived together for a certain period of time from paying inheritance tax. ${ }^{1}$ But should siblings receive such a privilege without being subject to other obligations? Should they be required to register their relationship to receive this benefit? What about other close personal relationships? In fact, inheritance tax could even be abolished completely, without having regard to relationships, as has been its equivalent in New Zealand. ${ }^{2}$

The question of whether a non-conjugal relationship should be recognised cannot be separated from the question of how the relationship is recognised. In New Zealand, a small number of legal models are used to recognise a range of personal relationships. Choice of legal model is important because it determines how a relationship is recognised, which has significant consequences. For example, do people voluntarily assume obligations or are they imposed on them? Are third parties affected or are the legal consequences limited to parties in the relationship? The model of recognition chosen can also affect the nature of the rights and responsibilities associated with a relationship.

\footnotetext{
${ }^{1}$ As previously noted, during debate in the House of Lords on the Civil Partnership Bill, an amendment was introduced which would have allowed the legislation to apply to same or opposite-sex family members within the prohibited degrees of relationship if they were over thirty years of age, they had cohabited for at least twelve years and they were not already married or in a civil partnership with some other person. The House of Commons later removed the amendment. See generally (22 April 2004) 662 GBPD HL 1362.

2 Estate duty in New Zealand was the equivalent of the United Kingdom's inheritance tax. Estate duty was abolished by the Estate Duty Abolition Act 1993. Prior to this, gift duty was introduced to prevent individuals from circumventing estate duty tax laws. Gift duty was retained when estate duty was abolished. However, the Government is currently considering a proposal to abolish gift duties as well. See Hon Peter Dunne "Government Signals Repeal of Gift Duty" (press release, 14 June 2010).
} 
This chapter briefly identifies the characteristics of each model, analyses the advantages and disadvantages, and observes how these models have been applied to conjugal and non-conjugal relationships in New Zealand. The aim is to build an understanding of the basic options that are available for recognising personal relationships. In the following chapter, this thesis considers how other countries have taken approaches to recognising non-conjugal relationships that New Zealand has not yet considered.

\section{Models for Recognising Relationships}

There are three basic legal models for recognising personal relationships and common law jurisdictions typically employ a combination. New Zealand uses each of these models to recognise conjugal relationships. These models are also applied to non-conjugal relationships, but to a more limited extent. They are: registration, ascription and private law (or contract). These models represent an accepted classification of the ways in which the law can recognise personal relationships. ${ }^{3}$ However, marriage is sometimes considered as a separate model, rather than part of the registration model. ${ }^{4}$ This tends to reflect the political nature of marriage rather than key legal differences between marriage and other registration models.

Nevertheless, marriage has not always been solely a registered relationship. For example, in New Zealand, Māori customary marriage practices used to be common and, although unregistered, were recognised by the State until 1952, when all marriages had to be registered. ${ }^{5}$ This can be contrasted with South Africa, where the Customary Marriages Act 1998 provides for the civil registration of marriages solemnised according to the traditions of indigenous tribes (including polygamous marriages).

\footnotetext{
${ }^{3}$ See generally Law Commission of Canada Beyond Conjugality: Recognizing and supporting close personal adult relationships (2001).

${ }^{4}$ This was the approach taken by the Law Commission of Canada in Beyond Conjugality, ibid.

${ }^{5}$ Law Commission Justice: The Experiences of Māori Women (NZLC R 53, 1999) at 23.
} 


\section{A Registration}

\section{$1 \quad$ General features}

In New Zealand, marriages and civil unions are examples of the registration model. The Marriage Act 1955 regulates marriages and the Civil Union Act 2004, civil unions. Marriage is the most prevalent registration scheme in common law countries. However, registration schemes do not need to be based on marriage, although they do tend to develop in parallel to it. ${ }^{6}$ The key characteristic of the registration model is the act of voluntary registration. People must choose to opt in. Often a repository will be established to record registrations. The registration approach respects the free will of parties, who must consent to become subject to the law. This gives them the opportunity to identify the consequences of registration and assess them in advance (although parties may not always do so). The South African Law Reform Commission suggests that "the benefit of this approach is ... the certainty and peace of mind it provides from the moment of registration." 7

Other formal attributes associated with the registration model are entry criteria, legal implications and international implications. ${ }^{8}$ In particular, people must usually meet certain criteria to register their relationship. For example, in New Zealand, marriage must be between a man and a woman. ${ }^{9}$ There must also be consent and parties must not be within the prohibited degrees of consanguinity or affinity. ${ }^{10}$ As suggested in Chapter Two, a relationship does not need to serve a particular function to be registered as a marriage and there is

\footnotetext{
${ }^{6}$ Law Commission of Canada Beyond Conjugality, above n 3, at 117.

${ }^{7}$ South African Law Reform Commission Domestic Partnerships (DP 104, 2003) at 10.1.1.

${ }^{8}$ Barbara Stark International Family Law: An Introduction (Ashgate Publishing Limited, Hants (England), 2005) at 42. Marriages are generally recognised between countries. However, it is less common for same-sex unions to be afforded international recognition. New Zealand only recognises same-sex registered partnerships in five overseas countries. These countries are prescribed by the Civil Union (Recognised Overseas Relationships) Regulations 2005 and the relationships recognised are: a registered partnership (Finland); a life partnership (Germany); a civil partnership (the United Kingdom); a domestic partnership (New Jersey, USA); and a civil union (Vermont, USA). One reason for limiting recognition of overseas registered partnerships is because the entry criteria may not be equivalent to those for civil unions in New Zealand (for example, underage partnerships can occur without parental consent).

${ }^{9}$ Quilter v Attorney-General [1998] 1 NZLR 523.

${ }^{10}$ See s 31 of the Family Proceedings Act 1980 and s 15 of the Marriage Act 1955 respectively. Section 31(1)(a)(ii) provides that a marriage or civil union shall be void "by reason of duress, mistake, or insanity, or for any other reason, there was at the time of the marriage or civil union an absence of consent by either party to marriage or civil union to the other party."
} 
no inquiry into the quality of the relationship. The entry criteria for marriage and civil unions in New Zealand relate to form, not substance. This preserves privacy and freedom and provides certainty for couples that their relationship will be recognised by third parties, including the state. Exit criteria also apply to the registration model and in New Zealand, married couples and civil union partners must be separated for two years before they can dissolve their union. ${ }^{11}$

The acquisition of status is also an overarching feature of the registration model. The ability to acquire status is said to symbolise to society the legitimacy of the relationship and allow the couple to publicly express their commitment to each other. Overall, the Law Commission of Canada outlines the benefits of registration schemes as arising from: ${ }^{12}$

... the characteristics of voluntariness, stability, certainty and publicity. They provide an orderly framework in which people can express their commitment to each other, receive public recognition and support, and voluntarily assume a range of legal rights and obligations ... These schemes affirm the basic principles and values that ought to guide the regulation of personal adult relationships, including equality and respect for diversity on one hand, and autonomy and freedom of choice on the other.

The registration model does have some disadvantages, however. Some commentators consider that registration schemes lend themselves to social engineering due to the criteria for entry and the way that rights and responsibilities are allocated within the scheme. For example, the differential treatment of women by early divorce regimes or the association between marriage and caregiving roles for women. ${ }^{13}$ Another disadvantage of the registration model is that it may unfairly exclude certain types of relationships. For instance, following the introduction of the Social Security Act 1938, several welfare measures became dependent on a registered marriage, disadvantaging unmarried mothers. ${ }^{14}$

\footnotetext{
${ }^{11}$ Family Proceedings Act 1980, s 39.

${ }^{12}$ Law Commission of Canada Beyond Conjugality, above n 3, at 117.

${ }^{13}$ Laura A Rosenbury (2007) "Friends with benefits? (family law doctrine)" 106 Mich L Rev 189 at 193.

${ }^{14}$ This was remedied with the introduction of the Domestic Purposes Benefit for sole parents in 1972. See the Social Security Act 1964.
} 
In addition:

... the most likely victims of injustice, those who need the protection, namely the vulnerable, disorganised, pressurised, naïve, unsophisticated and illinformed, are those who will most likely not register their partnership. They are also the ones who may be persuaded by a strong-willed partner not to register the relationship. Those whom the law aims to protect may thus not benefit from such a system.

For this reason, use of the registration model is usually complemented by the use of other models, which target those who choose not to or cannot register their relationship.

\section{Registration and non-conjugal relationships}

In the absence of a consummation requirement, the Marriage Act 1955 and the Civil Union Act 2004 do not expressly prevent all people in a nonconjugal relationship from registering their relationship. However, both Acts prevent people within the prohibited degrees of affinity or consanguinity from registering their relationships. Nevertheless, for the mostpart, it is the registration model that has been used overseas to recognise non-conjugal relationships.

To date, there is no registration scheme for recognising non-conjugal relationships in New Zealand. However, an example of a scheme that comes close to this is the legislative framework for enduring powers of attorney. If someone has lost the capacity to make, understand or communicate decisions, then a spouse cannot legally make decisions on behalf of that incapacitated person, if that person has not given them the power to do so. ${ }^{15}$ The Protection of Personal and Property Rights Act 1988 provides a way for decisions to be made for an incapacitated person, either by an "attorney" who the person has appointed earlier, or by a court or someone appointed by a court.

This differs from a typical registration scheme in that there is no central repository for recording who has a power of attorney over another person (this is unnecessary to achieve the policy intent and would, therefore, be inefficient).

\footnotetext{
${ }^{15}$ For example, the Human Tissue Act 1993. This is subject to any express power provided in legislation.
} 
However, as will be seen in the next chapter, some countries, in setting up comprehensive regimes to recognise non-conjugal relationships, also take this approach (whereby parties do not need to notify the state of their relationship, though entering into a relationship has significant legal consequences for the state and third parties and parties are required to enter into a formal agreement before a notary public).

The Protection of Personal and Property Rights Act 1988 allows people to decide in advance who will make decisions for them if they become incapable of making decisions for themselves, and to formally record this intention in the presence of a lawyer. This approach has more in common with the registration model than ascription or private contract, as arrangements are governed by legislation, are voluntary and affect third parties. This also shows that it is possible to have a registration scheme that is very targeted.

In allowing non-conjugal partners to enter into a registration scheme, there are certain questions that must be considered. In particular, is it appropriate to extend all the rights and benefits of marriage to non-conjugal partners? How do non-conjugal partners feel about registering their relationship, particularly given the symbolic functions of recognition and that they may, at some point in the future, wish to enter into a conjugal relationship (if they are not in a conjugal relationship already)? What are the criteria for entry and what is the process for termination? As will be seen in the following chapter, while the criteria for entering into a marriage are procedural in nature, the criteria for registering a non-conjugal relationship tend to require the relationship to serve a certain function.

\section{B Ascription \\ $1 \quad$ General features}

Ascription refers to the imposition of legal status on parties. Ascription schemes can confer recognition for the same purposes as registration schemes, but parties do not expressly consent to be bound by rights and obligations. De facto relationships in New Zealand are based on the ascription model. A key benefit of ascription is that it addresses the risks of exploitation in personal 
relationships where there is a power imbalance. It does this by ascribing a set of rights and obligations that are presumed to correspond with the expectations of most people in such relationships. ${ }^{16}$ Ascription also allows the state to extend support structures to dependents of people in these relationships. Ascription is one way of providing legal recognition to controversial relationships, as it may be more politically viable than the registration model (it is not associated with the same symbolic status).

However, a key difficulty with ascription is that criteria must be established to identify which relationships will be subject to the regime. It was suggested above that registration schemes tend to be substantively empty and focus on procedural requirements. In contrast, ascription schemes are often associated with stringent criteria. When people disagree as to the status of their relationship, this may necessitate an inquiry into their private lives that may be unwanted and intrusive. People also lack the certainty about their legal status that registered partners possess. A further difficulty with the ascription model is the absence of a consent requirement, which means that people may not consent to the imposition of legal status or realise that they have become subject to certain legal obligations.

For these reasons, registration is often preferred over ascription as a model for recognising personal relationships. However, whether a registration or ascription model is chosen to recognise a particular relationship may be a decision based on politics rather than the suitability of a particular regime. For example, New Zealand and Australia have developed a set of presumptions that grant parental status to same-sex mothers having children through assisted reproductive means in New Zealand and Australia. ${ }^{17}$ This can be contrasted with the more common use of registration models, such as second parent adoption, to gain parental rights for the non-biological parent in lesbian families elsewhere. Graycar and Millbank observe that schemes must be considered: ${ }^{18}$

\footnotetext{
${ }^{16}$ Sotirios Sarantakos "Legal Recognition of Same-Sex Relationships" (1998) 23 Alt LJ 222 at 226.

${ }^{17}$ Reg Graycar and Jenni Millbank "From Functional Family to Spinster Sisters: Australia's Distinctive Path to Relationship Recognition” (2007) 24 JL and Pol'y 121 at 123.

${ }^{18}$ Ibid.
} 
... in their political and legal context. This context helps to explain the wide divergence in approaches between relationship recognition law reform debates in Australia (mainly focusing on presumption-based approaches), and the opt-in forms of recognition, ranging from marriage, civil unions or registered partnerships, that seem to have been far more popular in other jurisdictions.

The creation of a "domestic relationship" under the Domestic Violence Act 1995 is a significant example of the use of the ascription model where recognition does not depend on whether a relationship is conjugal or not. In fact, as outlined in Chapter One, there are many other examples whereby people are ascribed certain rights on the basis of family status, by the use of terms such as "family", "relative" and "sister or brother". Ascription is the primary model used in New Zealand to recognise non-conjugal relationships, although legal recognition often depends on whether people are family members by blood.

There is a particular concern with applying a comprehensive ascription model to non-conjugal relationships, as such a regime may affect those who do not reasonably expect to be subject to such a regime. For example, what if the relationship in question is one of dependency, not interdependency, where an elderly mother is living with her daughter and her daughter's husband? Even where there is a very close relationship and a shared economy of household, is it reasonable to expect parties to assume financial obligations toward each other in the future by reason of their interdependence? Is not the nature of family such that one family member may provide support to another without the creation of legal obligations? Are the rules of equity sufficient to correct any deficiency or is further legal intervention required?

\section{Private Law and Contract \\ $1 \quad$ General features}

Private law operates by default when governments do not provide a legal framework for regulating relationships. Even when there is a framework, people may be able to express their commitments through private law mechanisms unless they are prohibited from contracting out of statutory 
provisions. ${ }^{19}$ Private law remedies include contract, tort, unjust enrichment and constructive trust. Private law is necessarily supported by an underlying legal framework. However, the important point is that people must agree to be bound and may agree as to what being bound will entail (unlike registration where people automatically become subject to rights and duties).

In recent times, it has been suggested that there has been a move from the registration and ascription models to one of private contract. Leib states that: ${ }^{20}$

It is hard in this age to think about legal obligations and liabilities as being based on a "status." Indeed, it is widely accepted that our legal culture - with all progressive societies - has moved away from status toward "contract". This status-to-contract story maintains that the law once held us liable for our social and familial roles but now holds us liable only for social relations to which we consent voluntarily: Under a contract model, we are able to define our own roles more freely and can limit our liabilities successfully by simply withholding our consent from creating binding legal relations in our private social lives.

On one level the notion of employing private law to regulate our relationships is enticing, because of private law's embodiment of the principle of voluntariness. However, as Leib also points out, legal systems are not voluntary, cannot ignore social roles and the law requires many people to perform special duties whether they consent to or not. ${ }^{21}$ The private law model also does not recognise the power imbalances that can exist in personal relationships, which can otherwise result in the subjugation of one party to the other.

In addition, private law remedies are burdensome, costly mechanisms for regulating relationships, and tend to favour the party with greater resources or bargaining power. They do not always recognise the nature of personal relationships, which unlike business relationships, are more likely to require after-the-fact remedies. In these cases, equitable remedies become more important, as parties to a relationship are unlikely to have reached prior

\footnotetext{
${ }^{20}$ Ethan J Leib "Friendship \& the Law" (2006-7) 54 UCLA L Rev 631 at 635 - 636.

${ }^{21}$ Ibid.
} 
contractual agreement. A further problem is that the private law model is typically only binding on parties to the relationship. Some suggest that nonconjugal relationships do not exhibit characteristics that render them appropriate for registration or ascription and are a private law matter. However, outside of property division, it is rights against third parties, such as the state, employers and private service providers, that are particularly important.

Finally, family law is about affective relationships. Austin argues that the modernist de-emphasis on status and emphasis on contractual relations and transactions between autonomous individuals is not necessarily suited to our personal relationships. ${ }^{22}$ He further suggests that: ${ }^{23}$

\begin{abstract}
Most of us are deeply involved in relationships with others - we are sons, daughters, wives, parents, lovers, husbands, significant others, members of iwi and hapu, and now, civil union partners - relationships that, to some extent at least, sublimate our autonomy. Some of these relationships involve contract, but all involve status. They often involve powerfully irrational bonds with others, bonds that make us quite unlike the atomised individual envisaged by the contract side of the progress narrative.
\end{abstract}

It could be suggested that the primary role of private contract in our personal relationships is to allow parties in a conjugal relationship to contract out of the statutory regimes imposed by registration or ascription. Generally, conjugal relationships are not otherwise associated with the private contract model. Nor should the state rely upon private contract to order affairs between intimates. The state has an interest in healthy, strong relationships. Private contract may only satisfy some state objectives and may be inadequate to satisfy others, unless the private ordering aligns with the state's objectives. The Law Commission of Canada suggests that: ${ }^{24}$

\begin{abstract}
Although contracts will continue to remain an important method for individuals to determine their mutual rights and obligations, they are not a sufficient remedy in and of themselves. The contractual model may respect the value of autonomy but often falls short of fulfilling other values such as equality or efficiency since
\end{abstract}

\footnotetext{
${ }^{22}$ Graeme W Austin "Essay: Family Law and Civil Union Partnerships - Status, Contract and Access to Symbols" (2006) 37 VUWLR 183 at 184.

${ }^{23}$ Ibid.

${ }^{24}$ Law Commission of Canada Beyond Conjugality, above n 3, at 115.
} 
too few individuals are prepared to negotiate the terms of their close personal relationships.

Cross, Palmer and Smith suggest that "Many authors propose that private contracts should be the vehicle for re-ordering the way in which benefits are distributed" 25 This view considers that the concerns of people in nonconjugal relationships can be sufficiently addressed by allowing them to privately order their affairs. However, as suggested, these relationships (particularly if they are between elderly cohabitants) may be particularly vulnerable to power imbalances, and private contract is unlikely to address issues which arise.

Moreover, private contract typically only settles matters between parties themselves. Many of the rights at stake in extending rights and responsibilities to non-conjugal partners arise in relation to state or third party support. The Burden sisters' complaint was based on an allegation that the state should not require them to pay inheritance tax. In addition, "it is difficult to anticipate all of the situations in which the legality of kinship arrangements will be relevant." ${ }^{26}$ As such, the private contract model is not sufficient to meet the legal needs of all those in non-conjugal relationships.

\section{Conclusion}

This chapter set out three models for recognising personal relationships: registration (including the marriage model), ascription and private contract. Each of these models has a key defining feature. In the case of registration, this is the act of choosing to register a relationship. For ascription, this is the imposition of rights and responsibilities without express consent. For private contract, this is an agreement between parties which involves parties consenting to each aspect of the law that governs them.

\footnotetext{
25 Jane E Cross, Nan Palmer and Charlene L Smith "Families Redefined: Kinship Groups That Deserve Benefits" (2008-2009) 78 Miss LJ 791 at 811.

${ }^{26}$ Ibid, at 819.
} 
Each of these models also has a different set of characteristics and benefits and risks associated with the way that they recognise our personal relationships. However, it is clear that the private law model is not sufficient to meet the needs of those in non-conjugal relationships. To date, the ascription model has been used most widely to recognise non-conjugal relationships in New Zealand. The following chapter considers the application of the registration and ascription models to non-conjugal relationships in overseas countries. This provides a basis for the final chapter which considers how the legal recognition of non-conjugal relationships in New Zealand may be enhanced. 


\section{CHAPTER FOUR: NEW APPROACHES OVERSEAS}

\section{Introduction}

Within the last decade, some commonwealth and continental countries have developed comprehensive legal frameworks for recognising non-conjugal relationships. Some of these measures would equate to changes in New Zealand law that allowed people in non-conjugal relationships to enter into civil unions or that recognised certain non-conjugal relationships as a type of de facto relationship.

This chapter considers schemes that recognise non-conjugal relationships in a manner similar to marriage or marriage-like relationships and for similar purposes. This provides an opportunity to assess the merits of such schemes and whether New Zealand should adopt this approach. ${ }^{1}$ Recognition schemes are considered by country. The key features of each scheme are identified and the schemes are evaluated against the principles of relationship recognition identified in Chapter One. ${ }^{2}$ The analysis is focused on principles to which these schemes do not appear to give effect.

\section{Australia}

The Australian Capital Territory, New South Wales, Tasmania and Victoria recognise non-conjugal relationships in similar ways to marriage and marriage-like relationships. This reform has taken place in a legal environment where state and territorial recognition of personal relationships is limited by the division of powers between those governments and the federal government.

Under Australian law, the federal government has the power to regulate marriage and governs the recognition of marriages through the Marriage Act $1961 .^{3}$ Successive governments have consistently understood this to mean that

\footnotetext{
${ }^{1}$ An unfocused worldwide survey of individual legal provisions is outside the scope of this thesis. However, the following chapter considers specific examples of recognition in New Zealand.

${ }^{2}$ These are equality and autonomy as overarching principles; personal safety and protection of the vulnerable; freedom of thought, conscience and religion; privacy; and other principles of good policy design, namely efficiency, coherence and certainty.

${ }^{3}$ Commonwealth of Australia Constitution Act 1900, s 51(xxi).
} 
the federal government has the power to determine whether marriage-like relationships are recognised. In 2004, the Marriage Act 1961 was amended to prevent the recognition of same-sex marriages. ${ }^{4}$ Then, in 2006, the Civil Union Act 2006 (ACT) was disallowed under s 35 of the Australian Capital Territory (Self-Government) Act 1988 (Cth), as the federal government considered that it portrayed civil unions as same-sex marriages. ${ }^{5}$

However, this division of powers has not prevented some states and territories from establishing registration schemes for recognising non-conjugal relationships, although these schemes are not recognised by federal law. In fact, there has been some support from the federal government for these measures. In December 2007, the then Prime Minister of Australia announced that the Australian Government would be developing a national relationship register, similar to that in Tasmania (discussed below), which would officially record an existing same-sex relationship. ${ }^{6}$ At the time, he indicated that the register would be used by people in "platonic, dependent relationships".

No national relationship register has yet been established, although the federal government has removed discrimination against unmarried couples in many legal areas. ${ }^{7}$ The federal government's commitment to introducing a national relationship register was reaffirmed on 29 July $2009 .{ }^{8}$ The approach endorsed by the federal government was to encourage all states and territories to create their own relationship registers, based on Tasmania's model, while federal legislation was amended to recognise these relationships. In accordance with this policy, the Relationships Register Act 2010 was passed in New South Wales to allow unmarried couples to register their relationship. However, unlike Tasmania's model, the Act does not recognise non-conjugal relationships.

\footnotetext{
${ }^{4}$ Section 5 of the Marriage Act 1961 defines marriage as "the union of a man and a woman to the exclusion of all others, voluntarily entered into for life."

5 See "Australian government to block gay civil unions" New Zealand Herald (Auckland, 30 March 2006).

6 "Relationship register productive: Rudd" Sydney Morning Herald (Sydney, 16 December 2007).

7 See Attorney-General's Department "Same-Sex Reforms: Overview of the Australian Government's Same-Sex Law Reforms" <www.ag.gov.au>.

${ }^{8}$ AFP/SBS "Rudd rules out gay marriage” SBS (Sydney, 29 July 2009).
} 
Although a new administration is not yet in place following the recent election, it seems unlikely that the federal government will introduce mechanisms to recognise non-conjugal relationships in the near future. However, there are two important points. First, states and territories have the freedom to establish their own regimes (though the application of these regimes may be limited by federal law), provided that these regimes do not resemble marriage. Second, as will be seen throughout this chapter, discussion of recognising non-conjugal relationships tends to occur in the midst of debate about same-sex law reform. The same regimes that recognise non-conjugal relationships are also used to recognise non-traditional conjugal relationships.

\section{A Australian Capital Territory \\ $1 \quad$ "Domestic Relationships"}

The Australian Capital Territory recognises non-conjugal relationships under the Domestic Relationships Act 1994. The Act allows for the adjustment of property interests and the imposition of maintenance obligations where relationships break down. At the time the Act was passed, the Australian Capital Territory did not have legislation in place to deal with property disputes between same-sex couples, although a statutory regime applied to marriages and heterosexual de facto relationships. Millbank writes that: ${ }^{9}$

The Domestic Relationships Act 1994 (ACT) is a unique piece of Australian legislation. It made the Australian Capital Territory the first common law jurisdiction in the world to enact a regime for dividing property on relationship breakdown to relationships beyond marriage and heterosexual de facto couples. The Act did not limit eligibility to heterosexual couples, cohabitees, or couples at all.

The Act applies to two people who terminate their "domestic relationship", which is: ${ }^{10}$

A personal relationship between 2 adults in which one provides personal or financial commitment and support of a domestic nature for the material

\footnotetext{
9 Jenni Millbank "Domestic Rifts: Who is Using the Domestic Relationships Act 1994 (ACT)?" (2000) 14 AJFL 1 at 1-2.

${ }^{10}$ Domestic Relationships Act 1994, s 3(1).
} 
benefit of the other and includes a domestic partnership but does not include a

legal marriage.

A domestic partnership is a de facto relationship. ${ }^{11}$ As "domestic relationship" includes, but is not limited to, a domestic partnership, the term clearly includes non-conjugal relationships. The Act expressly contemplates non-conjugal relationships where one person provides "personal or financial commitment and support of a domestic nature." ${ }^{2}$ Cohabitation is not a requirement, as domestic relationships may exist between people who are not members of the same household. ${ }^{13}$ However, relationships involving paid caregiving are not domestic relationships. ${ }^{14}$

\section{Application of relationship recognition principles}

At first glance, the Domestic Relationships Act could appear to promote the principles identified in Chapter One. The Act ensures that property can be fairly distributed when relationships break down, thus promoting equality within relationships. The Act can apply to anyone in a relationship where there is a degree of support or dependency, suggesting that it promotes equality between conjugal and non-conjugal relationships. While the Act imposes obligations without express consent, it does so on the same basis of protecting the vulnerable, as does the Property (Relationships) Act 1976 in New Zealand. Behrens writes that the Domestic Relationships Act provides a: ${ }^{15}$

... means for claiming private support based on dependencies that exist outside (as well as inside) sexual relationships. This is unique legislation and could be said to involve a partial re-envisioning of the notion of 'family'.

However, the Act distinguishes between different types of conjugal relationships, providing expressly that a domestic relationship does not include a marriage. The Act also provides for the adjustment of property interests and maintenance between people who do not cohabit. It is difficult to see how such financial obligations arise in these relationships. Does this approach really

\footnotetext{
${ }^{11}$ Legislation Act 2001 (ACT), s 169.

${ }^{12}$ Domestic Relationships Act 1994, s 3(1).

${ }^{13}$ Ibid, s 3(2)(a).

${ }^{14}$ Ibid, s 3(2)(b).

${ }^{15}$ Juliet Behrens "Book Review: The Neutered Mother, the Sexual Family and Other Twentieth Century Tragedies” (1996) 10 AJFL 272 at 274.
} 
accord with the needs and reasonable expectations of people in such relationships? What was the basis for recognising people in relationships who provide personal or financial support of a domestic nature and how has the Act affected these relationships?

To answer the last question, there is limited research available regarding the operation of the Act. However, Millbank undertook a court file search to profile those people who had used the Act in the first five years of its operation. $^{16}$ As only one case had been reported under the Act, Millbank conducted a case file search and found that of the 237 relevant court files identified, only seven cases concerned litigants who would have been excluded by traditional de facto relationship legislation. ${ }^{17}$ Of these, only one matter involved a "non-couple", a heterosexual couple and a friend who had purchased property together. Millbank considered that the low uptake by non-couples and non-cohabitees could not be explained without further research, but indicated: ${ }^{18}$

... that this research suggests we do not need to be as worried about noncouples and non-cohabitees in laws concerning property division, because such groups are simply less likely to jointly own or contribute to property than couples.

Ultimately, the Act was not crafted to recognise the living arrangements and needs of those in non-conjugal relationships. Millbank considered that the focus of the Act upon "carers", which had been a key issue during debates on the Bill, was misguided. ${ }^{19}$ There were no cases of caregivers using the Act and Millbank considered that the possibility of a carer making a claim on a property, or a Court ordering that a carer had such a claim prior to the death of the owner, was unlikely. In fact, Millbank's research revealed that the main use of the Act was as a means of transferring property without attracting stamp duty, which provided a major incentive to seek an order under the Act, even if there was no disagreement between parties. ${ }^{20}$

\footnotetext{
${ }^{16}$ Jenni Millbank "Domestic Rifts”, above n 9.

${ }^{17}$ Ibid, at 8

${ }^{18}$ Ibid, at 46 .

${ }^{19}$ Ibid, at 46-47.

${ }^{20}$ Ibid, at 13. Stamp duty is a tax that is levied on documents.
} 
If the available research indicates that there was no need to extend the provisions of this Act to include non-conjugal relationships, why did this occur? In reality, this Act establishes a regime that applies to de facto couples. There is little doubt that the primary impetus was to provide a mechanism for dealing with property claims between same-sex couples that was palatable to conservative factions at the time the Act was passed. During debate on the Bill it was observed that: ${ }^{21}$

\footnotetext{
Persons involved in a formal marriage, of course, have had the protection of the Family Law Act for nearly 20 years ... Other jurisdictions have enacted legislation in respect of de facto relationships - marriages except for the formality of a marriage ceremony - and the ACT has lacked that in the past. This is an attempt to remedy that ...
}

In support of the Bill, it was also suggested that it was important not to deny a group in need assistance on the basis of "irrelevant considerations", such as whether there was a sexual relationship between parties. ${ }^{22}$ Millbank also notes that there were two original categories of relationships proposed in the draft legislation: de facto and "other personal relationships". These categories were later collapsed, as it was not considered appropriate to "distinguish on the basis of gender". 23

As such, the recognition of non-conjugal relationships under this Act was not based on an identifiable need to grant legal status to these relationships in a manner akin to the recognition of marriage. Rather it was a strategy to give same-sex couples status and rights without expressly acknowledging the conjugal nature of these relationships. When the Australian Capital Territory considered the establishment of same-sex civil partnerships in 2005, the Department of Justice and Community Safety stated, in respect of recent social legislation including the Domestic Relationships Act that: ${ }^{24}$

\footnotetext{
${ }^{21}$ (19 May 1994) ACTPD 1800-1801.

22 (21 April 1994) ACTPD 1117.

${ }^{23}$ Millbank "Domestic Rifts", above n 9, at 18.

24 ACT Department of Justice and Community Safety The Recognition of Same Sex Relationships in ACT (2005) at 5.
} 
The overall result of these reforms was to extend the rights of same sex couples into an increasing number of legal areas, on the basis of equality with rights of unmarried opposite sex couples.

Overall, this Act does not further the equality of non-conjugal relationships because it does not address any identifiable needs of people in such relationships. It also sustains the distinction between different types of conjugal relationship, continuing to privilege marriage. It remains unclear what type of non-conjugal relationships are covered by the concept of a relationship involving a "personal or financial commitment and support of a domestic nature" and Millbank's research suggests it is unlikely that a court will ever be called on to decide this.

There is no need for New Zealand to adopt such an approach to recognising non-conjugal relationships, because New Zealand already allows for the adjustment of property interests between people who do not come within the Property Relationships Act 1976 on the basis of the doctrine of constructive trust. $^{25}$ This doctrine focuses on the reasonable expectations of parties and looks at whether they have contributed to the property in some way, whether they have a reasonable expectation that they would acquire an interest, and whether the property owner should reasonably have expected to grant the other person an interest in that property. Situations may arise where cohabitants disagree about their respective interests in property upon relationship breakdown. However, the courts have a broad equitable jurisdiction to determine ownership in such cases.

\section{B New South Wales \\ 1 "Domestic Relationships"}

Five years after the Australian Capital Territory passed the Domestic Relationships Act 1994, New South Wales passed the Property (Relationships) Legislation Amendment Act 1999. This Act amended the Property (Relationships) Act 1984 to grant a narrow range of non-conjugal relationships

\footnotetext{
${ }^{25}$ The Law Commission of England Sharing Homes: A Discussion Paper (2002) at 66.
} 
some limited rights relating to property division as well as recognising de facto relationships in gender-neutral terms. ${ }^{26}$

While the Amendment Act was based on the Domestic Relationships Act, New South Wales first considered recognising non-conjugal relationships a decade prior in a Law Commission report on de facto relationships. ${ }^{27}$ The Commission preferred not to extend its recommendations to "other domestic or household relationships, such as those constituted by parents and adult children, siblings, homosexual couples, or larger groups living in a common household." The Commission considered that while de facto relationships partially resembled marriage, these other types of relationships bore less resemblance.

Then, in 1993, the Gay and Lesbian Rights Lobby in New South Wales released an initial discussion paper recommending that people be able to nominate "significant personal relationships" for particular purposes. ${ }^{28}$ The paper suggested that caregiving relationships and other forms of emotional or financial interdependent relationships raise different policy concerns than couple relationships. It proposed that different people might be nominated as the person with whom someone has a significant personal relationship, for different purposes. It questioned why certain rights and responsibilities flow from marriage and why marriage continues to be viewed as the benchmark. However, the Lobby resiled from this position in the final version of the paper released in 1994, indicating that the proposal of being able to nominate more than one person was too difficult to implement. ${ }^{29}$

The 1999 amendment to the Property (Relationships) Act, which followed, allows for the recognition of couple relationships and non-couple relationships under the umbrella term of "domestic relationship". Section 5 defines a domestic relationship as a de facto relationship (defined in s 4) or:

... a close personal relationship (other than a marriage or a de facto relationship) between two adult persons, whether or not related by family,

\footnotetext{
${ }^{26}$ Prior to this amendment, the Property Relationships Act 1984 was titled the De Facto Relationships Act 1984.

${ }^{27}$ New South Wales Law Reform Commission De Facto Relationships (NSWLRC R 36, 1983). at 15 .

${ }^{28}$ Lesbian and Gay Legal Rights Service "The Bride Wore Pink" (1993).

${ }^{29}$ Lesbian and Gay Legal Rights Service "The Bride Wore Pink" (2 ${ }^{\text {nd }}$ ed, 1994).
} 
who are living together, one or each of whom provides the other with domestic support and personal care.

As such, the Act is of similar scope to the Domestic Relationships Act 1994 and covers the adjustment of property interests and maintenance obligations. However, unlike the Australian Capital Territory, New South Wales maintains a distinction between couple and non-couple relationships and uses a narrower definition of domestic relationships, excluding non-cohabitees. Bottomley and Wong suggest that "lesser rights" accord to non-couple relationships. ${ }^{30}$ Writing shortly after the passage of the Amendment Act, Graycar and Millbank noted that only a small number of Acts were consequentially amended to refer to a "domestic relationship" (in the areas of statutory property division, inheritance, bail and stamp duty), while a much larger number refer to a "de facto relationship". 31

\section{$2 \quad$ Application of relationship recognition principles}

Like the Domestic Relationships Act, the real focus of the New South Wales legislation is on recognising non-traditional conjugal relationships without referring to their conjugal nature. During Parliamentary debate on the Bill one politician asserted that: ${ }^{32}$

If this bill were about sexuality I would not be able to support it. However, as no-one is arguing that this bill is about sexuality, I will not oppose it.

Ultimately, the Act raises concerns similar to the Domestic Relationships Act in respect of the application of the relationship recognition principles; in particular, equality, the protection of reasonable expectations, and the principles of good public policy design, including efficiency, coherence and certainty. Of the uptake by non-conjugal partners, the New South Wales Law Reform Commission has observed that: ${ }^{33}$

\footnotetext{
${ }^{30}$ Anne Bottomley and Simone Wong Changing Contours of Domestic Life, Family and Law: Caring and Sharing (Hart Publishing, Oxford, 2009) at 20.

${ }^{31}$ Reg Graycar and Jenni Millbank "The Bride Wore Pink ... To the Property (Relationships) Legislation Amendment Act 1999: Relationships Law Reform in New South Wales" (2000) 17 Can J Fam L 227 at 249.

32 (26 May 1999) NSWPD 739.

${ }^{33}$ New South Wales Law Reform Commission Relationships (NSWLRC 113, 2006) at 3.7
} 
There have been very few cases brought by people in close personal relationships. In fact, in most cases where the existence of a close personal relationship is claimed, the claim is presented as an alternative argument. The primary cause of action is usually that the applicant was in a de facto relationship with the defendant or, in the case of matters under the Family Provision Act 1982, the deceased.

This report followed a review by the Commission of the operation of the Act. $^{34}$ An initial discussion paper in 2002 queried whether de facto and close personal relationships should continue to be regulated by the same provisions. ${ }^{35}$ The discussion paper stated that: ${ }^{36}$

... de facto relationships and close personal relationships can be vastly different in nature, and people may form such relationships for very different reasons ... In general, the provisions of the PRA assume some degree of emotional and financial interdependence in a relationship. While this is usually the case in de facto relationships, it may not be so in other close personal relationships.

The Commission also considered whether the cohabitation requirement should be removed from the Property (Relationships) Act, but raised a concern that this: $:^{37}$

... could have the significant disadvantage of making it difficult to determine when a close personal relationship exists. This could result in relationships where there is only a tenuous emotional or financial interdependency, which could cause injustice.

The 2006 report by the Law Commission, however, supported the continued application of the law to non-conjugal relationships. ${ }^{38}$ In fact, it recommended removing any hierarchy in legislation that attaches greater rights to some relationships than others and extending all the rights of marriage to close personal relationships (both conjugal and non-conjugal). The report observes that, while the legislation is somewhat unclear, it is intended to apply

\footnotetext{
${ }^{34}$ Reg Graycar and Jenni Millbank "The Bride Wore Pink", above n 31, at 228.

${ }^{35}$ New South Wales Law Reform Commission Review of the Property (Relationships) Act 1994 (NSW) (NSWLRC DP 44, 2002).

${ }^{36}$ Ibid, at 2.58 to 2.59 .

${ }^{37}$ Ibid, at 2.67 .

${ }^{38}$ New South Wales Law Commission Relationships, above n 33, at 1.56.
} 
to carers. ${ }^{39}$ The report also highlighted some case law on the meaning of "close personal relationship", which includes both domestic and personal support, where: ${ }^{40}$

Domestic support includes such things as doing the shopping for the parties, cooking, washing and providing accommodation, etc. Personal care, on the other hand, implies care of a more private nature such as assistance with bodily functions and personal hygiene: for example, dressing and undressing, bathing, food preparation and eating, taking medication ... one might expect this kind of care from an employed nurse or carer, or a mother for her sick child or a daughter for her elderly incapacitated mother. While the paid nurse or carer would be excluded by the terms of the Act, the mother or daughter in the last two examples would be included.

In a recent case, it was held that taking the deceased to doctor's appointments and keeping him company was not sufficient. The plaintiff did not provide any evidence that she provided assistance by way of feeding, clothing or showering, or administering medication to the deceased, therefore no close personal relationship was found to exist. By contrast, in Jurd v Public Trustee, apart from cooking, cleaning and keeping the property tidy for the deceased, the plaintiff claimed also to have bathed the deceased's feet, brushed his hair and cajoled him into bathing etc. The deceased was very obese and suffered from diabetes and emphysema. The Supreme Court found that the elements of a close personal relationship had been met, although the relationship was one of short duration.

In 2010, New South Wales enacted the Relationships Register Act 2010 allowing for more comprehensive recognition of same-sex relationships. However, this Act is not intended to include people in non-conjugal relationships as two people are excluded from registering their relationship "if ... the adults are related by family." 41

Greycar and Millbank observe that, unlike overseas approaches, the initial focus in Australia toward recognising same-sex relationships was on presumption-based (ascription) regimes, rather than registration schemes. ${ }^{42}$ Most likely this was due to the symbolic nature registration schemes (conferring

\footnotetext{
${ }^{39}$ New South Wales Law Commission Relationships, above n 33, at 3.5 - 3.6.

${ }^{40}$ New South Wales Law Commission Relationships, above n 33, at 3.8 -3.10.

${ }^{41}$ Relationships Act 2010, s 5.

${ }^{42}$ Reg Graycar and Jenni Millbank “The Bride Wore Pink”, above n 31, at 228.
} 
a great degree legitimacy on relationships they recognise), making it more politically palatable to accord recognition through ascriptive regimes that also recognise other caring relationships. However, following these reforms, Tasmania introduced both comprehensive registration and ascription regimes for recognising conjugal and non-conjugal relationships.

\section{Tasmania}

\section{$1 \quad$ "Significant" and "caring relationships"}

Tasmania is one of Australia's more conservative provinces. Tasmania was the last state or territory in Australia to decriminalise sexual acts between consenting males, passing amending legislation in 1997. However, Tasmania now recognises same-sex relationships under the Relationships Act 2003. This Act also recognises non-conjugal relationships. In fact, no state or territory in Australia yet rivals the extent of the recognition of non-conjugal relationships afforded under this Act.

The Relationships Act allows a deed of relationship to be registered as either a "significant relationship" or a "caring relationship" when certain conditions are satisfied. ${ }^{43}$ Unlike the reforms in the Australian Capital Territory and New South Wales, registration of a relationship under the Relationships Act is not limited to the adjustment of property interests and has many significant legal consequences.

To begin with, however, significant relationships are not intended to include non-conjugal relationships. People who register their relationship as a significant relationship cannot be "related by family" and must have a "relationship as a couple". ${ }^{44}$ Registration of a relationship is not essential to recognise it as a significant relationship. Rather, participants must meet criteria traditionally associated with the recognition of de facto relationships.

Caring relationships, on the other hand, are intended to include nonconjugal relationships. Two adults, related or not, can register a caring relationship if one provides the other with "domestic support and personal

\footnotetext{
${ }^{43}$ Relationships Act 2003, ss $4-5$.

${ }^{44}$ Ibid, s 4.
} 
care". ${ }^{45}$ Neither partner can be receiving payment for the care of the other. ${ }^{46}$ Registration is not required for a relationship to be recognised as a caring relationship and a Court can make a declaration that a significant or caring relationship exits between two people upon an application for the purpose by any person. A non-exhaustive list of factors are set out that can be taken into account when deciding whether a relationship is a caring relationship or not.

The lists of criteria used to identify significant and caring relationships respectively, are similar. Three additional factors are included in the identification of a significant relationship, the first two of which are whether or not a sexual relationship exists and the care and support of children. In addition, participants must also have a relationship as a couple. A caring relationship, otherwise, involves the same criteria as a significant relationship. That is, regard may be had to the duration of the relationship; the nature and extent of a common residence; the degree of financial dependence or interdependence, and arrangements for support between the parties; the ownership, use and acquisition of property; the performance of household duties; the degree of commitment to a shared life; and the reputation and public aspects of the relationship. An additional factor only relates to caring relationships, which is the level of personal care and domestic support provided by one or each of the partners to the other.

The Relationships Act extends the rights, entitlements and responsibilities of opposite-sex married and de facto couples to a wider variety of personal relationships. Both caring and significant relationships have legal consequences for superannuation, taxation, insurance, health care, hospital visitation, wills, property division, and employment conditions (such as parenting and bereavement leave). However, caring relationships entail fewer legal consequences, particularly where they are not registered.

The Relationships Act 2003 itself provides for the adjustment of property interests and maintenance upon dissolution of a caring or significant relationship. All other changes were implemented through the Relationships

\footnotetext{
${ }^{45}$ Ibid, s 5.

${ }^{46}$ Ibid, s 4.
} 
(Consequential Amendments) Bill. ${ }^{47}$ Many of the changes only apply to significant relationships and more apply to registered caring relationships than de facto caring relationships.

Finally, a deed of relationship may be revoked on the death or marriage of either party or on the application of either or both of the parties. To enter into either a significant or caring relationship, both parties must live in Tasmania. It does not appear that any country recognises Tasmanian caring relationships, although some countries recognise Tasmanian significant relationships as the equivalent of same-sex partnerships in those countries. ${ }^{48}$

\section{$2 \quad$ Application of relationship recognition principles}

The proposal to reform Tasmania's relationship laws by recognising both conjugal and non-conjugal relationships occurred in the midst of significant debate about same-sex law reform. However, the recognition of significant and caring relationships was the result of an inquiry into the legal recognition of significant personal relationships by the Tasmanian Parliament's Joint Standing Committee on Community Development in 2001 . $^{49}$

The Committee found that the denial of legal recognition to same-sex relationships created unjustifiable hardship and expenses and that discrimination against these relationships occurred in many areas of life. ${ }^{50}$ The Committee recommended extending the legal definition of de facto relationship (which only applied to heterosexual couples) or using a new term such as domestic relationship or significant personal relationship, as well as allowing such relationships to be registered. ${ }^{51}$ The Committee reported that only "a small number of submissions referred to carer or other non-traditional relationships

\footnotetext{
${ }^{47}$ The Bill was split into many different amending Acts prior to passage.

${ }^{48}$ For example, England recognises significant relationships as equivalent to civil partnerships under the Civil Partnership Act 2004, and the State of New Jersey recognises significant relationships as equivalent to domestic partnerships, but not civil unions.

${ }^{49}$ Parliament of Tasmania: Joint Standing Committee on Community Development Report on the Legal Recognition of Significant Personal Relationships (2001) at 5.

${ }^{50}$ Ibid.

${ }^{51}$ Ibid.
} 
which were not of a sexual nature. ${ }^{, 52}$ However, the Committee considered that: ${ }^{53}$

... such relationships arise in response to individual circumstances and thus do not readily identify as a cohesive interest group, therefore a lesser response was to be expected from this category.

The submission of the Tasmanian Anti-Discrimination Commissioner raised the issue of two elderly companions living together and perceived flaws with intestacy law. ${ }^{54}$ The Commissioner noted that even if the two people are financially independent, the fact that they are living together often means they are contributing, whether it is in psychologically-supportive ways or monetary or non-monetary ways, to whatever property is accumulated. The Committee found that: ${ }^{55}$

Like same sex couples, those in non-marriage like relationships are disadvantaged in areas of property rights, intestacy and other entitlements. These relationships, which may include carer and companion relationships, have been recognised in the ACT, NSW and Victoria. However they do not receive the full range of rights afforded to non-traditional relationships based on sexual association.

The Committee considered that while “... the term 'de facto' may seem incongruous when used in respect to non-couple relationships, the presumptive model of recognition can be utilised to recognise relationships which are not 'marriage-like'."56 Previously, a Private Member's Bill, the Significant Relationships Bill (No 2) 1998, had sought recognition of significant personal relationships in the same way as de facto relationships, referencing a variety of factors such as emotional interdependence, mutual fellowship, and mutual commitment to the continuance of the relationship, noting that these relationships might or might not be based on cohabitation and sexual association or financial interdependence. The Committee endorsed this approach.

\footnotetext{
${ }^{52}$ Ibid, at 21.

${ }^{53}$ Ibid.

${ }^{54}$ Ibid, at 26.

${ }^{55}$ Ibid, 25-26.

${ }^{56} \mathrm{Ibid}$, at 64 .
} 
However, the concerns raised in this inquiry with respect to the recognition of non-conjugal relationships have not been borne out in practice. Data provided by the Tasmanian Department of Justice in 2009 indicated that 145 relationships had been registered in total since the Act came into force in 2004. Out of these, only two were caring relationships. ${ }^{57}$ For Tasmania as well then, recognition of non-conjugal relationships was an accompaniment to samesex law reform, whereby non-conjugal relationships were not recognised in their own right but to support the extension of legal recognition to same-sex couples. Croome writes that: ${ }^{58}$

Some supporters of conjugal/non-conjugal equality have insisted on its pragmatic value. Many of those conservatives who are fearful of endorsing the rights of same sex couples are less worried by law reform proposals which mix these couples in with a much broader range of significant relationships.

Ultimately, the Tasmanian reforms also raise questions about the principled basis for extending a comprehensive recognition model based on marriage to non-conjugal relationships. Similar questions about the application of the relationship recognition principles apply as were raised in relation to the Australian Capital Territory and New South Wales schemes.

\section{Victoria}

1 "Registered caring relationships"

Victoria has also enacted legislation that recognises certain non-conjugal relationships in a manner similar to marriage. To begin with, in 2007, both the Cities of Melbourne and Yarra launched Relationship Declaration Programmes, which remain in force to date. Under these programmes, two people can declare that they are partners and have this declaration recorded in the respective Council Relationship Declaration Registers (for example, for the purposes of establishing that a relationship exists). Victoria then introduced the Relationships Bill in December 2007 to create a state-wide domestic partnership registry. The Bill was enacted in April 2008 and commenced in December 2008.

\footnotetext{
57 Email from Department of Justice to Lorraine Johns regarding the number of caring relationships registered with the Department (15 October 2009).

${ }^{58}$ Rodney Croome "Word is Out" (2007) <www.arts.usyd.edu.au>.
} 
The registration scheme initially applied to same and opposite-sex de facto couples. Although the Tasmanian model of significant and caring relationships was considered during the passage of the Bill, the category of "caring relationships" was not included. However, the Attorney-General stated in the second reading speech that this would be "the subject of further consultation with a view to considering possible amendment in the future". 59 Section 5 defined a registrable relationship as:

\footnotetext{
A relationship (other than a registered relationship) between two adult persons who are not married to each other but are a couple where one or each of the persons in the relationship provides personal or financial commitment and support of a domestic nature for the material benefit of the other, irrespective of their genders and whether or not they are living under the same roof.
}

Despite the requirement for parties to be "a couple", the Act also provides that people who provide paid care cannot register a relationship. This would seem unnecessary if the scheme only applied to "couples". The Act also did not expressly exclude blood relatives from its ambit, as is usually the case where legislation is intended to recognise conjugal relationships only. This might have begged the question as to whether people in a caring relationship would nonetheless attempt to register their relationship under the Act. However, the Relationships Amendment (Caring Relationships) Bill was introduced to provide for the registration of caring relationships in Victoria and the adjustment of property interests and rights to maintenance between caring partners who are in or have been in a caring relationship. The Bill amended the Relationships Act to provide that a registered relationship means a registered domestic relationship (a conjugal relationship) or a registered caring relationship.

There are no functional criteria that must be met in order to register a domestic or caring relationship. The key difference between an application to enter a domestic relationship and an application to enter a caring relationship is that to enter a registered caring relationship both parties to the relationship must

${ }^{59}$ (6 December 2007) VPD 4393. 
receive independent legal advice. Registration under the Act provides conclusive proof of a relationship.

\section{$2 \quad$ Application of relationship recognition principles}

The Relationship Declaration Programmes are unusual types of registration schemes, as they have no substantive legal effect. Rather, their purpose was to make it easier to establish whether a non-traditional conjugal relationship existed prior to legislative reform in Victoria. The legislative reform itself raises similar concerns with respect to the application of the relationship recognition principles identified in relation to the Australian Capital Territory, New South Wales and Tasmania. In fact, partners entering into a caring relationship are required to obtain independent legal advice due to a concern that they will be less likely than domestic partners to expect legal consequences to attach to their relationship.

Two people are not be able to register their caring relationship if married. Interestingly the Scrutiny of Acts and Regulations Committee, in vetting the legislation, suggested that this might amount to discrimination against married people, on the basis that this approach toward recognising caring relationships treated single persons differently from married couples. ${ }^{60}$ The Committee observed that: ${ }^{61}$

For example, a middle-aged person may provide significant care for a disabled friend. If both are single, they will be able to register that relationship, allowing easy proof of that relationship and access to the property adjustment regime in part 3 of the Relationships Act 2008. However, if the one happens to be married (e.g. to a long-term spouse with dementia who is living in a nursing home) or has an intimate relationship with a neighbour, then they will both be denied these legal benefits in respect of their caring relationship

Ultimately, the effect of the Victorian legislation is similar to that of the other Australian examples. It is not clear whether this legislation has, in fact, assisted those in non-conjugal relationships. The ability to register a caring

\footnotetext{
${ }^{60}$ Scrutiny of Acts and Regulations Committee Alert Digest No 15 of 2008 (2008).

${ }^{61}$ Ibid.
} 
relationship commenced on 1 December 2009. To date, none have been registered. $^{62}$

\section{Canada}

The federal and provincial power divide has driven the recognition of non-conjugal relationships in Canada even more so than in Australia. It is now settled law in Canada that the power to define marriage lies with the federal government. ${ }^{63}$ Canada became the fourth country in the world to recognise same-sex marriage with the passage of the Civil Marriage Act 2005. Before this, same-sex marriage was legalised as a consequence of court cases in many provinces and territories, whereby provincial and territorial courts ruled bans on same-sex marriage unconstitutional. ${ }^{64}$

However, prior to the legalisation of same-sex marriage, two Supreme Court cases affirmed the right of de facto couples, including same-sex couples, to equal treatment under the Constitution Act 1982. ${ }^{65}$ First in 1995, in Miron v Trudel, the Supreme Court ruled that marital status was a characteristic which could not be a basis for discrimination, holding that an insurance benefit provided only to married couples discriminated against common law couples. ${ }^{66}$ Then in 1999, in $M v H$, the Supreme Court ruled that same-sex couples were entitled to receive many of the legal benefits associated with marriage. ${ }^{67}$

Most Canadian laws which affect couples are within provincial and territorial, rather than federal jurisdiction. Provinces and territories were, therefore, required to ensure their laws were consistent with these Supreme Court rulings. Bala observes that debate in Canada over the legal recognition of

\footnotetext{
${ }^{62}$ Email from the Victorian Registry of Births, Deaths and Marriages to Lorraine Johns regarding the number of caring relationships registered with the Registry (25 August 2010).

${ }^{63}$ Constitution Act 1867, s 91(26). This interpretation of the constitution was upheld in Reference Re Same-Sex Marriage [2004] 3 SCR 698. Section 92(12) of the Constitution Act gives the provinces the power to pass laws regulating the solemnisation of marriage.

${ }^{64}$ See generally $M v H[1999] 2$ SCR 3.

${ }^{65}$ The Constitution of Canada is defined in subsection 52(2) of the Canada Act 1982 as consisting of the Canada Act (schedule B of the Canada Act sets out the Constitution Act 1982, which includes the Canadian Charter of Rights and Freedoms), all acts and orders referred to in the schedule (including the Constitution Act 1897) and any amendments to these acts and orders.

${ }^{66}$ Miron v Trudel [1995] 2 SCR 418.

${ }^{67} \mathrm{M} v \mathrm{H}$, above $\mathrm{n} 64$.
} 
same-sex marriages and de facto relationships has been accompanied by a proposal that the law should recognise any adult relationship that involves some degree of economic interdependence and close emotional ties. ${ }^{68}$

The response of both Alberta and Nova Scotia to the Supreme Court rulings was to establish legal schemes that recognise non-conjugal relationships. Both provinces now recognise same-sex marriage as a consequence of the Civil Marriage Act. However, the schemes established to recognise non-conjugal relationships remain in force and are discussed below.

New Brunswick also recognises non-conjugal relationships in a very limited manner as a "family relationship". Support obligations under the Family Services Act 1980 arise when two persons, not being married to each other, have cohabited continuously in a family relationship for three years and one person was substantially dependent on the other for support. ${ }^{69}$ Family relationship is not defined in the Act although "cohabit" is defined as living together in a family relationship and "common-law partner" means a person who "cohabits in a conjugal relationship with another person if the persons are not married to each other.,"70

As such, a family relationship is broader than a relationship with a common law partner or spouse. The effect of this measure is limited as it relates to a single provision that "Every spouse has an obligation to provide support for himself or herself and for the other spouse, in accordance with need, to the extent that he or she is capable of doing so."71 The Act was amended to extend this provision from spouses to include family relationships. This approach is notable for the characterisation of non-conjugal relationships as family relationships. Section 114 of the Act also provides an obligation, in accordance with need, for every adult child to maintain his or her parents who have cared for that child and provided support, to the extent that the child is able to do so.

\footnotetext{
${ }^{68}$ Nicholas Bala "Controversy over Couples in Canada: The Evolution of Marriage and Other Adult Interdependent Relationships” (2003-2004) 29 Queens LJ 41 at 88.

${ }^{69}$ Family Services Act 1980, s 112(3).

${ }^{70}$ Ibid s 1.

${ }^{71}$ Ibid, s 112(1).
} 


\section{A Alberta \\ 1 "Adult interdependent relationships"}

Alberta recognises non-conjugal relationships in a manner similar to marriage through the Adult Interdependent Relationships Act 2002. The Act followed two projects by the Alberta Law Reform Institute concerning the recognition of de facto relationships. The Institute first considered extending the rights and obligations of married couples to heterosexual de facto couples after the Supreme Court ruling in Miron $v$ Trudel. $^{72}$ The Institute did not include same-sex de facto couples in this project because it did not consider social policy "sufficiently well established" to do so. ${ }^{73}$

However, following the landmark ruling in $M v H$, the Institute released a further report concerning the legal recognition of same-sex relationships. ${ }^{74}$ This report considered a variety of options to ensure that the law in Alberta would be consistent with this ruling, including the creation of a domestic partnership registry allowing any two people to register their relationship and acquire the benefits and obligations of marriage. The Institute suggested that if the goal was to eliminate discrimination, then a domestic partnership registry would be appropriate. $^{75}$ This recommendation was adopted by the legislature and the Adult Interdependent Relationships Act was passed in 2002.

This Act allows two people to register their relationship or have their relationship recognised on an ascriptive basis. The effect of the Act is that an adult interdependent relationship must be considered when determining legal rights and obligations under a variety of laws and policies in Alberta, including financial support, health and other insurance cover, maintenance, domestic violence, the right to sue for wrongful death, the disclosure of personal information and various conflict of interest provisions.

\footnotetext{
${ }^{72}$ Alberta Law Reform Institute Family Law Project: Spousal Support (DP 18.2, 1998). Miron $v$ Trudel, above n 66.

${ }_{74}^{73}$ Alberta Law Reform Institute Spousal Support, above n 72, at footnote 274.

74 Alberta Law Reform Institute Recognition of Rights and Obligations in Same-Sex Relationships (RP 21, 2002). MvH, above, n 64.

${ }^{75}$ Ibid, at 41.
} 
With respect to registration of the relationship, s 3 provides that a person is the adult interdependent partner of another if they enter into an adult interdependent agreement under s 7 . Section 7 allows two people to register their relationship if they are living together or intend to live together.

With respect to the ascription of relationship status, s 3 of the Act provides that a person is the adult interdependent partner of another if they have lived with the person in a relationship of interdependence for three years or more. ${ }^{76}$ A relationship of interdependence means that the two people share each other's lives, are emotionally committed to one another and "function as an economic and domestic unit". ${ }^{77}$ Section 1(2) of the Act provides that in determining whether two persons function as an economic and domestic unit, all the circumstances of the relationship must be taken into account, which may include:

- whether or not the persons have a conjugal relationship;

- the degree of exclusivity of the relationship;

- the conduct and habits of the persons in respect of household activities and living arrangements;

- $\quad$ the degree to which the persons hold themselves out to others as an economic and domestic unit;

- the degree to which the persons formalise their legal obligations, intentions and responsibilities toward one another;

- the extent to which direct and indirect contributions have been made by either person to the other or to their mutual well-being;

- the degree of financial dependence or interdependence and any arrangements for financial support between the persons;

- $\quad$ the care and support of children; and

- the ownership, use and acquisition of property.

The criteria for identifying whether an adult interdependent relationship exists are essentially the same as those used in New Zealand to identify whether

\footnotetext{
${ }^{76}$ This criterion is relaxed to a relationship of "some permanence" if there is a child of the relationship by birth or adoption.

${ }^{77}$ Adult Interdependent Relationships Act 2002, s 1(1)(f).
} 
a de facto relationship exists, except for the New Zealand requirement that the two people in question live together as a couple. "Conjugality" is a relevant factor, but it is not determinative. It is not clear what conjugality means in this context, although, conceptually, it could be understood to refer to sexual intimacy.

2 Application of relationship recognition principles

The Alberta Law Reform Institute considered that a domestic partnership registry: ${ }^{78}$

... gives effect to many fundamental principles: voluntariness, in that people may choose to assume the benefits and obligations of marriage; fairness between parties in a committed relationship involving issues which arise at the termination of the relationship, where one party is in a more vulnerable position and is in need of protection; minimizing discrimination in access to social status; equity in distribution of benefits; equality among family relationships; and protection of privacy.

However, as Bala suggests “Alberta's political decision to move towards reducing the significance of conjugality is clearly not motivated by any desire to de-emphasize the importance of heterosexual marriage., ${ }^{, 79}$ Bailey observes that Alberta has a history of resisting gay rights, and has been careful to couch its legislative proposals in language that will not offend. ${ }^{80}$ Bailey also indicates that the Act's application is limited and it does not address important issues relating to family property rights. ${ }^{81}$

In addition, the legislation was amended prior to enactment to ensure that people related by blood or adoption could only become adult interdependent partners if they entered into a written agreement. This was to ensure that the reasonable expectations of family members living with each other could not be subverted if one member, upon relationship breakdown, claimed they had been adult interdependent partners. This suggests that the regime does not, in fact, accord with the reasonable expectations or living

\footnotetext{
${ }^{78}$ Alberta Law Reform Institute Same-Sex Relationships, n 72, at 38.

${ }^{79}$ Nicholas Bala “Adult Interdependent Relationships", above n 66, at 89.

${ }^{80}$ Martha Bailey (2004) "Regulation of Cohabitation and Marriage in Canada" Law \& Pol'y 153 at 164 .

${ }^{81}$ Ibid, at 163-4.
} 
arrangements of people in non-conjugal relationships. According to the Alberta Ministry of Agriculture, Food and Rural Development: ${ }^{82}$

Non-conjugal friends living together in a relationship of interdependence for a continuous period of not less than three years will become adult interdependent partners, whether or not they intend to ... it is not possible to contract out of the Dependants Relief Act. Thus, if two elderly friends ... live together in a platonic relationship for several years, when one dies, the other may be able to claim a larger share of the deceased's estate than any surviving children, even if the two friends never signed an adult interdependent partnership agreement.

Although this concern only applies to non-relatives, Davies considers that there is a real risk that cases may arise where a court finds that an adult interdependent relationship existed after three or more years of living in a nonconjugal relationship. ${ }^{83}$ This could undermine the autonomy of parties involved. It is difficult to determine whether this has occurred, as cases taken under the Act appear to all relate to traditional de facto partners. However, Bala states that: ${ }^{84}$

... while it is theoretically possible that non-conjugal cohabitants might find that they have many of the rights and obligations of "spouses", in reality the A.I.R.A. is generally likely to result only in opposite-sex and same-sex conjugal partners having, after three years of cobhatitaiton or after having had a child together, most of these rights and obligations.

As there is no central repository for those who formally enter into an adult interdependent relationship, neither the Alberta Ministry of Justice nor Statistics Alberta collect data on adult interdependent relationships and it is difficult to determine whether there has been any uptake by non-conjugal partners.

\footnotetext{
${ }^{82}$ Ministry of Agriculture, Food and Rural Development Adult Interdependent Partners and Farm Estate Planning (2004).

83 Christine Davies "The Extension of Marriage-Like Rights and Obligations Beyond Conjugality: The Adult Interdependent Relationships Act of Alberta" (Conference of the International Society of Family Law, June 2003).

${ }^{84}$ Nicholas Bala “Adult Interdependent Relationships”, above n 66, at 93.
} 


\section{B Nova Scotia}

\section{$1 \quad$ "Registered partnerships"}

Nova Scotia introduced a domestic partnership registry in $2001 .^{85}$ This registry appears to be based on the British Columbia Law Institute report on recognising spousal and family relationships (although this report was never implemented in British Columbia). ${ }^{86}$

In 1997 the British Columbian Attorney-General directed the Law Institute to review the province's laws that denoted a spousal or family relationship and make recommendations for changes necessary to recognise a variety of family relationships and identify relevant legal rights and obligations. ${ }^{87}$ On the basis of analysis drawing on principles similar to those in Chapter One, the Institute recommended that the law also recognise the family status of people (including non-relatives) who live together in a close relationship that is the equivalent of a family relationship. ${ }^{88}$

The Institute proposed that a non-relative who is regarded as a family member should qualify as such in legislation that governs, for example, insurance protecting a person's family; rights and obligations of a family when a member becomes incompetent; who may own shares in a professional corporation; and who should be considered to be related for the purposes of determining whether someone is in a conflict of interest or whether a transaction between two people is at arm's length. ${ }^{89}$ It is likely that the Institute's recommendations were never enacted because the Institute was not asked to

\footnotetext{
${ }^{85}$ Vital Statistics Act, RS, Ch 494.

${ }^{86}$ Alberta Law Reform Institute Same-Sex Relationships, n 72, at 36. In 2000, the British Columbia legislature enacted the Definition of Spouse Amendment Act 2000 and brought into force the Definition of Spouse Amendment Act 1999. These Acts did not extend recognition to non-conjugal relationships.

${ }^{87}$ British Columbia Law Institute Report on Recognition of Spousal and Family Status (1999) at 1. This report followed amendments made to the Family Relations Act in 1997, which recognised certain marriage-like relationships.

${ }^{88}$ Ibid, at 24.

${ }^{89}$ Ibid.
} 
consider and report on whether it was desirable to recognise non-traditional relationships. This is perhaps why: ${ }^{90}$

... the report does not set out comprehensive analysis of the pros and cons of this type of reform, the impact it may have on the community, and whether these developments represent a threat to the institution of marriage or to traditional relationships

Without this further analysis it is difficult to assess the merits of the Institute's proposals to determine whether non-conjugal relevant are legally relevant in the areas identified by the Institute. However, the Institute did highlight discrepancies in the approach taken to identifying close family relationships for legal purposes (for example, some legal lists stopped at siblings, others included half-siblings and in-laws), and recommended that a standardised approach be considered.

The Institute recommended enacting a Family Status Recognition Act to define family relationships; set out the rules of general application respecting status, rights, and obligations; and set out rules for determining when such relationships arise and when they end. ${ }^{91}$ The Institute also recommended enacting a Domestic Partner Act to permit two adults to make a joint declaration that they are domestic partners and, as such, have status, rights and obligations similar to those that accrue to people who are married. It was intended that amendments to the statute book would follow to ensure that British Columbia legislation applied fairly to traditional and non-traditional family relationships.

Consistent with this approach, the Domestic Partnership Registry in Nova Scotia allows any two adults to register a domestic partnership. ${ }^{92}$ This is: ${ }^{93}$

... intended to recognize and give certain rights to people in committed, intimate relationships. Penalties may be imposed if individuals attempt to use

\footnotetext{
90 Thomas G Anderson "Comment on the Report of the British Columbia Law Institute on Recognition of Spousal and Family Status" (2000) 12 CJWL 439 at 443 . See also Thomas G Anderson "Models of Registered Partnership and their Rationale: The British Columbia Law Institute's Proposed Domestic Partner Act” (2000) 17 Can J Fam L 89.

${ }^{91}$ British Columbia Law Institute Spousal and Family Status, above n 87, at 30.

${ }^{92}$ Vital Statistics Act, RS, Ch 494, s 2.

${ }^{93}$ Alberta Law Reform Institute Same-Sex Relationships, n 72, at 36.
} 
the DPR to commit fraud to obtain certain benefits to which they would not otherwise be entitled.

The Registry is administered by the Office of Vital Statistics. However, parties can execute a partnership agreement without registering it. If the partnership agreement is executed but not actually registered, the agreement applies between parties but is limited in its application to third parties (though it can help provide evidence of a relationship in the event of intestacy). Upon registration, domestic partners have rights similar to spouses in relation to many different Acts. ${ }^{94}$ Either partner can terminate a partnership by signing a termination of partnership form and notifying the other partner. If the relationship was registered, its termination must also be registered with the Office of Vital Statistics.

\section{$2 \quad$ Application of relationship recognition principles}

Domestic partnerships were introduced in Nova Scotia as a vehicle for recognising same-sex conjugal couples. Similar to the other regimes discussed so far in this chapter, the rights and obligations, therefore, mirror those of marriage. The British Columbia report on which the regime is based can be criticised, because it does not consider the basis for or impact of extending each of these rights and responsibilities to non-conjugal relationships. The rights and obligations in question focus on financial rights and obligations between the parties as well as between the parties and the state. It has been observed of the termination of domestic partnerships that: ${ }^{95}$

\footnotetext{
If your domestic partnership registration included a statement that you and your partner were responsible for each other's living expenses, you'll probably want to immediately notify your ex-partner's creditors in writing that you'll no longer be responsible for his or her bills.
}

\footnotetext{
${ }^{94}$ Vital Statistics Act, RS, Ch 494, s 54(2). These include the Fatal Injuries Act, Health Act, Hospitals Act, Insurance Act, Intestate Succession Act, Maintenance and Custody Act, Matrimonial Property Act, Members' Retiring Allowances Act, Pension Benefits Act, Probate Act, Testators' Family Maintenance Act, Public Service Superannuation Act, Teachers' Pension Act, Wills Act and Workers' Compensation Act. 95 Sherrie Bennett "Domestic Partnership Registration and Benefits" < lawyers.com>.
} 
As the scheme contemplates the registration of same-sex partnerships as well as non-conjugal relationships, there is no data available concerning the specific uptake by those in non-conjugal relationships. Given the experience of other similar regimes, there are likely to be few, if any, relationships registered, because this scheme is also unlikely to reflect the living arrangements or expectations and beliefs of those in non-conjugal partners. Again, questions are raised as to the merits of such a regime with respect to the principles set out in Chapter One.

Unlike the proposals in the British Columbia Law Institute's report, this scheme does not include an ascriptive component, and registration is required to access rights. While ascription may be undesirable in some cases, the Institute did consider rationalising the discrepancies as to how the law defines family relationships (for example, inconsistent inclusion and exclusion of certain family members). However, this element of Institute's report was not adopted.

\section{United States of America}

Like Australia and Canada, relationship recognition in the United States of America is affected by the Constitution and the division of powers between the federal government and states and districts. The federal government does not recognise same-sex marriage in accordance with the Defense of Marriage Act $1996 .{ }^{96}$ However, many of the rights and benefits relating to marriage are determined by the states, not the federal government, and the Defense of Marriage Act does not prevent states from defining marriage in relation to these rights and benefits.

Same-sex marriage has been legalised by courts in three states and in two others and a district through legislation. Prior to this, the federal government had not attempted to define marriage and recognised any marriage recognised by a state, even if other states did not recognise that marriage (for example, interracial marriages before the civil rights movement).

\footnotetext{
${ }^{96} 1$ USC, $\S 7$.
} 
On the whole, America does not provide comprehensive recognition schemes for non-conjugal relationships. However, this section briefly sets out proposals in Hawaii and Vermont to provide registration schemes with very limited legal effect for certain non-conjugal relationships.

\section{A Hawaii \\ $1 \quad$ Reciprocal beneficiary relationships}

Hawaii does not recognise same-sex marriage or civil unions. The Hawaiian Constitution was amended in 1998 to prohibit same-sex marriage and Hawaii's governor recently vetoed legislation that would have established civil unions for same-sex couples. However, Hawaii does recognise reciprocal beneficiary relationships under the Reciprocal Beneficiaries Act 1997. ${ }^{97}$ A reciprocal beneficiary relationship is a legal partnership between two people who are prohibited from marriage and are not currently in another reciprocal beneficiary relationship. ${ }^{98}$ The Act extends certain rights and benefits which were previously available only to married couples to reciprocal beneficiary partners.

Those persons entering into a reciprocal beneficiary relationship must register their relationship as reciprocal beneficiaries with the Hawaiian Department of Health. ${ }^{99}$ Entering a relationship requires the completion of a short declaration form. Parties do not need to demonstrate or affirm that their relationship serves a particular function. Either party may terminate the relationship by filing a declaration of termination of reciprocal beneficiary relationship with the Department. The Department is only responsible for registration and recording and not determinations of validity. Reciprocal beneficiary relationships: ${ }^{100}$

... include but are not limited to relationships such as brother and sister of the half as well as to the whole blood, uncle and nice, aunt and nephew, widowed mother and her unmarried son, and two persons of the same sex/gender.

\footnotetext{
${ }^{97}$ The Reciprocal Beneficiaries Act, HRS.

${ }^{98}$ Ibid, § 572C-2.

${ }^{99}$ Vital records (birth, death, marriage, and divorce certificates) in Hawaii are administered by the Department of Health.

${ }^{100}$ The Reciprocal Beneficiaries Act, HRS, § 572C.
} 
Reciprocal beneficiary relationships are intended to cover both conjugal and non-conjugal relationships. They extend a limited number of the rights and benefits of spouses to reciprocal beneficiaries, including inheritance, workers compensation, property, wrongful death, pensions, hospital visitation and healthcare decision-making. By January 2009, 1,577 reciprocal beneficiary relationships had been registered with the Department of Health. ${ }^{101}$

\section{Application of relationship recognition principles}

The rights and benefits of a reciprocal beneficiaries relationship are more limited than those associated with marriage in Hawaii. The primary purpose of the Act was to provide for the recognition of same-sex relationships rather than non-conjugal relationships. The vehicle for doing so allowed this recognition to take place without acknowledging the conjugal nature of these relationships.

The Act makes it possible for people in reciprocal beneficiary relationships to take domestic leave from work to care for their sick partner and to have hospital visitation rights. Access to these sorts of rights would be beneficial for people in non-conjugal relationships such as the Burden sisters. However, to access them, people would need to register their relationship which may not suit the circumstances of many non-conjugal partners. The Reciprocal Beneficiaries Act is yet another example of a regime set up under the auspices of recognising a wider range of relationships than conjugal relationships, but which is unlikely to meet the needs of these relationships. In the first two years of the Act's operation, it was observed that reciprocal beneficiary relationships had little fiscal impact for the state. ${ }^{102}$

\section{B Vermont}

\section{$1 \quad$ Reciprocal beneficiaries}

Vermont has recognised civil unions between same-sex partners since 2001 and same-sex marriage since 2009 under the Domestic Relations Act. ${ }^{103}$

\footnotetext{
${ }^{101}$ Statistics made available by the Hawaii Department of Health $<$ hawaii.gov/health $>$.

${ }^{102}$ Hawaii State Auditor Study of the Fiscal Impact of Providing Certain Benefits to Reciprocal Beneficiaries R 99-17 (1999).

${ }^{103}$ Vt Stat Ann, title 15.
} 
The Act also allows for the recognition of "reciprocal beneficiaries relationships", a legislative scheme that was introduced at the same time as civil unions. $^{104}$ The purpose is to: ${ }^{105}$

... provide two persons who are blood-relatives or related by adoption the opportunity to establish a consensual reciprocal beneficiaries relationship so they may receive the benefits and protections and be subject to the responsibilities that are granted to spouses.

These benefits only relate to a limited number of areas specified in the Act. These are: hospital visitation and medical decision-making; decisionmaking relating to anatomical gifts; decision-making relating to the disposition of remains; advance directions (meaning a power of attorney for health care and terminal care documents); patient's bill of rights (allowing a reciprocal beneficiary partner to receive information relating to the patient); nursing home patient's bill of rights; and abuse prevention.

Two persons who meet the criteria in $\S 1303$ may establish a reciprocal beneficiaries relationship by presenting a signed, notarised declaration of a reciprocal beneficiaries relationship to the Commissioner for Health and paying a filing fee. Either party to a reciprocal beneficiaries relationship may terminate the relationship by filing a signed, notarised declaration with the Commissioner. If a party to a reciprocal beneficiaries relationship enters into a civil union or marriage, the reciprocal beneficiaries relationship terminates.

In 2000, the Vermont Civil Union Review Commission was established by law to review the effectiveness of the new legislation in its first two years of operation. In addition to a review of civil unions entered into, the Commission was also tasked to: ${ }^{106}$

\footnotetext{
Examine reciprocal beneficiaries relationships and evaluate whether nonrelated persons over 62 years of age should be permitted to establish a reciprocal beneficiaries relationship, and whether the legal benefits, protections and responsibilities of a reciprocal beneficiaries relationship should be expanded.
}

\footnotetext{
${ }^{104}$ Vt Stat Ann, title 15.

${ }^{105}$ Vt Stat Ann, title 15, $\$ 1301(\mathrm{a})$.

${ }^{106}$ Vt Stat Ann, title 15.
} 
No reciprocal beneficiaries relationships were registered while the Commission undertook its two reviews. In its first review, the Commission did not comment on whether further rights and benefits should be extended to such relationships or whether elderly non-relatives should be able to enter into a reciprocal beneficiaries relationship. ${ }^{107}$ This is most likely because the primary purpose for establishing the Commission was to consider the impact of the new civil union provisions of the legislation.

However, this matter was briefly dealt with in the second and final report of the Commission. ${ }^{108}$ The Commission called for submission from certain age-care concern interests groups. However, these groups did not make an appearance. Despite the fact that no such relationships had been registered, the Commission indicated that the state Department of Personnel had submitted that: $^{109}$

Unlike a party to a civil union, a person entering a reciprocal beneficiaries relationship is primarily doing so to obtain legal benefits. A person may enter a reciprocal beneficiaries relationship solely to obtain insurance benefits for an elderly or ill relative, and that could make insurance more expensive for everyone. If benefits were extended to reciprocal beneficiaries, insurers would expect to get a disproportionate number of persons who are a "bad risk", requiring significant repricing.

Prior to the introduction of legislation allowing same-sex marriage, the Vermont legislature considered the Reciprocal Benefits Bill (never enacted) that would have disestablished civil unions and reciprocal beneficiaries relationships and replaced them with reciprocal partnerships. $\$ 1301$ of the Bill provided that to enter into a reciprocal partnership a person must be at least 18 years of age; not in a marriage or in another reciprocal partnership; be ineligible to marry; be competent to enter a contract; and consent to the reciprocal partnership without force, fraud or duress. Clause $\S 1224($ a) provided that:

\footnotetext{
107 Vermont Civil Union Review Commission Report of the Vermont Civil Union Review Commission (2001).

${ }^{108}$ Vermont Civil Union Review Commission Report of the Vermont Civil Union Review Commission (2002).

${ }^{109}$ Ibid, at 14 .
} 
A reciprocal partner shall have all the same benefits, protections and responsibilities under law, whether they derive from statute, administrative or court rule, policy, common law or any other source of civil law, as are granted to a spouse in a marriage.

\section{Application of the relationship recognition principles}

Bala condemns reciprocal beneficiaries relationships on the basis that: ${ }^{10}$

For the same political reasons that motivated the Alberta government, the Vermont legislature also created the "reciprocal beneficiary relationship" to allow two persons related by blood or adoption to register and gain a limited legal relational status with each other. While almost 3,500 civil unions were entered into by the beginning of 2002, there was not a single reciprocal beneficiary relationship registered. Neither in Vermont nor anywhere else in the world are adults who are residing together in non-conjugal relationships involving economic interdependence and emotional ties seeking a "legal status" remotely akin" to "spousal". In particular, there seems to be no interest or expectation that there should be any oblibtaions, such as support claims, extending beyond the termination of cohabitation.

This observation might be pertinent if made in respect of the proposed reciprocal partnerships under the Reciprocal Benefits Bill. However, this Bill was not passed and reciprocal beneficiaries relationships do not have the legal consequences suggested by Bala, as they only extend a limited number of the rights and obligations of spouses. In fact, these are areas of law where New Zealand also tends to recognise non-conjugal relationships (such as domestic violence, hospital visitation, powers of attorney and medical decision-making). The state has an interest in allowing certain close personal relationships some rights in respect of these areas.

At first glance, the reciprocal beneficiaries relationships scheme might be considered to promote the principles of relationship recognition (depending on whether the fact the scheme does not involve all the rights and benefits of marriage was considered to undermine equality or not). However, on the whole, the scheme does not appear effective in achieving its limited policy objectives.

${ }^{110}$ Nicholas Bala “Adult Interdependent Relationships”, above n 66, at 97 to 98. 
For example, the scheme allows reciprocal beneficiaries partners to be considered "family" for the purposes of domestic violence laws. The approach in New Zealand, however, is that a person should not need to register to come within the protection of these laws. Likewise, the reciprocal beneficiaries scheme allows partners to enter into a power of attorney arrangement before a notary public. In New Zealand, powers of attorney are not limited to certain relationships, but can be chosen without restriction, provided that criteria such as receiving independent legal advice are met.

In addition, limiting such schemes to relatives by blood or adoption, where most close family relationships (such as siblings) could reasonably be recognised in these instances, is odd. Ultimately, the scheme does not provide an effective basis for offering legal protections in certain areas to an appropriate range of non-conjugal relationships. The Commissioner of Health keeps a record of all reciprocal beneficiaries. However, correspondence with the Vermont Department of Health reveals that no reciprocal beneficiaries partnerships have been registered with the Department of Health to date. ${ }^{11}$ Ultimately, the Commission, in undertaking its review, concluded that: ${ }^{112}$

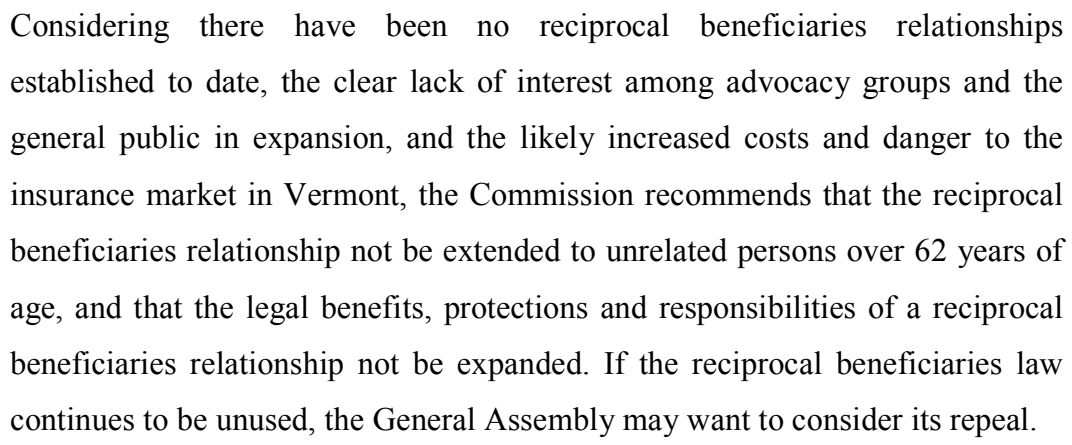

\section{$V \quad$ Other Overseas Examples of the Recognition of Non- Conjugal Relationships}

This chapter has identified and described the major schemes introduced in overseas countries for recognising non-conjugal relationships in a manner

\footnotetext{
${ }^{111}$ Email from Linda Merchant (Vital Records Supervisor, Vermont Department of Health) to Lorraine Johns regarding number of reciprocal beneficiaries relationships registered with the department (24 August 2010).

${ }^{112}$ Vermont Civil Union Review Commission Report (2002), above n 108, at 14.
} 
similar to marriage. It has not attempted to identify all instances of recognition for particular purposes as these would be numerous and this task is unnecessary to achieve the aims of this thesis. However, there are two other examples of recognition of non-conjugal relationships that occur overseas that are set out briefly here.

First, the legal concept of "common household" in Portugal is of interest. Portugal has recognized de facto unions between same-sex couples since 2001 and same-sex marriage since 5 June 2010. Portugal introduced civil unions for opposite-sex couples in 1999 and for same-sex couples in March $2001{ }^{113}$ The law covers matters such as housing, work and welfare benefits for both same and opposite-sex de facto couples. There is no registration process and the regime applies after a couple lives together for two years. Essentially the law sets up an ascription regime. However, an application for a joint tax assessment can be made to prove the existence of the relationship (though this is not required).

Also on 15 March 2001, a law known as "common economy" was also approved that extended to two or more persons who live in common economy, most of the rights of those in de facto relationships, except for welfare benefits. No other information is readily available about these schemes. However, Santos writes that: ${ }^{114}$

... while there is nothing that prevents a homosexual couple from benefiting from the legal protection provided by the law on common economies, this was considered insufficient by Portuguese LGBT associations, since it removes the affective component from the LGBT family relationship, reducing it to a merely economic concern.

The Netherlands has also passed legislation establishing a scheme that may apply to those in non-conjugal relationships. The Netherlands has a reputation has one of the most progressive countries in the world in areas of

\footnotetext{
113 Adopta Medidas de Protecção das Uniões de Facto 2001

${ }^{114}$ Ana Cristina Santos "Sexual Orientation In Portugal: Towards Emancipation" (2004) 9 South Euro Science \& Pol 159 at 161.
} 
social reform. Same-sex marriage became available in the Netherlands from 1 April 2001. The Dutch Ministry of Justice has stated that: ${ }^{15}$

The principle of equal treatment was decisive. For many people, marriage is a symbol that carries a special meaning. They see it as a way of confirming their commitment to each other. There is no reason why same-sex couples should be denied the opportunity to do so.

In addition to marriage and de facto relationships, Dutch law provides for registered partnerships and cohabitation agreements. ${ }^{116}$ All four living arrangements are open to same or opposite-sex people. Registered partnerships are based on a conjugal model but cohabitation agreements are not. Registered partnerships are not open to more than two people, whereas cohabitation agreements are. Each serves a different purpose.

A cohabitation agreement is a contract between two people or more people. $^{117}$ It covers a variety of matters relevant to living together and sharing a home. Participants can make their own arrangements or seek the assistance of a notary to draft an official cohabitation agreement. An official agreement is needed to be eligible for matters such as partner's pension schemes and certain other benefits, and creates rights which can be enforced against the state. A cohabitation contract sets out the rights and obligations that a couple chooses for themselves. It does not have implications for private third parties.

In 2005 this regime was subjected to some worldwide controversy, when it was reported that the Netherlands had commenced recognising plural marriages after three people entered into a cohabitation contract and undertook a ceremony resembling a marriage ceremony. ${ }^{118}$ Arguably, this approaches raises some public policy issues, if the state does not wish to appear to recognise polygamous households. In particular, while a regime may be intended to recognise non-conjugal relationships, if the regime is similar in other respects to marriage, then there is a risk that, in practice, it could be used to register

\footnotetext{
115 The Netherlands Ministry of Justice "Same-Sex Marriages" <english.justitie.nl>.

116 Access Marriage, Registered Partnership, Cohabitation and Ending a Relationship (Netherlands, 2010) at 2.

117 Ibid.

${ }^{118}$ Stanley Kurtz "Here Comes the Brides: Plural marriage is waiting in the wings" The Weekly Standard (26 December 2005).
} 
polygamous relationships. The then Dutch Minister of Justice refused to repeal the law relating cohabitation agreements when this matter received publicity, stating that "contracts that settle the cohabitation of more than two persons can have a useful ordering function."119

\section{Conclusion}

The overseas regimes set out in this chapter represent efforts to extend some or many of the rights and obligations of marriage to non-conjugal relationships. Some of these regimes make no distinction between conjugal and non-conjugal relationships, while others have separate categories for each. The schemes have many factors in common. First, they all occur in the midst of debate about same-sex and de facto relationship reform, and it has been suggested that they were driven by a desire to recognise non-traditional conjugal relationships without having to acknowledge their conjugal nature.

Second, they are modelled on conjugality. Where relationship status is ascribed, the factors for identifying relationships are similar or identical to those traditionally associated with identifying a conjugal relationship. In some cases, factors even include children and the presence of a sexual relationship. These two factors have been removed in some models, but the other remaining factors are similar to the criteria in New Zealand that are intended to assist with identifying whether people are living together as a couple.

These schemes all raise issues with respect to the principles of relationship recognition identified in Chapter One. It is unlikely that they promote equality because it is not clear that non-conjugal relationships should be treated the same as conjugal relationships, as there are arguably material differences between the two. This concern is reflected in, for example, Alberta's decision not to extend an ascription regime to relatives, although such a regime was extended to non-relatives. This was because of concerns that legal obligations might arise that could not reasonably be expected. Comprehensive

${ }^{119}$ Paul Belien "Dutch Minister Not To Prevent Polygamy" The Brussells Journal (1 November 2005). 
ascription regimes, in particular, may infringe upon the autonomy of those in non-conjugal relationships.

There is also a concern about whether these regimes give effect to the principles of effectiveness, coherence and certainty. The relationships to which they apply are not entirely clear. The low uptake of these schemes by nonconjugal partners - possibly no non-conjugal relationships have been registered under any of these regimes - does not promote respect for the law. The criteria in the registration regimes (for example, that a relationship be committed or caring) would be difficult to enforce and undermine the registration approach, which traditionally allows people to self-select which of their relationships should be legally relevant by using procedural, rather than substantive criteria.

Ultimately these schemes raise more questions than they answer about the recognition of non-conjugal relationships. The practical need for and effect of the majority of these schemes is unclear and the reliance of legislatures on principles such as equality to justify these schemes appears misguided. What this suggests is that it is not so much a case of extending conjugal regimes to include non-conjugal relationships, as recognising non-conjugal relationships in their own right. 


\section{CHAPTER FIVE: RECOGNISING NON-CONJUGAL RELATIONSHIPS IN NEW ZEALAND}

\section{Introduction}

This thesis has argued that non-conjugal relationships have important benefits for society and can perform many of the same functions as conjugal relationships. The state depends on both conjugal and non-conjugal relationships to ensure that individuals are provided with emotional and economic support as this, in turn, supports social cohesion. The question is whether non-conjugal relationships should be recognised in the same way as marital and marriage-liked relationships in New Zealand, or whether there are better ways for the law to recognise them.

It is outside the scope of this thesis to undertake a comprehensive survey of all the rights and obligations attaching to marital and marriage-like relationships, and to assess whether these should apply to certain non-conjugal relationships. This is not required, however, to come to the conclusion that the marriage model does not appear to recognise the needs of or relate to living arrangements in most, if not all, non-conjugal relationships. This chapter sets out some of the reasons against applying marriage-like ascription and registration schemes to non-conjugal relationships and what further analysis would be required if this was to occur in New Zealand.

Ultimately, there are better ways of addressing concerns about the equality of people in non-conjugal relationships than allowing them to register their relationship so that it is treated in the same way as a marriage or civil union. This chapter proposes a framework for recognising personal relationships in New Zealand and applies it to areas of New Zealand law where non-conjugal relationships might receive better legal recognition. The development and maintenance of non-conjugal relationships can be enhanced by carefully crafted legislation that recognises these relationships in their own right, rather than as analogous to marriage or marriage-like relationships. In fact, whether a relationship is conjugal or not may be irrelevant to achieving the policy objective of a particular law. 


\section{The Disadvantages of Extending the Marriage Model}

In a 2010 lecture, Baroness Deech of Cumnor queried: ${ }^{1}$

... why in English law we treat siblings less favourably than married or civil partners; and why we do not expect adults to maintain their parents or their grandparents in return for the keep that was extended to them in their youth. One has to wonder why ... the blood relationship comes second.

The argument for treating conjugal and non-conjugal relationships as analogous rests on assumptions that there are no material differences between these types of relationships and that people in non-conjugal relationships face the same legal problems as those in conjugal relationships. This assumption was questioned in Chapter Two, but there are other reasons for not adopting the approach taken overseas in recognising non-conjugal relationships by extending the marriage model to include such relationships.

The key disadvantages of extending the marriage model to non-conjugal relationships in New Zealand are set out below. In particular, this could defeat the reasonable expectations of those in non-conjugal relationships (thereby discouraging their formation); it does not appear to take into account the specific needs of people in non-conjugal relationships or reflect the nature of the living arrangements of people in these relationships; it may entail costs to the state which need to be quantified and assessed; it may impact on equality between conjugal relationships; and it may appear to legitimise polygamous or incestuous relationships.

This does not mean that non-conjugal relationships should not receive any legal recognition or that such relationships do not face any legal problems. Rather, there are two ways of improving legal recognition of non-conjugal relationships so that they are better supported by the state. First, partial or comprehensive registration and ascription regimes could be introduced, provided that they are based on a sound understanding of the needs and living arrangements of people in the non-conjugal relationships to which they apply.

\footnotetext{
${ }^{1}$ Baroness Deech of Cumnor "Sisters, sisters, there were never such devoted sisters" (Gresham College, 2 February 2010).
} 
Specific law reform projects would be required to achieve this. Second, rights and responsibilities could be accorded to these relationships on a case-by-case basis, as new laws are developed and current laws reviewed. This exercise should be guided by an overarching framework for recognising personal relationships, based on the principles identified in Chapter One.

\section{A Defeating the Expectations of Non-Conjugal Relationships}

This thesis has acknowledged that it is becoming more difficult to conceptualise and articulate material differences between conjugal and close non-conjugal relationships, in terms of features that are relevant to legal rights and responsibilities. However, conjugal relationships, ideally, are associated with a greater degree of interdependency, commitment and sharing of lives. Therefore, while both conjugal and close non-conjugal relationships may exhibit similar features, there may be a material, qualitative difference in the manner and extent to which these features are exhibited. In any event, it is clear that conjugality is not simply a matter of "household economies" as suggested by the Law Commission of Canada in Beyond Conjugality. ${ }^{2}$ Bala states that conjugality is not exclusively defined in sexual terms and that: ${ }^{3}$

What distinguishes a conjugal cohabiting relationship from two roommates living together, or from an adult child and parent residing together, is the combination of their interdependent roles and the expectations about the relationship. While individual attitudes and behaviours vary, Canadians still generally have a profoundly important set of cultural, psychological and spiritual feelings about conjugal relationships.

The low uptake of schemes set out in Chapter Four indicates that most people in non-conjugal relationships do not perceive their relationship as analogous to marriage or a marriage-like relationship. This is most likely because the marriage model does not reflect expectations about the degree to which the lives of those in non-conjugal relationships will be shared as well as expectations about their living arrangements. We must look beyond the immediate consequences of an inheritance tax bill in making this assessment.

${ }^{2}$ Law Commission of Canada Beyond Conjugality: Recognizing and supporting close personal adult relationships (2001) at 29.

${ }^{3}$ Nicholas Bala and Rebecca Jaremko Bromwich "Context and Inclusivity in Canada's Evolving Definition of the Family" (2002) 16 IJLPF 145 at 171. 
This raises the concern that, for the purposes of comprehensive legal regulation, it may not appropriate to recognise conjugal and non-conjugal relationships in the same way and for the same purposes. The principles of relationship recognition identified in Chapter One support the legal recognition of non-conjugal relationships, but only to the extent that this supports and promotes these relationships.

The general extension of the legal consequences of marital relationships to non-conjugal relationships by ascription would defeat the reasonable expectations of most, if not all, people living in these relationships. In Alberta, family relationships were excluded from having adult interdependent relationship status conferred on them by ascription for this reason. Some marital rights and obligations are premised on the idea of shared lives, exclusive commitment and how to restore order when the relationship breaks down. It does not seem equitable or appropriate to extend these particular rights and obligations to most non-conjugal relationships.

In addition, the dependency present in conjugal relationships may differ from that in non-conjugal relationships. Bala observes that: ${ }^{4}$

... despite individual variations, there is an expectation between spouses that both will gain from the relationship and that they will share at least some significant aspects of their economic lives. This can be contrasted with the situation of adult children living at home with their parents. The relationship is one of dependence, where the adult child depends on their parents to share common resources, for example, so the child can undertake tertiary study.

In the case of an adult child living with his or her parents, in New Zealand, guardianship of a child and, thereby, any financial responsibility, ends at age $18 .^{5}$ It would be inconsistent with this to suggest that financial responsibility for a child might continue simply because an adult child remains financially dependent on his or her parents after the child turns 18 .

\footnotetext{
${ }^{4}$ Nicholas Bala "Controversy over Couples in Canada: The Evolution of Marriage and Other Adult Interdependent Relationships" (2003-2004) 29 Queens LJ 41 at 43.

${ }^{5}$ Care of Children Act 2004, s 8.
} 
Bala suggests that many non-conjugal relationships are actually relationships of dependence, rather than interdependence, whereby one party is primarily dependent on the other for financial resources. ${ }^{6}$ He suggests that it is atypical for major property to be shared, and when it is, there are generally clear contractual responsibilities (as is likely where two friends or sisters buy a first house together in order to make owning property more affordable in the absence of a conjugal partner). It may be appropriate to draw a distinction in law between non-conjugal relationships that are dependent and those that are independent for the purposes of legal recognition. For example, dependency might be relevant to a claim for a death benefit but not for "termination" of a relationship (for instance, where the adult child leaves home). Even where it is relevant, it may be that the common law rules of equity are better able to address issues that arise than the statutory regime and assumptions of the Property (Relationships) Act 1976.

Bala and Jaremko Bromwich also raise a concern about whether imposing obligations on non-conjugal partners might damage some of these relationships. ${ }^{7}$ They highlight the plight of dependent adults, such as the elderly, who may have a "limited pool of friends or family willing to allow the dependent person to share a residence and provide support." the supportive adult might face a difficult decision about whether to continue to support the dependent adult, if there are legal burdens added to those practical ones they already face in undertaking such care. Bala and Jaremko Bromwich consider this is likely to: ${ }^{9}$

... have a very significant adverse impact on how many dependent adults receive care from relatives or friends. Because of the different ties in a conjugal relationship, the imposition of obligations would have a greater disincentive on the formation of non-conjugal households than for conjugal households.

Bala and Jaremko Bromwich also observe that conjugality is still linked with children and that there are few who would consider raising a child with a non-conjugal partner. They consider that the "commitment of the adults to their

\footnotetext{
${ }^{6}$ Nicholas Bala "Controversy over Couples" above n 4, at 43.

${ }^{7}$ Bala and Jaremko Bromwich "Context and Inclusivity", above n 3, at 171.

${ }^{8}$ Ibid.

${ }^{9}$ Ibid.
} 
relationship that is inherent in conjugality is also desirable in establishing an environment in which to raise children."

The concerns raised above relate primarily to the extension of an ascription-based regime to non-conjugal relationships, as registration of such relationships would only take place by consent. However, as discussed now, there is also a concern as to whether the expansion of marriage-like registration regimes would meet the needs of those in non-conjugal relationships or whether registration should even be required to access the legal recognition required by those in non-conjugal relationships.

\section{B Meeting the Specific Needs of those in Non-Conjugal Relationships}

In New Zealand, in 2005, de facto relationships became subject to almost all of the same rights and obligations as married couples due to the passage of the Relationships (Statutory References) Act 2005. This Act was informed by comprehensive analysis undertaken by the New Zealand Ministry of Justice as to whether it was appropriate to extend the rights of married couples to de facto relationships and the advantages and disadvantages of doing so. Cross, Palmer and Smith suggest that: ${ }^{11}$

\footnotetext{
... individuals in kinship groups may not want the full range of rights and duties accorded in domestic partnership or marriage laws. Thus, kinship arrangements can range from "offering the most extensive rights and obligations" that can be offered in adult relationships to "no rights or obligations at all" between adults. Between these two extremes lies the concept of the granting of benefits and entitlements that are important to share in emotionally and economically interdependent relationships.
}

The marriage model does not appear to suit the living arrangements of people in non-conjugal relationships. This may be for a variety of reasons. For example, while some of the legal consequences may be desired by parties (such as protection from domestic violence or hospital visitation rights), others may not (such as being treated as a couple where one person is in receipt of a benefit or the division of assets that might result if the relationship ends due, for

\footnotetext{
${ }^{10}$ Ibid, at 172.

11 Jane E Cross, Nan Palmer and Charlene L Smith "Families Redefined: Kinship Groups That Deserve Benefits” (2008-2009) 78 Miss LJ 791 at 827.
} 
example, to one of the parties deciding to marry, although this does not affect the parties' friendship).

It was also suggested in Chapter Three that registration schemes (and, in particular, marriage) have a significant symbolic function. It is likely that people in non-conjugal relationships do not require this symbolic recognition. In fact, many may shy away from a formal registration process which would have the same symbolic connotations as entering into a marriage or marriagelike relationship. Many may wish to marry in the future.

Another matter that is rarely considered in the literature is the design of the procedural requirements for entering into and dissolving a registered nonconjugal relationship. In some cases, a registered relationship is terminated by a unilateral declaration by one party or the act of entering into a marriage. In others, a period of time may be imposed before the relationship is terminated. This, again, may not reflect the way in which people form and end close nonconjugal relationships.

In fact, non-conjugal relationships may not "terminate" in the same manner as conjugal relationships at all. When a conjugal relationship terminates, this represents a decision that the other party no longer exclusively values the other or wishes to maintain a shared life or commitment to a shared future. While the New Zealand family law system is set up to encourage reconciliation where possible, the reality is that where conjugal partners separate, the nature of their relationship fundamentally changes and it is likely that both will want to repartner at some point in the future.

However, where people are living together in non-conjugal relationship, "termination" may be for different reasons and the relationship may not change in its importance or break down. In particular, it is desirable for adult siblings and parents, as well as other family members, to maintain an ongoing relationship. The "clean break" principle does not apply to these relationships. While there may be an expectation of repartnering for a conjugal couple, this is not the same for non-conjugal partners, particularly where they are family 
members related by blood. The family relationship persists despite any differences between the individuals.

Moreover, a registered partnership between family members may confuse or distort an existing social and legal relationship. It is also possible to be in an important non-conjugal relationship at the same time as a conjugal relationship. For example, an elderly widow living with an adult child and the adult child's spouse, until the widow passes away. It is common for family or extended family members to live together in Pacific Island and Māori families in New Zealand. This does not mean that these relationships should be subjected to the legal consequences of conjugality. Any recognition regime should take note of and manage these factors as well as any cultural differences.

A key area of concern that has been raised with respect to the recognition of non-conjugal relationships as marital relationships is ensuring that property rights can be adjusted should relationships break down. This is particularly so because the close nature of such relationships means that parties might not make use of private contract to sort such issues before they arise (and these issues might also arise by virtue of the relationship following purchase of the property). However, equity uses constructive trust to deal with such situations where they arise, as in the cases of Riddle $v$ Jones and Tickner $v$ Wheeler. $^{12}$ This approach allows the court to take equitable interests into account where parties have not contracted to deal with the division of property in which both might have an interest.

As indicated, a comprehensive survey of the law is outside the scope of this thesis. However, it appears that people in non-conjugal relationships face their own legal issues that may require different legal solutions. Ultimately, registration is not required for the extension of legal protections as demonstrated by the comprehensive model New Zealand has in place for recognising de facto relationships. Analysis of the specific implications of extending the various rights and duties associated with marriage would be required before any

\footnotetext{
${ }^{12}$ Riddles $v$ Jones (High Court, Nelson, CP 39/88, 20 June 1990); Tickner $v$ Wheeler (1985) 3 NZFLR 782 (both involving a mother and daughter).
} 
extension in New Zealand should be proposed, either on the basis of ascription or registration.

Finally, the state must consider (in establishing a non-conjugal registration scheme) the effect that uptake of this scheme might have on conjugal relationships, particularly if a non-conjugal relationship could not be registered at the same time as a conjugal relationship. Fineman suggests that: ${ }^{13}$

Some people continue to insist that legitimate families can only be built upon the foundation of a traditional marital tie. Others emphasize the biological connection and minimize the importance of legal relations in favor of kinship structures that form affiliations transcending current formal definitions of the family. For others, the preference is for an affectional family, a unit composed of those with whom we choose to connect but who may not be "related" to us by either blood or marriage

Nonetheless, the state has an ideological and cultural interest in the institution of marriage and any policies that might have an impact on conjugality or children of those relationships. This does not mean that ideological and cultural values should outweigh any other principles supporting the recognition of non-conjugal relationships, but they are factors that should be considered. The state should also take into account any impact on the formation of non-conjugal relationships. Arguably, the nature of family is such that support may be provided by one family member (or a friend) to another without the creation of obligations between parties. It is likely that non-conjugal partners seek rights in relation to the state and third parties rather than in relation to each other. On balance, the marriage model does not seem suitable for non-conjugal relationships. People in non-conjugal relationships, are not always, as suggested by Welstead "analogous counterparts of spouses and civil partners." 14

\footnotetext{
13 Martha Fineman "Masking dependency: the political role of family rhetoric (Symposium: New Directions in Family Law)" (1995) 81 Va L Rev 2181 at 2190.

${ }^{14}$ Mary Welstead "England and Wales: The Family the Law Forgot" in Bill Atkin (ed) The International Survey of Family Law 2010 Edition (Jordans, Bristol, 2010) 113 at 119.
} 


\section{The Cost of Legal Recognition}

During debate in House of Lords on the Civil Partnership Bill 2004 (UK), a concern was raised about the financial implications of extending the Bill to include non-conjugal relationships in terms of the impact on the payment of pension rights to non-spouses. A concern was also raised in respect of the Burden sisters' case before the European Court of Human Rights, that allowing a further exception to the payment of inheritance tax would substantially reduce the government's revenue. This indicates that care should be taken to quantify any costs of creating a registration regime for non-conjugal partners, both for the state and third parties. The state's resources are necessarily limited and governments must prioritise the allocation of scare resources. Third parties may also be affected by any required changes, such as in employment leave policies or insurance policies.

This does not mean that human rights and other considerations could not outweigh the fiscal impact of extending state support or requiring third parties to recognise a wider range of personal relationships. However, fiscal implications should be considered during the development of any comprehensive registration or ascription scheme.

\section{Impact on Equality between Conjugal Relationships}

The relationship recognition principles outlined at the start of this thesis identified equality as a principle that should be given priority by any relationship recognition regime introduced in New Zealand. This does not just refer to equality between conjugal and non-conjugal relationships. It also refers to equality between conjugal relationships. This principle does not require all personal relationships to be treated in the same way. Only like relationships should be treated similarly. Same-sex and de facto relationships have a long history of being stigmatised and some consider that these relationships cannot be equated to heterosexual marriage on religious, moral or philosophical grounds. Bala and Jaremko Bromwich point out that: ${ }^{15}$

\footnotetext{
${ }^{15}$ Bala and Jaremko Bromwich "Context and Inclusivity", above n 3, at 172.
} 
... for some politicians the project of abandoning conjugality may be a way to make legal recognition of same-sex relationships less politically contentious. The de-emphasis on conjugality may be seen as a way of subverting conservative opposition to legal recognition of partnerships outside marriage. But it is also way of hiding same-sex relationships.

The recognition of non-conjugal relationships should not be used as a vehicle to recognise non-traditional conjugal relationships, in order to conceal the conjugal nature of these relationships. New Zealand recognised that these relationships deserve state support and protection in passing the Civil Union Act in 2004 and Relationships (Statutory References) Act 2005. Therefore the same concern does not arise in New Zealand, except to the extent that New Zealand does not allow same-sex marriage.

The recognition of non-conjugal relationships does not appear to have been formally considered during the development of the Civil Union and Relationships (Statutory References) Bills. However, at the time the civil union legislation was passed, it was argued that civil union registration should be applied to 'non-romantic relationships'. While the Departmental Reports of the Ministry of Justice on the Civil Union and Relationships (Statutory References) Bills do not refer to the recognition of non-conjugal relationships, the Maxim Institute, a well-known conservative lobby group in New Zealand, considered at the time that: ${ }^{16}$

The Civil Union Act discriminates against people in committed but nonromantic relationships who want the legal certainty of registration but not the marriage-like ceremony of a civil union ... the Maxim Institute firmly believes that clarity around next-of-kin status is important for all people, not just romantic relationships ... there is a need for an opt-in relationship which has clear legal rights but does not mimic marriage as the civil union does, because this is inappropriate for many people.

\section{E Concerns about Polygamous or Incestuous Relationships}

There is also a concern that if non-conjugal relationships can be legally registered, then it will be possible for people to register polygamous or

\footnotetext{
${ }^{16}$ Garth George "Civil union fuss turns about much ado about nothing” New Zealand Herald (4 May 2006).
} 
incestuous relationships. In New Zealand, it is not possible to register either of these relationships. Polygamous marriages are prohibited under the Marriage Act 1955, although s 2 of the Family Proceedings Act 1980 permits the recognition of overseas polygamous marriages. The United Nations Human Rights Committee has stated that "Polygamy violates the dignity of women. It is an inadmissible discrimination against women. Consequently, it should definitely be abolished wherever it continues to exist."17 Incestuous relationships may have criminal consequences.

If a registration scheme were introduced for non-conjugal relationships, it would be necessarily to consider whether it was appropriate to allow more than two people to register such a relationship. On the one hand, non-conjugal relationships may genuinely involve more than two people (for example, consider the scenario if the Burden sisters had also had a third sister). On the other, the state should not undertake measures that could promote polygamous unions, unless there are other important objectives (such as the support and protection of children). In the Netherlands, as discussed in the previous chapter, concerns have been raised about whether cohabitation agreements legitimise polygamous relationships.

Likewise, concerns were raised in the United Kingdom during the debate on the proposed amendment to the Civil Partnerships Bill (extending the Bill to cover long-term cohabiting siblings), as to whether this would amount to an endorsement of incestuous relationships. Registration schemes are typically crafted to exclude relationships within the prohibited degrees of consanguinity or affinity. This is reflected in both the Marriage Act 1955 and the Civil Union Act 2004 in New Zealand. While it is unlikely that many, if any, incestuous relationships would be registered, there are documented cases of incestuous relationships occurring, including where children are born of these relationships. The state should take care in developing any registration scheme that could, conceptually, allow for legal recognition of such relationships. However, none of the relationship recognition schemes outlined in Chapter Four prohibit the registration of an incestuous relationship.

${ }^{17}$ United Nations Human Rights Committee General Comment No 28, Equality of rights between men and women (Article 3) CCPR (29 March 2000). 


\section{F The Plight of the Burden Sisters: Responses other than Comprehensive Recognition Based on the Marriage Model}

A comprehensive registration or ascription regime is not necessarily required to address the concern raised by the Burden sisters regarding the payment of inheritance tax. It is not completely clear whether the Burden sisters were seeking that their relationship be recognised as a civil partnership, if this were required to gain an exemption from in heritance tax, though this was suggested in the parties' arguments. The essence of their case was, however, that, for the purposes of inheritance tax, it was unjust to treat their relationship differently from civil partnerships or marriage.

As noted in Chapter Three, estate duty, the New Zealand equivalent of inheritance tax, was abolished by the Estate Duty Abolition Act 1993. Abolishing inheritance tax would also be one option for addressing the Burden sisters' concerns. This was not considered in the European Court of Human Rights due to acceptance by both parties of the legitimacy of the policy and the legitimacy of the exemption for married couples. ${ }^{18}$ However, this approach does not involve discriminating between different personal relationships.

In New Zealand, the abolition of gift duty has also been proposed. It has been suggested that this will have little fiscal impact due to a practice whereby people gift assets away to a trust over a long period of time in order to avoid gift duty. ${ }^{19}$ As such, another option for the Burden sisters would have been to explore whether careful estate planning could mitigate the consequences of inheritance tax on the death of one of the sisters, by gifting assets to a trust over a long period of time. The specific statutory regime in place would also have allowed the surviving sister to pay a portion of the inheritance tax each year over a period of many years.

However, arguably the sisters should not need to employ careful accounting strategies in order to avoid the inheritance burden placed on the surviving sister. It was suggested by the majority judges in both divisions of the European Court of Human Rights that the Burden sisters do not deserve an

\footnotetext{
${ }^{18}$ Kenneth McK Norrie "Inheritance tax, civil parntership and the rights of spinster sisters" (2008) 12 Edinburgh LR 1364.

${ }^{19}$ Hon Peter Dunne “Government Signals Repeal of Gift Duty” (press release, 14 June 2010).
} 
exemption from inheritance tax because they have not taken on any of the obligations of civil partners. However, it is not clear what obligations are contemplated, and, if they are support obligations, it likely that the non-conjugal relationship between the Burden sisters has produced savings for the state in terms of the care provided by each of the sisters by the other. In other words, a connection between benefits and obligations should be drawn before deciding that, in order to gain a particular legal right, people must consent to certain obligations.

There is, however, a solution that would not require the state to yield any of the income that it received from inheritance tax and at the same time, would ensure that the surviving sister would not have to sell the family home to pay an inheritance tax bill. This solution would be to defer inheritance tax liability on the death of the first sister until the death of the second sister. Payment would be secured by a charge on the sisters' properties, with interest calculated at an appropriate rate and paid in full on the death of the second sister (at this time, the full amount of inheritance tax would be paid in respect to each sister). This deferred payment, particularly if only applicable to long-term cohabitants, would have few fiscal implications for the state. It has been observed that: ${ }^{20}$

\footnotetext{
The Burdens' situation may seem heart-rending. But, with a little careful planning, it is still possible for people like them to save a fortune in IHT and even get to leave the family home to their loved ones.
}

No doubt an inequitable situation existed between that of the very longterm cohabiting Burden sisters and married couples and civil partners. However, this does not automatically provide a basis for applying the marriage model to all non-conjugal relationships.

\section{G Conclusions as to the Merits of Extending the Marriage Model to Include Non-Conjugal Relationships}

This thesis concludes against extending the rights and obligations of marriage to people in non-conjugal relationships in New Zealand, either by registration or by ascription. This is not because these relationships do not

\footnotetext{
${ }^{20}$ Kate Hughes "Protect your family from the taxman" The Independent (United Kingdom, 4 May 2008).
} 
deserve legal recognition, but rather, because it does not appear that they require recognition in the same way as marriages or marriage-like relationships. While there are similarities between conjugal and non-conjugal relationships, it is possible, in most cases, to distinguish between the two.

This does not necessarily result in the privileging of marriage and marriage-like relationships over other caring relationships. It is possible to recognise both at the same time. However, people in non-conjugal relationships are generally likely to have different expectations of their living arrangements than those in conjugal relationships. The law should give effect to these expectations rather than simply extend the rules relating to conjugal relationships because this is a mechanically simple. There are compelling arguments against extending an ascription-based model to non-conjugal relationships as this would be likely to defeat their reasonable expectations (where they became subject to unexpected obligations) as well as compromise their autonomy. Typically, overseas jurisdictions have used the registration model, rather than the ascription model, to recognise non-conjugal relationships.

There are also concerns about applying the registration model to nonconjugal relationships, however. Ultimately, Chapter Four indicates that there have been no successful overseas examples of a registration model for nonconjugal relationships. There has been no uptake of such regimes in Vermont and Victoria to date. Tasmania only has two registered caring relationships. It is not impossible that these relationships might involve conjugal partners who have chosen to register their relationship as a caring relationship, rather than a significant relationship. Since these registration regimes were enacted, the state governments have shown little interest in monitoring the application and impact of the regimes on non-conjugal relationships (although the review body set up by the Vermont legislature recommended the disestablishment of that regime). In sum, it does not appear that registration schemes modelled on marriage are at all effective in recognising the needs of those in non-conjugal relationships.

However, if two people in a non-conjugal relationship wished to register their relationship under such a regime, understood the implications of doing so, and any implications for the state (in terms of the recognition of prohibited 
relationships and fiscal and other impacts on both the state and third parties) were addressed, there would be fewer concerns, as this approach would respect the autonomy of consenting, knowledgeable parties. It would be more desirable, however, if recognition were extended as a result of a comprehensive inquiry into the needs of people in such relationships, such as those in caregiving relationships or those sharing a home, so that rights and obligations were tailored to suit these relationships. It would not enhance respect for the law to create a legal registration scheme which was never used, as has happened over the last decade in Vermont. Such a project would necessitate an inquiry similar to that underlying the recognition of de facto relationships and civil unions in accordance with the Relationships (Statutory References) Act 2005.

However, it would also be possible to allow for recognition on a more limited basis, similar to the approach taken in the Protection of Personal and Property Rights Act 1988 (although under this Act, these relationships are not registered with a state respository). La Violette refers to this as the "blank slate plus" approach, as opposed to the "marriage minus" approach and suggests the former is more appropriate than the latter for people in non-conjugal relationships. ${ }^{21}$ The "blank slate plus" approach involves granting specific rights and obligations to individuals in a partnership, "without attempting to parallel marriage laws." 22

As indicated, it would also be important to first quantify the fiscal cost of a registration scheme to the state as well as assess how it might impact on society. This could include considering how the regime might affect conjugal or other family relationships, or whether it might encourage the formation of undesirable relationships such as incestuous relationships. The state might also need to consider whether the regime would have an impact on the state's objective of encouraging people to form conjugal relationships and any childbearing policies, although it is difficult to imagine a person forsaking the opportunity to enter into a conjugal relationship for the sake of preserving the legal recognition of a non-conjugal relationship.

\footnotetext{
${ }^{21}$ Nicole La Violette "Waiting in a New Line at City Hall: Registered Partnerships as an Option for Relationship Recognition Reform in Canada” (2002) 19 Can J Fam L 115 at 122. ${ }^{22}$ Ibid.
} 
However, it is unlikely that any such project will be a political priority in the foreseeable future, particularly given that New Zealand has already extended the marriage model to apply to same-sex and heterosexual de facto partnerships. In all the circumstances, the focus of any change should rather be on ensuring that policymakers have a framework within which they can properly consider which non-conjugal relationships might be relevant for a particular purpose.

\section{Case Study: Recognising Relationships between Informal Carers and Disabled Adults in New Zealand}

Before turning to consider the framework proposed below for recognising relationships for particular purposes, this thesis briefly considers the recognition of the relationship between informal caregivers and disabled adults in New Zealand, as an example of a non-conjugal relationship where legal recognition has been sought. A paper, The New Zealand informal caregivers and their unmet needs, was released in June 2010 by a prominent lobby group, following a decision by the Human Rights Tribunal that a Ministry of Health policy not to pay family members who provide support to disabled adult children was discriminatory on the grounds of family status under the Human Rights Act $1993 .^{23}$

Both the report and the case are considered below in terms of what they demonstrate about how the law might recognise non-conjugal relationships between informal caregivers and the disabled adults for which they care. This is a more specific type of caregiving than that which exists in relationships such as that between the elderly Burden sisters. However, these caregivers represent an identifiable interest group and their predicament is a good starting point for any state inquiry into the legal needs of caregiving relationships.

\section{A Atkinson v Ministry of Health}

In Atkinson v Ministry of Health, the nine plaintiffs comprised seven parents of disabled adult children who had provided long-term care to their

\footnotetext{
${ }^{23}$ Diane Jorgensen, Matthew Parsons, Stephen Jacobs and Hilary Arksey "The New Zealand informal caregivers and their unmet legal needs" (2010) 123 New Zealand Medical Journal 1; Atkinson v Ministry of Health (2010) 8 HRNZ 902.
} 
children, as well as two of the adult children. These parents sought a declaration that the Ministry of Health's policy of not funding parents, spouses and resident family members to care for disabled family members amounted to discrimination on the basis of family status under the Human Rights Act 1993. They considered that this policy excluded commercial carers from employment opportunities and denied their children the right to choose a family member as a paid caregiver. $^{24}$

The Ministry argued that its policy was a justified limitation on the right to be free from discrimination on the grounds of family status for a number of reasons. In particular, because the support services provided by family members were "natural supports" and should not attract payment. ${ }^{25}$ The Ministry argued that an aspect of the "social contract" between families and the state is that the family is regarded as the fundamental social unit but, in return, the state will not pay families to care for their own members. ${ }^{26}$ The Ministry considered that to propose otherwise could commercialise family relationships, create perverse incentives for families to refuse to provide care and for disabled persons to become overly dependent, and was fiscally unsustainable. ${ }^{27}$

The Tribunal rejected the justifications provided by the Ministry of Health. It observed that the Ministry sometimes made exceptions to this policy and that the Accident Compensation Corporation (ACC) provided most of its home support services through paid labour by family members. ${ }^{28}$ In addition, the Ministry and ACC had developed joint services specifications for the homebased care of disabled persons. ${ }^{29}$

This case raises a difficult question for government, as the state's interest in privatising dependency by encouraging unpaid family labour conflicts with human rights and equity considerations. Ultimately, the Tribunal, in finding in favour of the plaintiff adult carers, considered that caring for a disabled child into adulthood was beyond the normal social expectation of

\footnotetext{
${ }^{24}$ Ibid, at 907.

${ }^{25} \mathrm{Ibid}$, at 906.

${ }^{26}$ Ibid, at 908 .

27 Ibid.

${ }^{28}$ Ibid, at 100-113.

${ }^{29}$ Ibid.
} 
family caring. The Tribunal considered that it would be possible to constrain the fiscal impact of this decision by developing strategies such as treating payments on a clear exceptions basis. The Tribunal also recommended that the state develop an overarching carers' payment policy which should also apply to the care of the elderly in a home setting. ${ }^{30}$

The Ministry of Health is appealing this decision to the High Court and the hearing is set to commence on 13 September 2010. Carers New Zealand commissioned legal advice on the appeal which stated that a policy failure had resulted in $\mathrm{a}:{ }^{31}$

... gap between the estimated number of people entitled to receive disability support (291,000 in 2006) and the number of people who actually receive disability support. The 'gap' is estimated to be 29,000 who receive no funded care. There is an assumption that these people are either living independently with no care at all (apart from their natural supports), or that more extensive support services are being provided free by unpaid family or friends.

\section{$B \quad$ The Needs of Informal Caregivers}

Carers New Zealand suggests that the recent careers needs study "is one of the largest qualitative studies about carers in the world." 32 The aim of this study was to identify the characteristics and demographics of the New Zealand caregiver. $^{33}$ The study found that mothers and daughters undertake the majority of informal care, although ten per cent of informal caregivers in the study were not members of the immediate family. The largest group of care recipients were in the group aged 70 to 89 ( 29 per cent). A high proportion of carers in the study experienced stress and depression. The study observed that: ${ }^{34}$

\footnotetext{
When caregivers were asked how they were supported and what they thought would improve their lives and those of the care recipients their responses could be grouped into two main themes; comments about the support they were or were not receiving; and the impact of caregiving on their lives.
}

\footnotetext{
${ }^{30}$ Ibid, at 225 .

${ }^{31}$ John Forman “ Atkinson \& Others v Ministry of Health - Commentary" (legal advice, 8 February 2010.

${ }^{32}$ Carers NZ < carers.net.nz>.

${ }^{33}$ Jorgensen and others, above n 23.

${ }^{34}$ Ibid.
} 
Many were experiencing financial difficulties. Many also experienced social isolation as they had trouble taking time away from their caregiving duties. While other family members were initially supportive, assistance reduced over time. Caregivers primarily sought more financial assistance, flexible and reliable respite, as well as the opportunity and ability to be in paid employment.

It is clear that the types of schemes set out in Chapter Four would not meet the needs of the type of non-conjugal relationship experienced by informal carers and the people for whom they care. The Government recognises the specific need to support informal and formal caregiving relationships in their own right through the Carers' Strategy and Five Year Action Plan 2008. ${ }^{35}$ A discrete example of the type of legal assistance caregivers may desire is reflected in the overseas trend to allow "carers leave" for those carers in employment. To date, such measures have not been introduced in New Zealand. However, the Employment Relations Amendment Act 2008 gave workers with caring responsibilities the right to ask for flexible working arrangements. Under s 69AAB of the Employment Relations Act 2000, a person can make such a request when they have "the care of any person" after they have been with an employer for six months.

\section{The Relevance of Non-Conjugal Relationships to the Law}

Non-conjugal relationships may potentially be relevant to the following areas of law identified by the British Columbia Law Institute: ${ }^{36}$

- $\quad$ Employment issues: family-based financial benefits (basic and extended medical and dental care; pension and group life insurance plans; bereavement leave; sick leave; leave to care for a sick family member);

- $\quad$ Protection of the elderly;

- Conflicts of interest arising from family relationships;

\footnotetext{
${ }^{35}$ Ministry of Social Development.

${ }^{36}$ British Columbia Law Institute Report on Recognition of Spousal and Family Status (1999).
} 
- Healthcare issues (visiting rights; consent to healthcare; human tissue donation and autopsy decisions; decisions respecting burial or cremation);

- Information collection and privacy;

- Insurance issues (who is and is not protected under a policy by reason of being part of an insured's family);

- $\quad$ Prison (family visits);

- $\quad$ Accident compensation (who gets compensation);

- $\quad$ Social assistance benefits (income support policies; continuing care; sickness and disability benefits); and

- Wills and succession (status to be a personal representative, to share in an estate or to challenge a will).

The following discussion applies a framework for determining what personal relationships the law should recognise to some of these areas, namely: family provision, intestacy, sick and bereavement leave, joint family homes, domestic violence, pensions and accident compensation. The aim is to provide a basis for debate as to why and how non-conjugal relationships might be recognised by particular laws in New Zealand. The focus of this discussion is on very close non-conjugal relationships. However, this does not mean that the law is never interested in non-conjugal relationships that are less intimate. Ultimately, even a simple friendship may have legal consequences. This section takes a moment to consider the concept of a duty of care between friends.

While there do not appear to be any New Zealand cases on the duty of care between friends, Welstead identifies examples in the United Kingdom and Leib in the United States of America. ${ }^{37}$ Welstead observes that those in nonconjugal relationships like the Burden sisters generally do not owe a duty of care to each other. ${ }^{38}$ However, due to the nature of their living arrangements, she suggests that they might be "liable for the tort of negligence if they fail to care for each other when care is needed." 39 Welstead gives the example of a

\footnotetext{
${ }^{37}$ Welstead The Family the Law Forgot, above n 14; Ethan J Leib "Friendship and the Law" (2007) 54 UCLA 631 at 685.

${ }^{38}$ Welstead, Ibid, at 119.

${ }^{39}$ Ibid.
} 
British case where a mother and son lived together for a very long time, with the son giving up work to care for his mother. ${ }^{40}$ The mother fell ill and had a fall, after which she was incapacitated. However, her son did not call an ambulance until the following day. The son was charged with and pleaded guilty to manslaughter.

Leib also suggests that, in some circumstances, friends owe a duty of care toward each other. ${ }^{41}$ In particular, although the common law does not recognise a duty of stranger rescue, there may be such a duty between friends. Leib gives an example of a man who witnessed his friend being severely beaten. $^{42}$ He drove his friend to his friend's grandparents' house and left him there after failing to wake him up. His friend subsequently died because he did not receive medical attention for his injuries in time. The friend's estate sued for wrongful death and the court found in favour of the estate. Leib observes that: ${ }^{43}$

Perhaps we do not need the law to tell us to save our friends. But why shouldn't the law confirm what we already know to be true? It is perfectly sensible for the law to reinforce our well-accepted duties; it contributes to the law's affective resonance, and may have broader effects in facilitating compliance with the law's commands more generally.

Leib also suggests that there may sometimes be a duty between friends to disclose and deal fairly due to the fiduciary nature of their relationship. ${ }^{44} \mathrm{He}$ notes that while some courts do not treat friendship as capable of triggering such fiduciary duties, other courts take a different approach. He also identifies cases where third parties have had or sought standing to sue on behalf of someone with whom that party is closely associated, as well as cases where courts have recognised caregiving responsibilities for friends.

\footnotetext{
${ }^{40}$ Ibid. See Re Land (deceased) [2007] 1 All ER 324.

${ }^{41}$ Ethan J Leib "Friendship and the Law", above n 14, at 685.

${ }^{42}$ Ibid. See Farewell $v$ Keaton 240 NW 2d 217.

43 Ibid.

${ }^{44}$ Ibid.
} 


\section{Proposed Framework for Recognising Relationships}

The Law Commission of Canada proposes the following four step-test as an overarching framework for determining how to recognise close personal relationships: ${ }^{45}$

1. Legitimacy of law: Are the objectives of the law legitimate? If not, the law ought to be repealed or fundamentally revised.

2. Relevance of personal relationships: Do relationships matter? If the law's objectives are sound, are the relationships included in the law important or relevant to the law's objectives? If not, the law should not refer to any particular relationship but, rather, focus on the individual.

3. Self-selection of relationships by individuals: If relationships matter, can individuals be permitted to designate the relevant relationships themselves? If so, the law should allow individuals to choose which of their close personal relationships they want to be subject to the particular law.

4. Other ways of recognising relevant relationships: If relationships matter and self-designation is not feasible or appropriate, is there a better way to include relationships? Can the law be revised to more accurately capture the relevant range of relationships? If so, an appropriate mix of relationships status and functional tests should be used to identify relevant relationships.

This framework is based on principles similar to those outlined in Chapter One and is designed to allow for better legal recognition of nonconjugal relationships. The first question should form part of any robust policy analysis exercise. However, the Law Commission then proposes that states should take a "step back" and determine whether relationship status is actually

\footnotetext{
${ }^{45}$ Law Commission of Canada Beyond Conjugality (2001) at 29 to 36.
} 
relevant to a particular policy. ${ }^{46}$ This should occur whether or not the policy objective is legitimate. ${ }^{47}$ Ultimately, the Law Commission asks whether we can "imagine a legislative regime that accomplishes its goals more effectively by relying less on whether people are living in particular kinds of relationships."48

If relationships are relevant, the self-designation approach suggested by the Law Commission supports principles of autonomy and voluntariness as well as the principle of privacy. ${ }^{49}$ It allows people the freedom to decide which of their relationships are important. However, sometimes self-selection will not support the achievement of a particular policy aim. In that case, the state should consider carefully how personal relationships could be specified for the purposes of the law. Here, it may be appropriate to allow an individual to opt in (by registering their relationship and gaining a particular status) or ascribe rights and duties. These tests should not focus exclusively on marital and marriage like relationships, but should be prepared to recognise a range of economically and emotionally interdependent relationships. It may be necessary to develop a new test or establish a new relationship status to achieve this.

The Law Commission advocates a test based primarily on economic interdependency and emotional intimacy, although the Law Commission suggests that sharing a house could also be a relevant consideration. ${ }^{50}$ However, in some relationships that are relevant to the law, there may be no financial interdependence and parties may not live together. For example, bereavement leave, which derives from the emotional intimacy between the bereaved and the deceased. The list of factors for identifying whether a de facto relationship exists may be a starting point for identifying what relationships are relevant, but policymakers should not apply these at the expense of developing innovative solutions.

It was suggested in Chapter Two of this thesis that important nonconjugal relationships may be considered family relationships. Family status

\footnotetext{
${ }^{46}$ Ibid at 29.

${ }^{47}$ Ibid

48 Ibid

${ }^{49}$ Ibid, at 32.

${ }^{50} \mathrm{Ibid}$, at 34.
} 
could also become a mechanism for recognising non-conjugal relationships. A family status model would allow "family-like" relationships to be recognised and could even allow people to designate the people with whom they have a family relationship, by extending the model underpinning the Protection of Personal and Property Rights Act 1988 (as discussed in Chapter Three) to allow people to nominate important relationships for other legal purposes. "Household members" could also be used to identify relationships where cohabitation is a relevant factor. This thesis now turns to apply the framework to various areas of New Zealand law.

\section{A Family Provision: Family Protection Act 1955}

In New Zealand, the Family Protection Act 1955 allows close relatives to challenge a will if they feel that the deceased has not adequately provided for them. This approach is based on the privitisation of dependency, which requires that other family members meet the needs of dependent family members. The Act recognises that a person may be entitled to a share of a deceased's estate where the deceased has a moral duty to provide for them. A moral duty can be of both a financial and sentimental nature. This has lead to some people alleging that the Act is outdated and that testamentary freedom should not be overridden by such considerations. The New Zealand Law Commission was directed to undertake a review of the Act in 1993 in order to give "better effect to the intentions of will-makers, and take account of the diversity of New Zealand families", although the Act was not subsequently amended. ${ }^{51}$

This thesis does not consider whether the objective of this law is valid as the framework for recognising relationships can be applied regardless of whether the objective is valid or not. However, this controversy does mean that any argument to extend the range of relationships to which this Act applies could be subject to a revision of the objective of the Act. Grainer, who advised the Law Commission on its review, suggests that the concept of "moral duty" should be replaced by "a more clearly defined test based on dependence and

\footnotetext{
${ }^{51}$ See Law Commission Succession (NZLC R41, 1997).
} 
need." ${ }^{, 52}$ However, it may be difficult for one adult to prove dependency on another, even in spousal relationships.

In applying the framework suggested by the Law Commission of Canada, the testator's freedom must be balanced against the claimant's needs. Currently, the Act allows only a limited range of people the legal status to bring a claim. In accordance with s 3 of the Act, the only people entitled to claim are spouses, civil union and de facto partners, children, grandchildren, stepchildren and parents. If somebody else wishes to make a claim they must bring a case under the Law Reform (Testamentary Promises) Act 1949. This Act is of very limited applicability and only covers the situation where a person has provided work or services for a deceased person who has either expressly or impliedly promised to provide for them in that person's will.

To begin with, given the objective of the Family Protection Act, there is an argument that family provision claims should not be limited to the relationships specified. For example, siblings, such as the Burden sisters, are excluded from the operation of the Act, although parents are included. Sibling relationships may involve significant emotional intimacy and financial interdependency, and are recognised in other areas of the law. There are no clear grounds for distinguishing between parental and sibling relationships. It could be suggested, therefore, that the Act should be expanded to, at least, include siblings and other such relationships, or even all household members who are in a relationship of emotional and financial dependence or interdependency with the deceased.

This approach would continue to balance testamentary freedom with equitable considerations relating to a deceased's responsibilities, but would ensure that an appropriate range of relationships could be recognised, rather than privileging the current list of family members "over and above other people". 53 This approach also acknowledges the increasing diversity of family and other relationships and recognises the state's interest in supporting and

\footnotetext{
${ }^{52}$ Virginia Grainer "Is Family Protection a Question of Moral Duty?" (1994) 24 VUWLR 141 at 141.

${ }^{53} \mathrm{Ibid}$, at 151 .
} 
promoting informal care and close relationships, particularly where the claimant provided an extensive degree of care and support to the deceased.

There would be a low risk of abuse if this approach were adopted, as it would be difficult for people such as flatmates to demonstrate the required emotional and financial interdependency not to mention difficulties in establishing that they had standing to bring a claim. While it would be possible for people in the situation of the Burden sisters to take a claim under the Testamentary Promises Act, on the basis of an implied promise to compensate for caring provided, it is debatable whether people in relationships of emotional and financial dependency should need to rely on such a limited provision which conceives of relationships in terms of services performed.

In addition, it is difficult to make out a claim under this Act due to the fact that a deceased may make a promise to a family member out of love and affection rather than in return for services provided. ${ }^{54}$ Under the Act, families need to establish that their "services" were not those involved in a normal family relationship, but went further. ${ }^{55}$ Where a claimant is not family, but was treated as a family member, their "services" will be assessed in the same way. ${ }^{56}$ Sutton and Peart suggest that testamentary claims by adult children are a "vexed matter". 57

Of the approach taken in the United Kingdom, Walstead observes that a person (including a sibling) may apply for financial provision under the Inheritance Act 1975 if they can show that reasonable financial provision has not been made for that person by a deceased. ${ }^{58}$ They must show that the deceased was maintaining them in order to apply, although couples do not need to establish this and a different definition of reasonable financial provision applies to them (for couples, this is what is reasonable in all the circumstances of the case, whereas for siblings, this is what is reasonable for the purpose of

\footnotetext{
${ }^{54}$ See Re Welch [1990] 3 NZLR 1 and Samuels v Atkinson [2009] NZCA 556.

${ }^{55}$ Samuels v Atkinson [2009] NZCA 556.

${ }^{56}$ Ibid.

${ }^{57}$ Richard Sutton and Nicola Peart "Testamentary Claims by Adult Children - The Agony of the "Wise and Just Testator" (2003) 10 Otago LR 385 at 385.

${ }^{58}$ Welstead "The Family the Law Forgot", above n 14, at 121.
} 
maintenance). ${ }^{59}$ Welstead notes that the British Law Commission has provisionally recommended that an assumption of responsibility by the deceased should not be a threshold requirement, but should simply be one of the factors taken into account. ${ }^{60}$

\section{B Intestacy: Administration Act 1969}

Intestacy law determines who inherits property from the estate of a person who dies without a will. Relationships are relevant for this purpose. Self-selection cannot work for this area of law because the deceased dies without making a decision about which of the deceased's relationships are relevant for inheritance purposes. It is important to provide for a clear and certain way of distributing a deceased's estate upon intestacy.

In New Zealand, intestacy law is set out in the Administration Act 1969. Spouses, civil union partners, de facto partners and children have statutory priority. ${ }^{61}$ Following these relationships, the Act sets out classes of relatives, starting with parents, then siblings, then grandparents, uncles and aunts. In the penultimate instance, property will revert to the Crown. Out of this, the Crown can provide for "dependants (whether kindred or not) of the intestate" and "other persons for whom the intestate might reasonably have been expected to make provision." 62

This approach provides a certain and clear order of priority for intestate succession, which is important to limit the disputes that might arise upon intestacy. However, the privileging of certain relationships over others is somewhat arbitrary. While it is understandable that spouses, partners, and children are given statutory preference, it is less clear why certain relatives are given preference over others as well as non-relatives. While this order of priority may reflect living arrangements in some families it may not reflect those in others. Arguably, household members who were in a close relationship of emotional and financial dependence or interdependence with the deceased

\footnotetext{
${ }^{59}$ Ibid, at $121-123$.

${ }^{60}$ Ibid, at 122. See Law Commission Intestacy and Family Provision Claims on Death (CP 191, 2009).

${ }^{61}$ Administration Act 1969, s 77.

${ }^{62}$ Ibid.
} 
might take precedence over certain other family members, or would have if the deceased had made a will. This would be particularly so where cohabitation has been lengthy and characterised by caring and intimacy. This Act reflects a very traditional understanding of family and personal relationships, although recognition is more expansive than in the Family Protection Act 1955.

Intestacy in the United Kingdom is governed by the Administration of Estates Act 1925. In contrast, where there is no will and two siblings are cohabiting (or an adult child is cohabiting with a parent), a sibling or adult child can inherit from the deceased's estate under intestacy rules, if the deceased had no spouse or civil partner (or child, in the case of a sibling). The adult child will inherit in equal shares with any other sibling, but their claim is not subject to the priority of a non-cohabiting parent.

In 2009, the British Law Commission considered whether non-conjugal relationships such as those between cohabiting siblings or an adult child and parent who are living together, should receive statutory priority. ${ }^{63}$ The Commission considered that the law already provided adequately for such relationships and that, unlike conjugal relationships, living arrangements were too diverse to formulate a standard rule. In response to this, Walstead observes that: ${ }^{64}$

It is unfortunate that the Law Commission did not take the opportunity in its consideration of the current problems of intestate succession to look more closely at the similarity of the problems faced by consanguineal couples and cohabitants.

\section{Bereavement and Sick Leave: Holidays Act 2003}

Bereavement leave requires that employers respect the need of employees to mourn the passing of someone with whom an employee had a close relationship. The objective of this law is legitimate and relationships are clearly relevant to its operation. There are some concerns with respect to the degree of self-selection of relationships allowed for the purposes of this law. Bereavement leave is a cost to employers and there is a need to ensure the

\footnotetext{
${ }^{63}$ Law Commission Intestacy and Family Provision Claims on Death (CP 191, 2009).

${ }^{64}$ Welstead "The Family the Law Forgot", above n 14, at 121.
} 
statutory regime is not open to abuse. Legislation can provide some certainty that this will not be abused by requiring a close relationship between the bereaved and the deceased.

The Current position in New Zealand is set out in s 69 of the Holidays Act 2003. Any employee is entitled to take bereavement leave if they suffer bereavement. This specifically includes the loss of a spouse or partner, parent, child, brother or sister, grandparent, grandchild or spouse's (or partner's) parent. ${ }^{65}$ However, bereavement also includes the death of any other person if the employer accepts that the employee has suffered bereavement as a result of the death. ${ }^{66}$ Examples of relevant factors to take into account are: the closeness of the association between the employee and the deceased person; whether the employee has to take significant responsibility for all or any of the arrangements for the ceremonies relating to the death; and any cultural responsibilities of the employee in relation to the death. ${ }^{67}$

The New Zealand approach strikes a balance between providing some certainty by specifying key relationships as well as allowing sufficient flexibility for employees to obtain bereavement leave if someone they are close to dies. However, s 70 provides that if the bereavement relates to one of the specified relationships, three days of leave will be permitted. If not, only one day is permitted. This distinction is arbitrary. It is possible to envisage a situation where a relationship outside of those specified relationships causes an equally great bereavement. The rationale for this distinction is likely to be to limit the financial liability of employers by specifying a range of relationships where a greater bereavement is considered likely to arise. However, the prioritisation of certain family relationships may not align with how an individual views their own personal relationships.

It could be suggested that this approach is inconsistent with the Human Rights Act 1993, which prohibits discrimination on the basis of family status, which includes relative. Relative, as defined, includes a wider variety of

\footnotetext{
${ }^{65}$ Holidays Act 2003, s 69(2)(a).

${ }^{66}$ Ibid, s 69(2)(b).

${ }^{67}$ Ibid, s 69(3).
} 
relationships than those specified in the Holidays Act. It is questionable whether employees are likely to abuse such a policy. First, there must be a death and second, the employer will be able to assess the impact of the bereavement on the employee. As such, this is an instance where it would be appropriate to treat close non-conjugal relationships in the same manner as other family relationships. Therefore, the law should allow for an equivalent period of bereavement leave for both the specified and non-specified relationships to which the Act applies.

The Holidays Act 2003 also governs sick leave in New Zealand. ${ }^{68}$ Sick leave recognises the domestic responsibilities of employees and that employees perform informal care duties that benefit society. The objective is to support employees to carry out these responsibilities. Section 65 provides that an employee may take sick leave if they are sick or injured, if their spouse or partner is sick or injured, or if a person who depends on the employee for care is sick or injured. With respect to the last category of relationship, the Holidays Act 1981 previously limited the recognition of dependents to the dependent children or dependent parents of a worker.

The policy objective of this law is legitimate and relationships are relevant to the objective. There is a need to limit the fiscal liability of employers so that employees only take sick leave where this is reasonable to care for another. What a relationship of dependency entails is a matter of fact and degree and it is unclear if the employee must show that the sick person is dependent on them (as opposed to another person). There may be other people that could assist the sick person, but, in the circumstances, the employee may be the only person able to provide necessary support at that particular time. On balance this law may sufficiently address the needs of those in non-conjugal relationship, provided that dependency is reasonably assessed taking all the circumstances into account.

\footnotetext{
${ }^{68}$ Ibid, s 65.
} 


\section{Joint Family Homes: Joint Family Homes Act 1964}

A "special type of joint ownership arises when a married couple settles the title to their home as a joint family home." $" 69$ This Act provides a married couple with limited protection against claims in respect of their family home by unsecured creditors. If one spouse owns the house, the Act also allows that spouse to gift a half share to the other without paying gift duty. Section 2 of the Act provides that husband and wife "in relation to any settled property, means the husband and wife on whom the property is settled under this Act." As such, the Act does not apply to civil union partners or to de facto partners.

In practice, the Act allows a spouse a protected sum of $\$ 103,000$ from the proceeds of the sale of the home to satisfy the other spouse's unsecured creditors (this protection does not apply against secured creditors). ${ }^{70}$ In fact, this may make the Act "less attractive than creating a family trust", as a trust typically provides a greater level of protection against creditors. ${ }^{71}$ A transfer of property in similar circumstances can also be achieved under the Property (Relationships) Act 1976, and gift duty is also not payable on such a transfer.

This Act raises questions with respect to whether it has a legitimate objective, whether relationships are relevant to the objective and whether people should be able to self-select which of their relationships matter (if relationships are relevant). To begin with, in 2001, the Law Commission considered whether there was a continuing need for the Act and whether it should be extended to de facto and same-sex partners. ${ }^{72}$ In its discussion paper, the Law Commission acknowledged that the objective of the Act was to secure the marital home from being sold to satisfy debtors, in order to promote marriage at a time when de facto relationships were becoming more prevalent. ${ }^{73}$

Originally, the benefits of the Act included an exemption from stamp duty, estate duty and gift duty. However, stamp and estate duty have been abolished and it is likely that gift duty will also be abolished. (and can be

\footnotetext{
${ }^{69}$ Nicholas Drake, Janine Lay, Sally Varnham and Cordelia Thomas Conveyancing Law Handbook ( $3^{\text {rd }}$ ed, CCH, Auckland, 2007) at 113.

${ }^{70}$ Ibid, 114.

${ }^{71}$ Ibid.

${ }^{72}$ Law Commission The Future of the Joint Family Homes Act (NZLC PP 44, 2001).

${ }^{73}$ Ibid, at 2.
} 
avoided, in any event, through using the provisions of the Property (Relationships) Act 2001). The Law Commission also indicated that registration under the Joint Homes Act means that, if one spouse dies, the other spouse does not have to go through the probate process as they would under the Property (Relationships) Act $2001^{74}$, as their interest automatically converts to sole ownership under the Joint Homes Act.

The Law Commission raised questions about the legitimacy of the objective of the Act, the relevance of relationships to the Act and the implications of confining its scope to spouses. With respect to the latter, marital status is a prohibited ground of discrimination under the Human Rights Act 1993. The Commission considered that there was no clear policy rationale for not extending the Act to de facto partners and that the Act was discriminatory. ${ }^{75}$ The Commission considered this a reason to repeal the Act.

In the Commission's final report released later that year, the Commission also considered that, even if the Act were extended to de facto partners, "its provisions would still discriminate against those who choose or are compelled by circumstances to live without partners." benefit under the Act that excluded sole owners discriminatory. It recommended the repeal of the Act and suggested a new "blanket protection (up to the amount of the specified sum) of a bankrupt's principal dwelling house." The Commission considered that this would allow for the protection of "necessary tools of trade" and "household furniture and effects". The Commission observed that in certain other jurisdictions, single persons were able to make such a claim (though their entitlements might be less than those of married persons or those living with family members).

If the Law Commission's reasoning is adopted, leaving aside the question of whether the objective of the law is legitimate, relationships are not relevant to achieving the objective of the Act. While the Commission did not consider the extension of the Act to other family members, it did observe that

\footnotetext{
${ }^{74}$ Then the Matrimonial Property Act 1976.

${ }^{75}$ Ibid, at 16.

${ }^{76}$ Law Commission The Future of the Joint Family Homes Act (NZLC R 77, 2001), at 7.

${ }^{77}$ Ibid, at 8 .
} 
the provisions were not just discriminatory against other conjugal relationships, but also against people not in conjugal relationships.

But is it possible that people in a non-conjugal relationship might wish to register their house under the Joint Homes Act? It is not inconceivable that sisters in a relationship such as that between the Burden sisters might wish to do so. Certainly, people in non-conjugal relationships sometimes have an equitable interest in property to which they do not have title. In Riddles $v$ Jones, an elderly mother purchased a house with her daughter, using the mother's divorce settlement in part, although the daughter was the sole registered owner. ${ }^{78}$ The daughter agreed to provide a house for her mother for life but their relationship broke down and the daughter evicted her mother. The court held that the mother had a beneficial interest in occupying the house during her lifetime.

Similarly, in Morgan v Morgan, the High Court held that a deceased mother had an equitable interest in property held by a married couple (who were separated at the time of the case, the daughter being the executor of her mother's estate), although this only amounted to a right to occupy the house for life, rather than a proprietary share. ${ }^{79}$ The High Court did not decide the case in the first instance, requiring further factual information. However, it later ruled that: ${ }^{80}$

I do not consider that the parties must be taken reasonably to have expected that Mrs Williams would share in the Kelburn property to the extent of retaining a beneficial interest in the property extending beyond the right to live in the flat during her life time.

On balance, it is arguable that a wider range of family relationships or close personal relationships could benefit from protection under the Joint Family Homes Act, as people in non-conjugal relationships do share and buy property together. As suggested by the Law Commission, however, the most appropriate response may be that personal relationships are irrelevant to the Joint Homes Act, and that protection against creditors should apply equally to all people whether they are in a relationship or not.

\footnotetext{
${ }^{78}$ Riddles $v$ Jones (High Court, Nelson, CP 39/88, 20 June 1990).

${ }^{79}$ Morgan v Morgan HC Wellington CIV-2008-485-2494, 4 June 2009.

${ }^{80}$ Morgan v Morgan HC Wellington CIV-2008-485-2494, 13 October 2009 at [28].
} 


\section{E Domestic Violence: Domestic Violence Act 1995}

As outlined in Chapter One, New Zealand recognises a range of close personal relationships for the purposes of a protection order under the Domestic Violence Act 1995. However, the New Zealand approach previously distinguished between conjugal and non-conjugal relationships and in $G v G$, the Court refused to grant a non-molestation order (the equivalent of a protection order under the Domestic Protection Act 1982) to a mother against her son, because protection was limited to a "man and woman, living together in the same household". ${ }^{81}$ The Court ruled that this was intended to refer to a spousal relationship, not a parental or sibling relationship.

An application of the framework supports the approach taken by New Zealand. Domestic Violence legislation is an example of an area of law where protection should depend on intimacy, not formal relationship status. Some of the overseas reforms outlined in Chapter Four extended the protection of domestic violence laws that previously only recognised spouses. However, in places like Vermont, protection was only extended to those who registered their relationship. Welstead observes that couples are treated differently from other domestic relationships for the purposes of British domestic violence legislation. $^{82}$ In particular, those who are not a couple have fewer of the civil remedies related to occupation of the family home under the Family Law Act 1996. However, Welstead notes that "there is an equal playing field" for orders known as non-molestation orders, to protect people from any physical or mental violence of a partner (be this a spouse or a non-conjugal partner). ${ }^{83}$

In contrast to the British approach, s 52 of the Domestic Violence Act allows an occupation order to be sought by anyone in a domestic relationship provided that, at the time the order is made, either party to the proceedings owns or has a legal interest in the property. As such, the protected person has a right to continue cohabitation regardless of whether they own or have an interest in the property or not. This ensures that they are not penalised by reason of a protection order made against a person who owns the house they share.

\footnotetext{
${ }^{81} G v G$ HC Wellington M682/85, 2 November 1987.

${ }^{82}$ Mary Welstead "The Family the Law Forgot", above n 14, at 119.

${ }^{83}$ Ibid, at 120 .
} 


\section{F Pensions: New Zealand Superannuation and Retirement Income Act 2001}

New Zealand Superannuation is a pension paid by the state to most New Zealand residents from age 65 in accordance with the New Zealand Superannuation and Retirement Income Act 2001. Under s 80BD(4) of the Social Security Act 1964, a pension ends either upon death or four weeks after death if a spouse, partner or child survive the deceased. Payment of a benefit to a surviving spouse, partner or child is known as a termination grant. This fourweek period also applies to a veteran's pension, a widow's pension, the domestic purposes benefit, an invalid's benefit, an independent youth benefit, an unemployment benefit, a sickness benefit, or a related emergency benefit. ${ }^{84} \mathrm{~A}$ termination benefit is not available if there is an entitlement to a survivor's grant under the Accident Compensation Corporation Act 2001.

The objective of this legislation is ostensibly to allow a surviving spouse or child a period of time to adjust to financial changes following the loss of income resulting from the death of the person receiving superannuation. Relationships are clearly relevant to this objective. However, it could be argued that a termination payment is unfairly limited to spouses. For example, an elderly person could also be affected by loss of income following the death of a close friend with whom they have been living for a long time. In this respect, the Australian federal government amended Australia's superannuation and tax laws in 2004 to recognise people in an "interdependency relationship" as dependants who can receive tax-free superannuation death benefits. ${ }^{85}$

Under this approach, two people are in an interdependency relationship if they have a close personal relationship, reside together, one or each of them provides the other with financial support, and one or each of them provides the other with domestic support and personal care. Two people are also in an interdependency relationship if they have a close personal relationship but are unable to satisfy the other elements of the definition because of a disability.

\footnotetext{
${ }^{84}$ Social Security Act 1964, s 80BD.

${ }^{85}$ Superannuation Industry (Supervision) Act 1993, s 10(1) and 10A. See also Superannuation Industry (Supervision) Regulations 1994, 1.04AAAA for a breakdown of matters that can be taken into account.
} 
There are two arguments, however, in favour of limiting the eligible pool of beneficiaries to spouses and children. The first is that the fiscal implications of paying a termination benefit to all cohabitants could be significant and might result in welfare reductions in other areas. If a distinction can generally be drawn between the degree to which people in conjugal and non-conjugal relationships share their lives, as suggested in Chapter Two, then this is a particular benefit that should be more closely linked to the sharing of lives than factors such as long-term cohabitation. It might also be impractical to extend legal recognition on the basis of functional criteria, particularly given the relatively low value of the payment and the complexity involved in determining whether relationships fall within functional criteria.

Second, many benefits targeted toward spouses and partners recognise that, in conjugal relationships where there are children, one partner may give up educational and employment opportunities to carry out caregiving duties. For example, while the payment of a pension terminates after four weeks, it is possible for a woman whose spouse or partner died to receive a widow's benefit. This depends on whether she has dependent children, if she has had dependent children in the past, the age at which her spouse or partner died and how long they were married or in that relationship. The right to a termination benefit could be seen as a counterpart to other obligations taken on by many, though not all, conjugal partners such as childbearing and childrearing. As such, there is an argument that the termination benefit for a pension also reflects this approach and that its limitation to conjugal partners can be rationalised.

\section{G Fatal Accidents: Accident Compensation Act 2001}

Survivors' grants recognise the loss suffered by people in relationships with an immediate victim. ${ }^{86}$ They serve a legitimate purpose and are intricately connected with relationships. Section 69 of the Accident Compensation Act 2001 allows funeral grants, survivors' grants and weekly compensation to be paid to the spouse or partner, or children and other dependants of a deceased claimant. Other dependent means a person who, because of his or her physical or mental condition, was financially dependent on the deceased claimant, is

\footnotetext{
${ }^{86}$ Law Commission of Canada Beyond Conjugality, above n 2, at 37.
} 
earning less than the minimum weekly earnings set by the Accident Compensation Corporation, is not the deceased's spouse or partner and is not a child of the deceased aged under $18 .^{87}$

Again, it could be argued, as in the case of termination payments, that this approach is directly linked to the financial difficulties that may result where a deceased leaves behind a dependent child or a spouse who gave up employment and educational opportunities to care for children. Of course, if this were so, it would be possible to link eligibility directly to these factors. However, it is not so linked, and spouses and partners do not need to meet any criteria to be eligible for compensation. While it would not be appropriate for the state to pay a benefit to a range of people with whom the deceased was in a close relationship, the situation where an unmarried deceased is in a long-term non-conjugal relationship might be different.

While the Act allows for the recognition of non-conjugal relationships, this is only on the basis that the surviving person was financially dependent on the deceased and unable to provide for him or herself (for example, due to mental illness). A similar approach is taken under the Fatal Compensation Act 1976 (UK), which only recognises marital relationships, civil partnerships and de facto relationships. This clearly results in differential treatment between spouses and those in non-conjugal relationships. The approach may differ in countries where the state does not pay survivor benefits as the right to sue for personal injury still exists. In such cases, it might be possible for a person in a non-conjugal relationship to initiate proceedings, even though these might be unsuccessful.

\section{H Summing Up: The Significance of Fiscal Implications}

These are not the only legal areas in which it can be debated that a broader range of relationships should be recognised by the law. Other areas such as tax and immigration are also important areas where the state provides benefits to people in conjugal relationships that other people in close nonconjugal relationships cannot access. It may be observed, however, that in areas

\footnotetext{
${ }^{87}$ Accident Compensation Corporation 2001, s 6.
} 
where relationship recognition has fiscal implications for the state, the recognition of personal relationships tends to be limited to conjugal relationships, although non-conjugal relationships in which there is a high degree of dependency or caregiving may also, though not always, be recognised.

However, in areas where relationship recognition has fiscal implications for third parties (such as employers or other family members), rather than the state, the law appears to more readily recognise a narrow range of non-conjugal relationships, though this is principally limited to close family relationships, rather than family-like relationships. In contrast, in legal areas that do not have fiscal implications, the law increasingly recognises a wider range of relationships, though there is, by no means, consistency in the approach taken by different legislative provisions to identifying relevant relationships. Ultimately, this thesis recommends a more comprehensive and principled approach to the legal recognition and support of the full range of close personal relationships that may be experienced among adults.

\section{Conclusion}

This thesis suggests that the legal recognition of non-conjugal relationships in New Zealand could be improved. The basic question that this thesis considered was whether the marriage model should be extended to include certain non-conjugal relationships in New Zealand, as it has been in countries such as Australia, Canada and the United States of America. This thesis asks this question at a time where the distinction between conjugal and non-conjugal relationships has been destabilised, due to the de-emphasis of sexual intimacy as a criterion for recognising marriage-like relationships.

Although there is little demographic information available about nonconjugal relationships, it is clear that they can exhibit many of the features associated with conjugal relationships, as demonstrated by the high profile Burden sisters' case in the United Kingdom. These include characteristics such as long-term cohabitation, caring, commitment and interdependency. However, non-conjugal relationships typically exhibit these features to a lesser degree, 
which means that they may have different needs and require different support from the state.

Ultimately, this thesis does not recommend extending the marriage model to non-conjugal relationships in New Zealand, either by registration or ascription, for a number of reasons. The primary concern is that the marriage model does not appear to respond adequately to the needs or living arrangements of people in non-conjugal relationships. However, non-conjugal relationships in New Zealand can benefit from legal recognition in some cases. Aside from human rights considerations, the state has an interest in promoting these relationships due to their contribution to social cohesion and informal caregiving. Yet there is no overarching framework to assist the state to determine which personal relationships are relevant to the law, and a haphazard approach has been taken to date.

As such, this thesis recommends a new framework for recognising personal relationships that also allows for non-conjugal relationships in New Zealand to be supported and promoted by the law, where appropriate. This framework was applied to a number of areas of New Zealand law in order to provide a basis for future debate. 


\section{Bibliography}

\section{Texts}

Badgett, M V Lee When Gay People Get Married: What happens when societies legalize same-sex marriage (New York University Press, New York, 2009).

Bottomley, Anne and Wong, Simone Changing Contours of Domestic Life, Family and Law: Caring and Sharing (Hart Publishing, Oxford, 2009).

Brook, Heather Conjugal Rites: Marriage and Marriage-like Relationships before the Law (Palgrave Macmillan, New York, 2007).

Choudhry, Shazia and Herring, Jonathan European Human Rights and Family Law (Hart Publishing, Oxford, 2010).

De Cruz, Peter Family Law, Sex and Society: A Comparative Study of Family Law (Routledge, London, 2010).

Diduck, Alison and O'Donovan, Katherine (eds) Feminist Perspectives on Family Law (Routledge-Cavendish, Arbingdon (United Kingdom), 2006).

Eekelaar, John Family Law and Social Policy $\left(1^{\text {st }}\right.$ ed, Weidenfeld \& Nicholson, London, 1989).

Finlay, Henry To Have But Not To Hold: A History of Attitudes to Marriage and Divorce in Australia 1858-1975 (The Federation Press, Sydney, 2005).

Giddens, Antony The Transformation of Intimacy: Sexuality, Love \& Eroticism in Modern Societies (Polity Press, London, 1992).

Nayar, R Jayakumar "Not another Theory of Human Rights" in C Gearty and A Tomkins (eds) Understanding Human Rights (Continuum, London, 2000).

Perry, M The Idea of Human Rights (Oxford University Press, New York, 1998).

John Rawls A Theory of Justice (Oxford University Press, New York, 1971).

Regan, Milton C Alone Together: Law and the Meanings of Marriage (Oxford University Press, New York, 1999).

Stark, Barbara International Family Law: An Introduction (Ashgate Publishing Limited, Hants (England), 2005).

Stone, Deborah Policy Paradox: The Art of Political Decision Making $\left(2^{\text {nd }}\right.$ ed, Norton \& Company, New York, 2002). 
Welstead, Mary "England and Wales: The Family the Law Forgot" in Bill Atkin (ed) The International Survey of Family Law 2010 Edition (Jordans, Bristol, 2010).

Wilson, Margaret and Hunt, Paul (eds) Culture, Rights, and Cultural Rights: Perspectives from the South Pacific (Huia Publishers, Wellington, 2000).

\section{Journal articles}

Anderson, Thomas G "Comment on the Report of the British Columbia Law Institute on Recognition of Spousal and Family Status" (2000) 12 CJWL 439.

Anderson, Thomas G "Models of Registered Partnership and their Rationale: The British Columbia Law Institute's Proposed Domestic Partner Act" (2000) 17 Can J Fam L 89.

Atkin, Bill "The legal world of unmarried couples: reflections on "de facto relationships" in recent New Zealand legislation” (2009) 39 VUWLR 793.

Auchmuty, Rosemary "Beyond Couples: Burden v United Kingdom (2008) 47 EHRR 38; [2008] 2 FLR 787; Grand Chamber of the European Court of Human Rights, 29 April 2008” (2009) 17 Fem Leg Stud 205.

Austin, Graeme W "Essay: Family Law and Civil Union Partnerships - Status, Contract and Access to Symbols" (2006) 37 VUWLR 183.

Bailey, Martha (2004) "Regulation of Cohabitation and Marriage in Canada" Law \& Pol'y 153.

Bala, Nicholas "Controversy over Couples in Canada: The Evolution of Marriage and Other Adult Interdependent Relationships" (2003-2004) 29 Queens LJ 41.

Ball, Carlos A "Against Neutrality in the Legal Recognition of Intimate Relationships” (2008) 9 GJGL 321.

Beck, Ulrich and Beck-Gernsheim, Elisabeth Individualization (Sage Publications, California, 2001).

Beck, Ulrich and Beck-Gernsheim, Elisabeth The Normal Chaos of Love (Polity Press, Cambridge, 1995).

Behrens, Juliet "Book Review: The Neutered Mother, the Sexual Family and Other Twentieth Century Tragedies" (1996) 10 AJFL 272.

Bennett, Christopher “Autonomy and Conjugal Love: Reply to Golash" (2006) 12 Res Publica 191. 
Bennett, Christopher "Liberalism, Autonomy, and Conjugal Love" (2003) 9 Res Publica 285.

Bieliauskas, Vytautus J "Masculinity, Femininity, and Conjugal Love" (2005) $10 \mathrm{~J}$ of Rel and Health 37.

Cherlin, A J "The desinstitutionalization of American Marriage" (2004) 36 J Marriage and Fam 848, as cited in Caroline A Thomas "the Roles of Registered Partnerships and Conjugality in Canadian Family Law" (2006) 22 CJFL 223.

Cohen, Lloyd "No-fault family law: A problematic ideology (should family law promote marriage as the ideal?" NJLJ (26 January 2007).

Cossman, Brenda "Contesting conservatisms, family feuds and the privitization of dependency” (2005) 13 Am U J Gender Soc Pol’y \& L 415.

Cossman, Brenda and Ryder, Bruce "What is Marriage-Like Like? The Irrelevance of Conjugality” (2001) 18 Can J Fam L 269.

Cross, Jane E, Palmer, Nan and Smith, Charlene L "Families Redefined: Kinship Groups That Deserve Benefits" (2008-2009) 78 Miss LJ 791.

Duff, David G "Recognizing or Disregarding Close Personal Relationships Among Adults? The Report of the Law Commission of Canada and the Federal Income Tax (Policy Forum: Comments on the Law Commission of Canada's 'Beyond Conjugality: Recognizing and Supporting Close Personal Adult Relationships)" 50 Can Tax L J 1021.

Drake, Nicholas; Lay, Janine; Varnham, Sally and Thomas, Cordelia Conveyancing Law Handbook ( $3^{\text {rd }}$ ed, CCH, Auckland, 2007).

Eekelaar, John and Maclean, Mavis "Marriage and the Moral Bases of Personal Relationships” (2004) 31 JLS 510.

Ettelbrick, Paula L "Domestic Partnership, Civil Unions, or Marriage: One Size Does Not Fit All” (2001) 64 Alb L Rev 905.

Fineman, Martha "Contract and Care (Symposium on the structures of care work" (2001) 76 Chicago-Kent L Rev 1403.

Fineman, Martha "Masking dependency: the political role of family rhetoric (Symposium: New Directions in Family Law)" (1995) 81 Va L Rev 2181.

Fineman, Martha "What place for family privacy? (Privacy and the Law: A Symposium” (1999) 67 Geo Wash L Rev 1207.

Flaspohler, Frank “All who live in love” (2009) 11 Loy J Pub Int L 87 at 90-91.

Golash, Deirdre "Marriage, Autonomy, and the State: Reply to Christopher Bennett" (2006) 12 Res Publica 179. 
Grainer, Virginia “Is Family Protection a Question of Moral Duty?” (1994) 24 VUWLR 141.

Graycar, Reg and Millbank, Jenni "From Functional Family to Spinster Sisters: Australia's Distinctive Path to Relationship Recognition" (2007) 24 JL and Pol'y 121.

Graycar, Reg and Millbank, Jenni "The Bride Wore Pink ... To the Property (Relationships) Legislation Amendment Act 1999: Relationships Law Reform in New South Wales" (2000) 17 Can J Fam L 227.

Hamilton, Vivian E "Family Structure, Children, and Law" (2007) 24 Wash U J L \& Pol'y 9.

Harder, Lois "The State and the Friendships of the Nation: The Case of Nonconjugal Relationships in the United States and Canada" (2009) 34 Signs Journal of Women in Culture and Society 634.

Higgens, Darryl "Families caring: Diverse care work of families in Australia" (2007) 76 Family Matters 1.

Houlgate, Laurence "What is legal intervention in the family? Family law and family privacy" (1998) 17 Law and Phil 141.

Jefferson, Simon "De facto or 'friends with benefits'?" (2007) 12 NZ Family Law Journal 304.

Jorgensen, Diane; Parsons, Matthew; Jacobs, Stephen and Arksey, Hilary "The New Zealand informal caregivers and their unmet legal needs" (2010) 123 New Zealand Medical Journal 1317.

Karst, Kenneth L "The Freedom of Intimate Association" (1980) 89 Yale LJ 624.

La Violette, Nicole "Waiting in a New Line at City Hall: Registered Partnerships as an Option for Relationship Recognition Reform in Canada" (2002) 19 Can J Fam L 115.

McK Norrie, Kenneth "Inheritance tax, civil parntership and the rights of spinster sisters" (2008) 12 Edinburgh LR 1364.

Millbank, Jenni "Domestic Rifts: Who is Using the Domestic Relationships Act 1994 (ACT)?” (2000) 14 AJFL 1.

Musselman, James L "What's Love Got to Do With It? A proposal for elevating the status of marriage by narrowing its definition, while universally extending the right and benefits enjoyed by married couples" (2009) Duke J of Gender L \& Pol'y 37. 
Leib, Ethan J "Friendship \& the Law" (2006-7) 54 UCLA L Rev 631.

Parker, Robyn "Perspectives on the future of marriage" (2005) 72 Family

Matters 78.

Polikoff, Nancy "We Will Get What We Ask For: Why Legalizing Gay and Lesbian Marriage Will Not Dismantle the Legal Structure of Gender in Every Marriage" (1993) 79 Va L Rev 1535.

Rosenbury, Laura A (2007) "Friends with benefits? (family law doctrine)" 106 Mich L Rev 189.

Santos, Ana Cristina "Sexual Orientation In Portugal: Towards Emancipation" (2004) 9 South Euro Science \& Pol 159.

Sarantakos, Sotirios "Legal Recognition of Same-Sex Relationships" (1998) 23 Alt LJ 222.

Sutton, Richard and Peart, Nicola "Testamentary Claims by Adult Children The Agony of the "Wise and Just Testator" (2003) 10 Otago LR 385.

Thomas, Caroline A "the Roles of Registered Partnerships and Conjugality in Canadian Family Law” (2006) 22 CJFL 223.

Thomas G Anderson "Comment on the Report of the British Columbia Law Institute on Recognition of Spousal and Family Status" (2000) 12 CJWL 439.

Wilson, J G, Calsyn, R J \& Orlofsky J L "Impact of sibling relationships on social support and morale" (1994) 22 Journal of Gerontological Social Work 157.

Wilson, Robin Fretwell "Evaluating marriage: does marriage matter to the nuturing of children? (Symposium: The Meaning of Marriage)" (2005) 42 San Diego L Rev 847.

\section{Reports}

ACT Department of Justice and Community Safety The Recognition of Same Sex Relationships in ACT (2005).

Alberta Law Reform Institute Family Law Project: Spousal Support (DP 18.2, 1998).

Alberta Law Reform Institute Recognition of Rights and Obligations in SameSex Relationships (RP 21, 2002).

British Columbia Law Institute Report on Recognition of Spousal and Family Status (1999). 
Families Commission Family Centred Communities (2009).

Hawaii State Auditor Study of the Fiscal Impact of Providing Certain Benefits to Reciprocal Beneficiaries R 99-17 (1999).

Jacobsen, veronica; Fursman, Lindy; Bryant, John; Claridge, Megan; and Jensen, Benedikte "Theories of the Family and Policy" (Treasury Working Paper 02/04, 2004).

Law Commission Intestacy and Family Provision Claims on Death (CP 191, 2009).

Law Commission Justice: The Experiences of Māori Women (NZLC R 53, 1999).

Law Commission Succession (NZLC R 41, 1997).

Law Commission The Future of the Joint Family Homes Act (NZLC PP 44, 2001).

Law Commission The Future of the Joint Family Homes Act (NZLC R 77, 2001).

Law Commission of Canada Beyond Conjugality: Recognizing and supporting close personal adult relationships (2001).

Law Commission of England Sharing Homes: A Discussion Paper (2002).

Lesbian and Gay Legal Rights Service "The Bride Wore Pink” (1993).

Lesbian and Gay Legal Rights Service “The Bride Wore Pink” (2 ${ }^{\text {nd }}$ ed, 1994).

Ministry of Social Development The Social Report (2009).

New South Wales Law Reform Commission De Facto Relationships (NSWLRC R 36, 1983).

New South Wales Law Reform Commission Relationships (NSWLRC 113, 2006).

New South Wales Law Reform Commission Review of the Property (Relationships) Act 1994 (NSW) (NSWLRC DP 44, 2002).

Office of the Deputy Prime Minister State of the English Cities (2006).

Ontario Human Rights Commission The Cost of Caring: Report on the Consultation on Discrimination on the Basis of Family Status (2006). 
Parliament of Tasmania: Joint Standing Committee on Community Development Report on the Legal Recognition of Significant Personal Relationships (2001).

Scrutiny of Acts and Regulations Committee Alert Digest No 15 of 2008 (2008).

South African Law Reform Commission Domestic Partnerships (DP 104, 2003).

United Nations Human Rights Committee General Comment No 28, Equality of rights between men and women (Article 3) CCPR (29 March 2000).

Vermont Civil Union Review Commission Report of the Vermont Civil Union Review Commission (2001).

Vermont Civil Union Review Commission Report of the Vermont Civil Union Review Commission (2002).

Working Group on Domestic Partnership Options Paper (November 2006).

\section{Unpublished papers and lectures}

Barker, Nicola. "Beyond (Same-Sex) Marriage and Beyond Conjugality: "Spinster Sisters" and the Recognition of Non-Sexual Relationships in Hawaii, Tasmania, and the UK" (Annual Meeting of the Law and Society Association, Montreal, 29 May 2008).

Davies, Christine "The Extension of Marriage-Like Rights and Obligations Beyond Conjugality: The Adult Interdependent Relationships Act of Alberta" (Conference of the International Society of Family Law, June 2003).

Deech of Cumnor, Baroness "Sisters, sisters, there were never such devoted sisters" (Gresham College, 2 February 2010).

Knight, Dean R "State of the (Civil) Union: Assessing the Legal Significance of the Civil Union Act 2004 and Relationships Bill 2005" (paper presented to Lesbian and Gay Archives New Zealand Conference, Wellington, December 2006).

Tipping, Andrew, Judge of the Supreme Court of New Zealand "Sea of Changes in New Zealand Couples' Property Rights" (Freshfields Bruckhaus Deringer, 16 May 2002).

\section{Parliamentary debates}

(22 April 2004) 662 GBPD HL.

(12 October 2004) 425 GBPD HC. 
(26 May 1999) NSWPD.

19 May 1994) ACTPD.

(21 April 1994) ACTPD.

(6 December 2007) VPD 4393.

\section{Newspaper articles}

AFP/SBS “Rudd rules out gay marriage” SBS (Sydney, 29 July 2009).

"Australian government to block gay civil unions" New Zealand Herald (Auckland, 30 March 2006).

Hon Peter Dunne "Government Signals Repeal of Gift Duty" (press release, 14 June 2010).

Hughes, Kate "Protect your family from the taxman" The Independent (London, 4 May 2008).

Kurtz, Stanley "Here Comes the Brides: Plural marriage is waiting in the wings" The Weekly Standard (26 December 2005).

Q\&A: The Burdens' inheritance tax" BBC News (London, 29 April 2008).

"Relationship register productive: Rudd" Sydney Morning Herald (Sydney, 16 December 2007).

Tempest, Matthew "Lords set back civil partnership bill" The Guardian (24 June 2004).

\section{Websites}

Australian Attorney-General's Department <www.ag.gov.au>

New Zealand Census <www.census.govt.nz>

Oxford English Dictionary Online <oed.com>.

Statistics New Zealand $<$ stats.govt.nz $>$. 


\section{Table of Cases}

\section{New Zealand}

Atkinson v Ministry of Health (2010) 8 HRNZ 902.

D v P FC Wellington FAM-2008-085-238, 24 April 2008.

$G v G$ HC Wellington M682/85, 2 November 1987.

Horsfield v Giltrap [2001] BCL 656.

Quilterv Attorney-General [1998] 1 NZLR 523.

Re AMM \& KJO HC Wellington CIV 2010-485-328, 17 May 2010.

Re Welch [1990] 3 NZLR 1.

$R D P v F M N[2006]$ NZFLR 573.

Riddles v Jones (High Court, Nelson, CP 39/88, 20 June 1990).

Ruka v Department of Social Welfare [1997] 1 NZLR 154.

Samuels v Atkinson [2009] NZCA 556.

Tickner $v$ Wheeler (1985) 3 NZFLR 782.

Thompson v DSW [1994] 2 NZLR 369 at 374.

\section{Overseas}

Burden v United Kingdom (2006) 21 BHRC 640 (Section IV, ECHR).

Burden v United Kingdom (2008) 47 EHRR 857 (Grand Chamber, ECHR).

Farewell v Keaton 240 NW 2d 217.

$M v H[1999] 2$ SCR 3.

Miron v Trudel [1995] 2 SCR 418.

Re Land (deceased) [2007] 1 All ER 324. 


\section{Table of Statutes}

\section{New Zealand}

Accident Compensation Corporation Act 2001.

Administration Act 1969.

Alcoholism and Drug Addiction Act 1966.

Burial and Cremation Act 1964.

Children, Young Persons and Their Families Act 1989.

Civil Union Act 2004.

Credit Contracts and Consumer Finance Act 2003.

Disabled Persons Community Welfare Act 1975.

Domestic Protection Act 1982.

Domestic Violence Act 1995.

Estate Duty Abolition Act 1993.

Family Proceedings Act 1980.

Family Protection Act 1955.

Harassment Act 1997.

Holidays Act 2003.

Human Rights Act 1993.

Income Tax Act 2007.

Interpretation Act 1999.

Joint Homes Act 2003.

Marriage Act 1955.

New Zealand Bill of Rights Act 1990.

Property (Relationships) Act 1976. 
Protection of Personal and Property Rights Act 1988.

Relationships (Statutory References) Act 2005.

Social Security Act 1938.

Social Security Act 1964.

Tax Administration Act 1994.

\section{Overseas}

Adult Interdependent Relationships Act 2002 (Alberta).

Canada Act 1982.

Commonwealth of Australia Constitution Act 1900.

Constitution Act 1867 (Canada).

Customary Marriages Act 1998 (South Africa).

Defense of Marriage Act 1996 (US).

Domestic Relations Act 2009 (Vermont).

Domestic Relationships Act 1994 (ACT).

European Convention for the Protection of Human Rights and Fundamental Freedoms.

Family Services Act 1980 (New Brunswick).

Inheritance Tax Act 1984 (UK).

Marriage Act 1961 (Australia).

Property (Relationships) Act 1984 (NSW).

Relationships Act 2003 (Tasmania).

Reciprocal Beneficiaries Act 1997 (Hawaii).

Relationships (Consequential Amendments) Bill (Tasmania).

The Universal Declaration of Human Rights. 